UNIVERSIDADE DE BRASÍLIA

FACULDADE DE AGRONOMIA E MEDICINA VETERINÁRIA PROGRAMA DE PÓS-GRADUAÇÃO EM AGRONOMIA

DESEMPENHO AGRONÔMICO DE PLANTAS COM DUPLO PROPÓSITO (COBERTURA E GRÃOS) SUBMETIDAS A REGIMES HÍDRICOS VARIÁVEIS E SUA INFLUÊNCIA NOS ATRIBUTOS DO SOLO E NO MILHO EM SUCESSÃO.

ALBERTO DO NASCIMENTO SILVA

DISSERTAÇÃO DE MESTRADO EM AGRONOMIA

BRASÍLIA/DF

$02 / 2017$ 


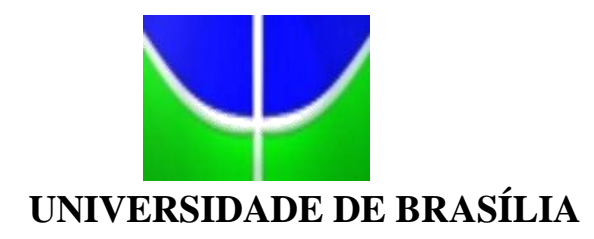

FACULDADE DE AGRONOMIA E MEDICINA VETERINÁRIA PROGRAMA DE PÓS-GRADUAÇÃO EM AGRONOMIA

DESEMPENHO AGRONÔMICO DE PLANTAS COM DUPLO PROPÓSITO (COBERTURA E GRÃOS) SUBMETIDAS A REGIMES HÍDRICOS VARIÁVEIS E SUA INFLUÊNCIA NOS ATRIBUTOS DO SOLO E NO MILHO EM SUCESSÃO.

ALBERTO DO NASCIMENTO SILVA

ORIENTADOR: MARIA LUCRÉCIA GEROSA RAMOS CO-ORIENTADOR: WALTER QUADROS RIBEIJO JUNIOR

DISSERTAÇÃO DE MESTRADO EM AGRONOMIA

PUBLICAÇÃO: 123/17

BRASÍLIA/DF

$02 / 2017$ 


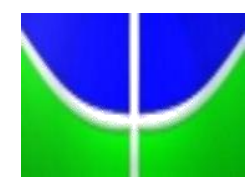

UNIVERSIDADE DE BRASÍLIA

FACULDADE DE AGRONOMIA E MEDICINA VETERINÁRIA PROGRAMA DE PÓS-GRADUAÇÃO EM AGRONOMIA

\section{DESEMPENHO AGRONÔMICO DE PLANTAS COM DUPLO PROPÓSITO (COBERTURA E GRÃOS) SUBMETIDAS A REGIMES HÍDRICOS VARIÁVEIS E SUA INFLUÊNCIA NOS ATRIBUTOS DO SOLO E NO MILHO EM SUCESSÃO}

\section{ALBERTO DO NASCIMENTO SILVA}

DISSERTAÇÃO DE MESTRADO SUBMETIDA AO PROGRAMA DE PÓSGRADUAÇÃ̃O EM AGRONOMIA, COMO PARTE DOS REQUISITOS NECESSÁRIOS À OBTENÇÃO DO GRAU DE MESTRE/DOUTOR EM AGRONOMIA.

APROVADA POR:

MARIA LUCRECIA GEROSA RAMOS, PhD/FAV-UnB/ (Orientadora) CPF 00209443812, email-lucreciaunb@gmail.com

ALESSANDRA MONTEIRO DE PAULA, Dra /FAV-UnB/ (Membro interno) CPF 820.032.201-78, e-mail- alessandramp@unb.br

CRISTIANE ANDREA DE LIMA, Dra/FAV-UnB/ (Membro externo) CPF 00711761108, e-mail-agro.cristiane@gmail.com 


\section{FICHA CATALOGRÁFICA}

\section{SILVA, Alberto do Nascimento}

Desempenho agronômico de plantas com duplo propósito (cobertura e grãos) submetidas a regimes hídricos variáveis e sua influência nos atributos do solo e no milho em sucessão. / Orientação: Maria Lucrécia Gerosa Ramos. - Brasília, 2017. 103 p. : il.

Dissertação de Mestrado (M) - Universidade de Brasília/Faculdade de Agronomia e Medicina Veterinária, 2017.

1 Plantas de cobertura. 2 Zea mays. 3 carbono orgânico. 4 disponibilidade hídrica.

I. Ramos, M.L.G. II. D.Sc.

CDD ou CDU

Agris / FAO

\section{REFERÊNCIA BIBLIOGRÁFICA}

SILVA, A. N. Desempenho agronômico de plantas com duplo propósito (cobertura e grãos) submetidas a regimes hídricos variáveis e sua influência nos atributos do solo e no milho em sucessão. Brasília: Faculdade de Agronomia e Medicina Veterinária, Universidade de Brasília, 2017, 103 p. Dissertação de Mestrado.

\section{CESSÃO DE DIREITOS}

NOME DO AUTOR: ALBERTO DO NASCIMENTO SILVA

TÍTULO DA DISSERTAÇÃO: Desempenho agronômico de plantas com duplo propósito (cobertura e grãos) submetidas a regimes hídricos variáveis e sua influência nos atributos do solo e no milho em sucessão.

GRAU: Mestre

ANO: 2017

É concedida à Universidade de Brasília permissão para reproduzir cópias desta dissertação de mestrado para única e exclusivamente propósitos acadêmicos e científicos. $\mathrm{O}$ autor reserva para si os outros direitos autorais, de publicação. Nenhuma parte desta dissertação de mestrado pode ser reproduzida sem a autorização por escrito do autor. Citações são estimuladas, desde que citada à fonte.

Nome: ALBERTO DO NASCIMENTO SILVA

CPF: 051.470.305.90

Endereço. SIA, QUADRA 5C, LOTE 01, GUARÁ, DF, BRASIL

Tel. (61) 982634029

Email: albertons28@hotmail.com 
DEDICO,

Aos meus pais, que tanto apoiarame incentivaram $o$ meu crescimento profissional. 


\section{AGRADECIMENTOS}

Inicialmente, agradeço a Deus, por me conceder o dom da vida e por guiar meus passos durante minha caminhada.

À minha família: meus pais, Naldir Carvalho da Silva e Silvio do Nascimento Silva pelo amor dedicado à nossa família, ao meu irmão André Luiz e a minha cunhada Iara Maria, por estarem sempre ao meu lado.

À minha namorada Mirlene Nazareth Ferreira pelo amor, carinho, paciência e compreensão.

À minha orientadora, PhD Maria Lucrécia Gerosa Ramos, por ter acreditado em mim, pela orientação, dedicação, convivência e ensinamentos durante a execução dessa pesquisa.

Ao meu co-orientador $\mathrm{PhD}$ Walter Quadros Ribeiro Junior pelos ensinamentos e disponibilidade em esclarecer todas as dúvidas surgidas ao longo do trabalho.

À toda a equipe da Embrapa Cerrados, Alberto Pires, José Reis, Geraldo e todos os estagiários que contribuíram para a realização desse trabalho.

À pesquisadora $\operatorname{Dr}^{\mathrm{a}}$ Cristiane Andrea de Lima e ao professor do Instituto Federal de Brasília, Dr. Adilson Jayme de Oliveira por todo o apoio, ensinamentos e contribuição para a execução desse trabalho.

A todos os meus amigos que torceram e contribuíram para que eu concluísse com êxito esse desafio. Em especial aos meus amigos do Programa de Pós-graduação e da graduação em agronomia, Jônatas Barros, Daiane Soares, Divina Cleia, Vivian Galdino, Antônio Marcos, Stefany Braz, Daniel Fernandez, Lemerson Brasileiro.

À Faculdade de Agronomia e Medicina Veterinária da Universidade de Brasília e aos seus professores, coordenadores e funcionários, pelas oportunidades.

À Embrapa Cerrados por disponibilizar a estrutura necessária para a realização desse trabalho.

À Capes pela concessão da bolsa de estudos.

Meu muito obrigado a todos! 


\section{SUMÁRIO}

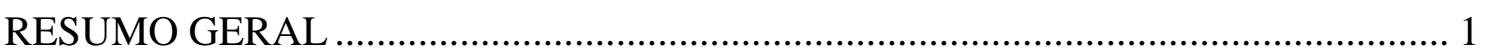

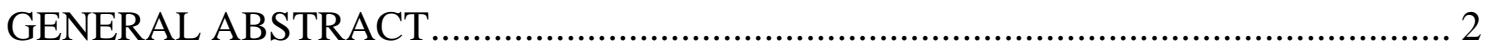

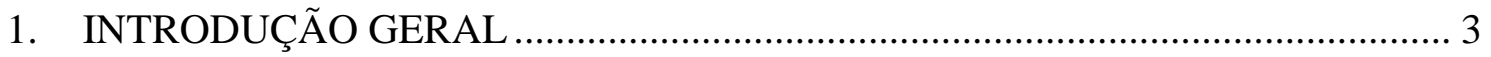

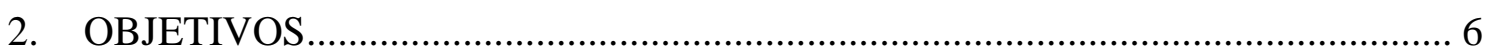

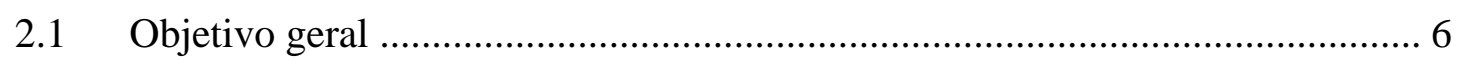

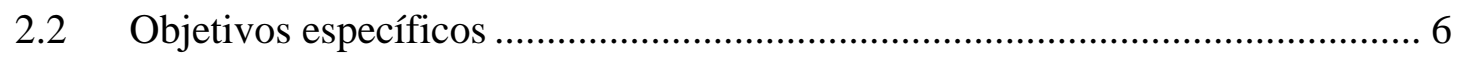

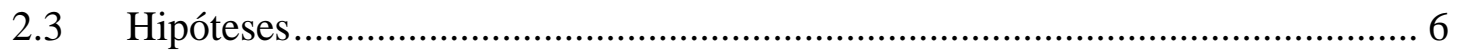

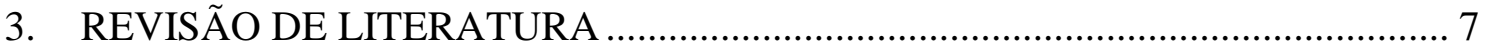

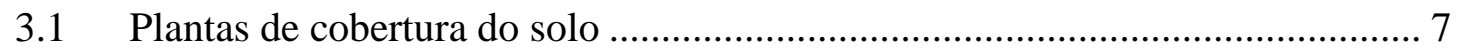

3.2 Disponibilidade hídrica e desenvolvimento das plantas .................................. 8

3.3 Carbono orgânico do solo e suas frações ........................................................ 10

3.4 Influência das plantas de cobertura no carbono orgânico do solo .................... 11

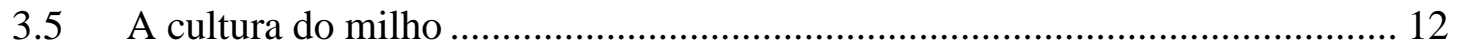

3.6 Influência de plantas de cobertura no milho cultivado em sucessão ................ 15

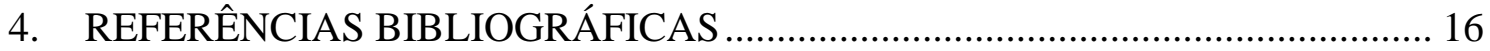

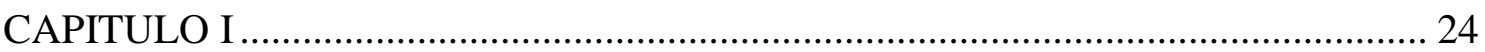

5. DESEMPENHO AGRONÔMICO DE PLANTAS DUPLO PROPÓSITO DE COBERTURA E GRÃOS CULTIVADAS SOB REGIMES HÍDRICOS VARIÁVEIS NO CERRADO BRASILEIRO ........................................................................... 25

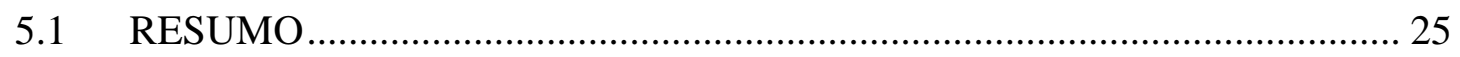

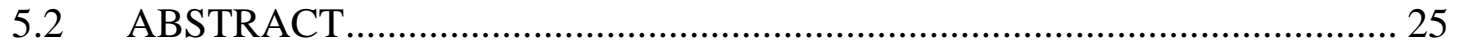

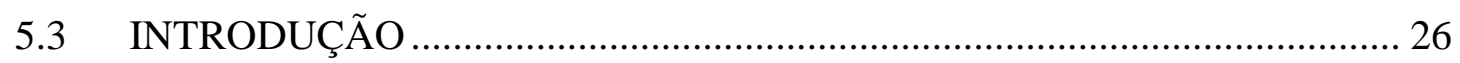

5.4 MATERIAL E MÉTODOS ...................................................................... 28

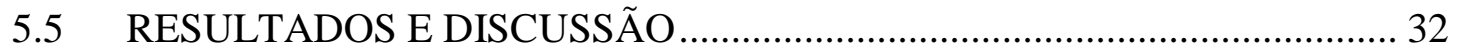

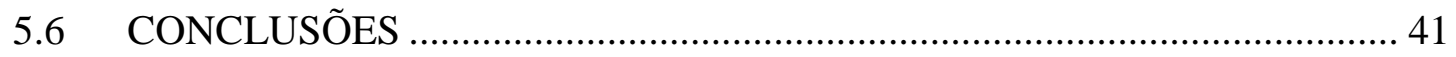

5.7 REFERÊNCIAS BIBLIOGRÁFICAS …............................................... 42

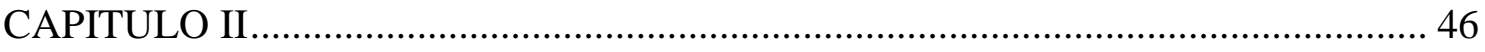

6. INFLUÊNCIA DE PLANTAS DE COBERTURA CULTIVADAS SOB REGIMES HÍDRICOS VARIÁVEIS NOS COMPONENTES MORFOLÓGICOS E

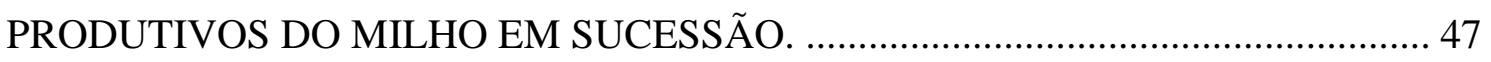

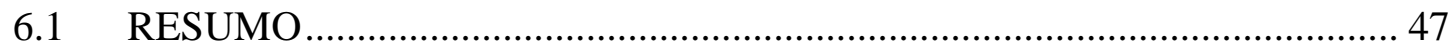




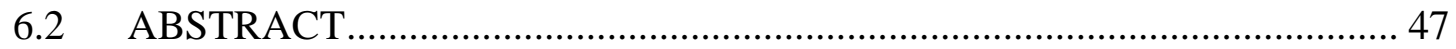

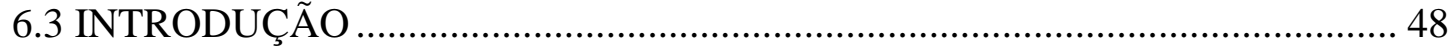

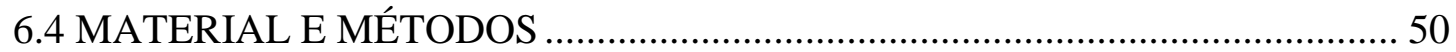

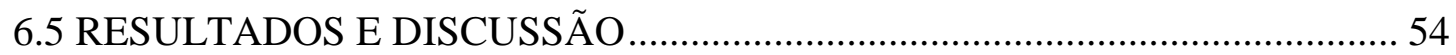

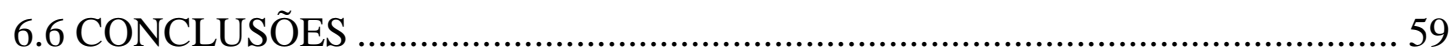

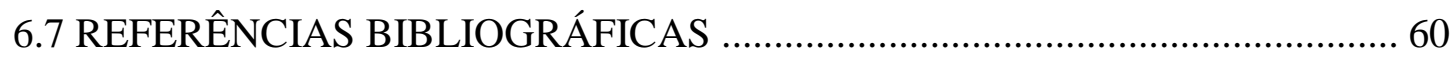

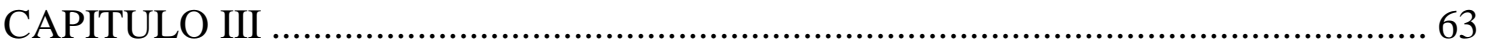

7. INFLUÊNCIA DE PLANTAS DE COBERTURA CULTIVADAS SOB REGIMES HÍDRICOS VARIÁVEIS NAS FRAÇÕES DO CARBONO ORGÂNICO

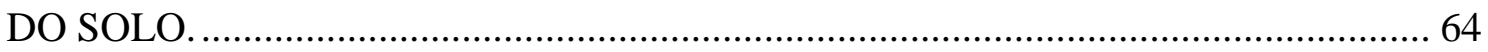

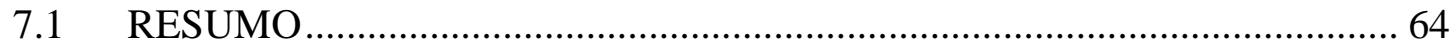

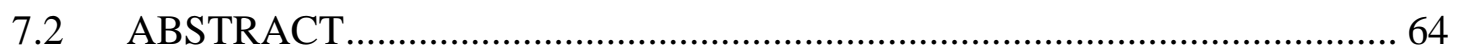

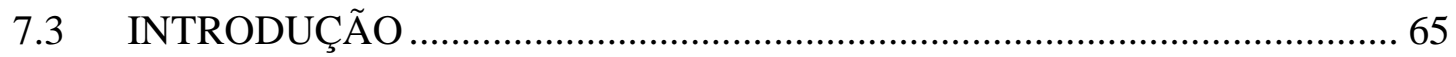

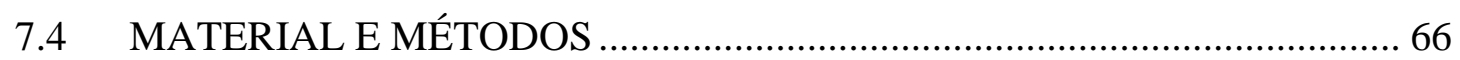

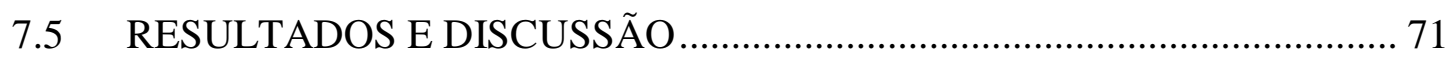

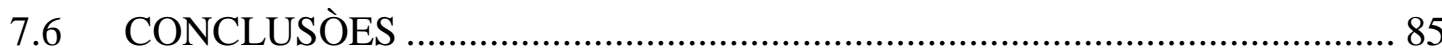

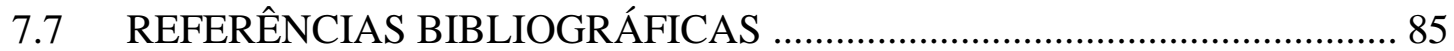




\section{LISTA DE FIGURAS}

Figura 3.1- Evolução da produção e área plantada da cultura do milho no Brasil - Safra 1976/77 a 2014/15.

Figura 3.2- Evolução da produtividade da cultura do milho no Brasil - Safra 1976/77 a $2014 / 15$ .14

Figura 5.1: Precipitação pluviométrica e temperaturas máximas e mínimas ocorridas na área experimental nos meses de maio a outubro de 2015. *Dados obtidos de estação automática localizada próxima à área experimental. .28

Figura 5.2: Médias de biomassa seca $\left(\mathrm{t} \mathrm{ha}^{-1}\right)$ para os fatores planta de cobertura e regime hídrico. Médias seguidas pela mesma letra não diferem entre si, ao nível de $5 \%$ de probabilidade pelo teste de Tukey. 35

Figura 6.1: Precipitação pluviométrica e temperatura média ocorrida nos decêndios compreendidos entre os meses de abril a outubro de 2009 em Planaltina - DF. *Dados obtidos da estação meteorológica localizada ao lado da área experimental. .50

Figura 7.1: Precipitação pluviométrica e temperaturas máximas e mínimas ocorridas na área experimental nos meses de maio a outubro de 2015. *Dados obtidos de estação automática localizada ao lado da área. .68 


\section{LISTA DE TABELAS}

Tabela 5.1: Análise química do solo da área experimental, nas profundidades de 0-10, 10-20, 20-30 cm, realizada em abril/2013

Tabela 5.2: Descrição do histórico de cultivo da área de estudo sob sistema de plantio direto no período compreendido entre 2011 - 2015.

Tabela 5.3: Análise de variância (valores de F) para as variáveis biomassa fresca (BF), biomassa seca (BS), em função dos regimes hídricos e das plantas de cobertura.

Tabela 5.4: Desdobramento da interação significativa entre plantas de cobertura e regime hídrico para produção de biomassa fresca $(\mathrm{BF})$.

Tabela 5.5: Análise de variância (valores de F) para os teores e acúmulo de macro e micronutrientes na parte aérea em função das plantas de cobertura e do regime hídrico.35

Tabela 5.6: Efeito isolado dos fatores plantas de cobertura e regime hídrico nos teores médios de macro e micronutrientes

Tabela 5.7: Desdobramento da interação de regime hídrico e plantas de cobertura referente ao teor de Boro (B) e Zinco (Zn) na parte aérea das plantas.

Tabela 5.8: Desdobramento da interação do regime hídrico e plantas de cobertura referente ao acúmulo de Fósforo $(\mathrm{P})$, Cálcio $(\mathrm{Ca})$, Boro $(\mathrm{B})$ e Zinco $(\mathrm{Zn})$ na parte aérea das plantas.

Tabela 5.9: Efeito isolado dos fatores plantas de cobertura e do regime hídrico no acúmulo de macro e micronutrientes

Tabela 5.10: Desdobramento da interação do regime hídrico e plantas de cobertura referente a produtividade de grãos

Tabela 6.1: Análise química do solo da área experimental, nas profundidades de 0-10, 10-20, 20-30 cm, realizada em abril/2013.

Tabela 6.2: Descrição do histórico de cultivo da área de estudo sob sistema de plantio direto no período compreendido entre 2011 - 2015

Tabela 6.3: Análise de variância (Valores de F) para a produção de matéria seca e teores de lignina e celulose em função da planta de cobertura e do regime hídrico. .55 
Tabela 6.4: Valores médios da produção de matéria seca e teores de celulose e lignina nas plantas de cobertura.

Tabela 6.5: Valores médios da produção de matéria seca e teores de celulose e lignina em função do regime hídrico

Tabela 6.6: Análise de variância (Valores de F) para os componentes morfológicos do milho.

Tabela 6.7: Valores médios das características morfológicas do milho em função da planta de cobertura antecessora.

Tabela 6.8: Valores médios das características morfológicas do milho em função do regime hídrico aplicado a planta de cobertura antecessora.

Tabela 6.9: Análise de variância (Valores de F) para produtividade de grãos e componentes produtivos do milho

Tabela 6.10: Valores médios da produtividade de grãos e características produtivas do milho em função das plantas de cobertura antecessoras.

Tabela 7.1: Análise química do solo da área experimental, nas profundidades de 0-10, 10-20, 20-30 cm, realizada em abril/2013.

Tabela 7.2: Descrição do histórico de cultivo da área de estudo sob sistema de plantio direto no período compreendido entre 2011 - 2015.

Tabela 7.3: Análise de variância (valores de F) para as variáveis carbono orgânico total, frações húmicas (ácido húmico, ácido fúlvico e humina) e carbono microbiano, em função dos regimes hídricos e das plantas de cobertura.

Tabela 7.4: Efeito da planta de cobertura nos teores de carbono orgânico total nas profundidades de $0-5 \mathrm{~cm}, 5-10$ e $10-20 \mathrm{~cm}$.

Tabela 7.5: Efeito do fator regime hídrico nos teores de carbono orgânico total nas profundidades de $0-5 \mathrm{~cm}, 5-10$ e $10-20 \mathrm{~cm}$

Tabela 7.6: Desdobramento da interação entre regime hídrico e plantas de cobertura referente aos teores de ácido húmico $\left(\mathrm{g} \mathrm{kg}^{-1}\right)$ nas profundidades de $0-5$ e $5-10 \mathrm{~cm} . . .76$

Tabela 7.7: Efeito do regime hídrico e da planta de cobertura nos teores de ácido húmico $\left(\mathrm{g} \mathrm{kg}^{-1}\right)$ na profundidade de $10-20 \mathrm{~cm}$

Tabela 7.8: Desdobramento da interação da relação percentual (\%) entre carbono da fração ácido húmico e carbono orgânico total em função da planta de cobertura e do regime hídrico, nas profundidades de 0-5, 5-10 e 10-20 cm. .77 
Tabela 7.9: Desdobramento da interação entre regime hídrico e plantas de cobertura referente aos teores de ácido fúlvico $\left(\mathrm{g} \mathrm{kg}^{-1}\right)$ nas profundidades de $0-5$ e 5 - 10 e 10 $20 \mathrm{~cm}$.

Tabela 7.10: Relação percentual (\%) entre carbono da fração ácido fúlvico e carbono orgânico total em função da planta de cobertura, nas profundidades de 0-5. .80

Tabela 7.11: Desdobramento da interação da relação percentual (\%) entre carbono da fração ácido fúlvico e carbono orgânico total em função da planta de cobertura e do regime hídrico, nas profundidades de 5-10 e 10-20 cm. .80

Tabela 7.12: Efeito isolado do fator regime hídrico nos teores de humina $\left(\mathrm{g} \mathrm{kg}^{-1}\right)$ na profundidade de $0-5 \mathrm{~cm}$.

Tabela 7.13: Desdobramento da interação entre regime hídrico e plantas de cobertura referente aos teores de humina $\left(\mathrm{g} \mathrm{kg}^{-1}\right)$ nas profundidades de $5-10$ e $10-20 \mathrm{~cm}$

Tabela 7.14: Desdobramento da interação da relação percentual (\%) entre carbono da fração humina e carbono orgânico total em função da planta de cobertura e do regime hídrico, nas profundidades de $0-5 \mathrm{~cm}$

Tabela 7.15: Relação percentual (\%) entre carbono da fração humina e carbono orgânico total em função da planta de cobertura e do regime hídrico, nas profundidades de $0-5 . .83$

Tabela 7.16: Desdobramento da interação entre regime hídrico e plantas de cobertura referente ao carbono da biomassa microbiana ( $\mathrm{mg} \mathrm{kg}^{-1}$ de solo) nas profundidades de 0 5 e $5-10$ e $10-20 \mathrm{~cm}$

Tabela 7.17: Desdobramento da interação da relação percentual (\%) entre carbono da biomassa microbiana e carbono orgânico total em função da planta de cobertura e do regime hídrico, nas profundidades de $0-5 \mathrm{~cm}$ 


\section{RESUMO GERAL}

O presente trabalho teve como objetivo avaliar o desempenho de duas espécies com potencial para cobertura do solo, comparadas com uma espécie tradicional, cultivadas sob regimes hídricos variáveis e sua influência nos atributos do solo e na cultura do milho semeado em sucessão. O experimento foi desenvolvido em condições de campo, de maio de 2015 a março de 2016, na área experimental da Embrapa Cerrados, localizada no município de Planaltina - DF. Os tratamentos foram dispostos em blocos casualizados, com parcelas subdivididas e quatro repetições. As parcelas foram compostas por quatro regimes hídricos ( $167 \mathrm{~mm} ; 268 \mathrm{~mm} ; 381 \mathrm{~mm} ; 432 \mathrm{~mm}$ ) e as subparcelas foram compostas pelas seguintes plantas de cobertura: amaranto "BRS Alegria" (Amaranthus cruentus), quinoa, "Genótipo derivado do BRS Piabiru" (Chenopodium quinoa, Wild) e milheto (Pennisetum glaucum). Após o corte das plantas de cobertura foi implantada a cultura do milho (híbrido 2B707Hx) em sucessão. Foram avaliados a produção de biomassa fresca (BF) e seca (BS), os teores e acúmulo de macro e micronutrientes na parte aérea, os teores de celulose e lignina e a produtividade de grãos das plantas de cobertura; os componentes morfológicos do milho (altura de planta, altura de inserção de espiga e diâmetro de colmo), os componentes produtivos (número de fileira de grãos na espiga, número de grãos por espiga, peso médio de espiga, diâmetro de espiga) e a produtividade de grãos. Na floração das plantas de cobertura, foram avaliados os seguintes atributos do solo: carbono orgânico total (COT), carbono das frações húmicas (ácido húmico - C- $\mathrm{AH}$; ácido fúlvico C-AF e humina C-HUM) e o carbono da biomassa microbiana (C-mic) nas camadas de 0-5, 5-10 e 10-20 cm do solo. Em condições de adequado suprimento de água (381; $432 \mathrm{~mm})$, o amaranto apresentou a maior produção de biomassa fresca. De maneira geral, o amaranto foi a espécie com maior teor e acúmulo de macro e micronutrientes e o milheto foi a espécie que apresentou os menores acúmulos. Os regimes hídricos influenciaram a produção de matéria seca e os teores de lignina na parte aérea das plantas de cobertura. $\mathrm{O}$ regime hídrico aplicado às plantas de cobertura, bem como as diferentes espécies de plantas de cobertura, influenciou os atributos morfológicos (altura de plantas, altura de inserção de espiga e diâmetro de colmo) e alguns dos componentes produtivos (diâmetro de espiga e número de grãos por fileira) do milho cultivado em sucessão. As plantas de cobertura promoveram efeito semelhante na produtividade do milho em sucessão. O solo cultivado com milheto apresentou os maiores teores de COT e as plantas de cobertura cultivadas em condições de maior disponibilidade hídrica propiciaram aumento nos teores de $\mathrm{C}$ das frações ácido húmico e ácido fúlvico. $\mathrm{O}$ aumento da disponibilidade hídrica promoveu aumento e reduções no carbono microbiano nas três camadas de solo, dependendo da espécie utilizada.

Palavras - chave: plantas de cobertura, Zea mays, carbono orgânico, disponibilidade hídrica 


\section{GENERAL ABSTRACT}

The objective of this work was to evaluate the performance of two species with potential for cover plants, compared to a traditional species, cultivated under variable water regimes and their influence on the soil attributes and corn cultivated in succession. The experiment was carried out under field conditions, from May, 2015 to March 2016, at the experimental area of Embrapa Cerrados, located in the city of Planaltina - DF. The treatments were design in randomized blocks, with subplots and four replications. Plots were composed of four water regimes (167 mm; $268 \mathrm{~mm} ; 381 \mathrm{~mm} ; 432 \mathrm{~mm})$ and subplots were composed of three cover crops (Amarantous cruentus), quinoa, "Genotype derived from BRS Piabiru" (Chenopodium quinoa, Wild) and millet (Pennisetum glaucum). After the cutting of the cover plants, corn $(2 \mathrm{~B} 707 \mathrm{Hx}$ hybrid) was sown in succession. Shoot fresh weight (SFW) and shoot dry weight (SDW) and plant nutrient content and grain yield and cellulose and lignin contents of the cover plants were evaluated. Also, the corn morphological components (plant height, spike insertion height and stalk diameter), the productive components (row number of grains on the spike, number of grains per spike, weight of a thousand grains, average ear weight, diameter of spike) and corn grain yield in succession were evaluated. At cover plants flowering, the following soil attributes were evaluated: total organic carbon (TOC), humic fractions carbon (humic acid $(\mathrm{C}-\mathrm{H}), \mathrm{C}-\mathrm{AF}$ fulvic acid and C-HUM humin) and microbial biomass carbon (C-mic) in the layers 0-5, 5-10 and 10-20 cm. Under adequate conditions of water supply, amaranth presents a higher production of fresh biomass. In general, amaranth was a species with higher content and accumulation of macro and micronutrients and corn for a species that presented the smallest accumulations. The water regimes influenced dry matter production and lignin contents in the aerial part of the cover plants. The water regime applied to the cover plants, as well as the different species of cover plants, influenced the morphological attributes and some of the productive components (spike diameter and number of plants). Grains per row of maize grown in succession. Cover plants promoted a similar effect on maize productivity in succession. The soil cultivated with millet showed the highest TOC contents and the cover crops grown under conditions of higher water availability resulted in an increase in the $\mathrm{C}$ content of humic acid and fulvic acid fractions. The increase in water availability promoted increase and reductions in microbial carbon in the three soil layers, depending on the species used.

Keywords: cover crops, Zea mays, organic carbon, water availability 


\section{INTRODUÇÃO GERAL}

A utilização e ocupação agrícola da região do Cerrado vêm ocorrendo com necessidade de adoção de novas tecnologias fundamentadas em bases conservacionistas (Boer et al., 2007). Portanto, é fundamental um adequado manejo do solo, com uso de práticas conservacionistas mecânicas, edáficas e vegetativas, entre as quais se destaca o uso de plantas de cobertura (Carvalho et al. 2013; Carvalho et al., 2015). A implantação de espécies de plantas para cobertura e a manutenção de seus restos culturais na superfície do solo são fundamentais para promover melhorias dos atributos físicos e químicos, aumentar a atividade microbiana, o acúmulo de nutrientes e manter os teores de matéria orgânica nas camadas superficiais (Casali, 2012; Lima Filho et al.,2014), e promover maiores rendimentos dos cultivos agrícolas plantados em sucessão.

Do ponto de vista dos atributos biológicos, o uso de plantas de cobertura afeta as diferentes populações de organismos constituintes da biota do solo, uma vez que cria micro habitats favoráveis a estes, além do fato dos resíduos vegetais servirem como fonte de nutrientes e energia (Merlin et al., 2005). Vários trabalhos têm evidenciado o efeito benéfico das plantas de coberturas nos atributos biológicos do solo, como a biomassa microbiana (Araujo Neto et al., 2014; Duarte et al., 2014; Loureiro et al., 2016; Coser et al., 2016). O uso de plantas de cobertura também pode acarretar aumento nos teores de carbono orgânico total e nas frações húmicas da matéria orgânica do solo. (Pereira et al., 2010; Guimarães et al., 2013)

Com relação ao efeito de plantas de cobertura no rendimento de culturas subsequentes, alguns estudos na região do Cerrado têm demonstrado o efeito benéfico das plantas de cobertura antecedendo as culturas comerciais (Torres et al., 2013; Torres et al., 2014; Cardoso et al., 2014; Carvalho et al., 2015). Tal fato pode ser atribuído â contínua liberação de nutrientes na superfície do solo após a decomposição dos seus resíduos vegetais (Pacheco et al., 2011; Carvalho et al., 2015) e por incrementar os teores de matéria orgânica, além de reduzir as variações de temperatura e evaporação da água do solo e manter o solo mais úmido, fatores que favorecem os cultivos subsequentes (Boer et al., 2008). Segundo Assis et al. (2013), o uso de plantas de cobertura adaptadas as condições edafoclimáticas do Cerrado e a manutenção dos resíduos culturais na superfície do solo é uma importante alternativa para aumentar a sustentabilidade dos sistemas agrícolas. Essas plantas destacam-se pelo crescimento regular ativo e contínuo do sistema 
radicular, elevada capacidade de produção de biomassa e absorção de nutrientes de camadas subsuperficiais (Junior Ramos et al., 2013).

A eficácia do sistema plantio direto está relacionada, entre outros fatores, à qualidade e quantidade dos resíduos culturais (Pires et al., 2008). Em relação à qualidade, características como relação C/N e teor de lignina (Espindola et al., 2006; Carvalho et al., 2008; Carvalho et al., 2009; Acosta et al., 2014; Carvalho et al., 2015) são fatores importantes na formação e manutenção de palhada no solo. Quanto à quantidade, a produção de matéria seca das espécies utilizadas para cobertura do solo depende das condições edáficas, práticas sanitárias, manejo e principalmente da disponibilidade hídrica para a planta durante o seu ciclo. Na região Centro-Oeste do Brasil, a produção e manutenção da cobertura vegetal na superfície do solo é um desafio, devido ao inverno seco, que limita o cultivo nessa época e ao verão quente e chuvoso, que acelera a decomposição da palhada (Leite et al., 2010; Silva et al., 2010).

O uso de espécies com decomposição mais lenta representa uma estratégia para aumentar a eficiência na produção e manutenção de resíduos sobre a superfícies do solo (Bressan et al., 2013). Portanto, o desafio a ser vencido na implantação do sistema de semeadura direta em regiões tropicais, onde a ocorrência de invernos secos é uma constante, diz respeito à obtenção de plantas adaptadas a essas condições, capazes de produzir suficiente quantidade de cobertura vegetal em condições de baixa disponibilidade hídrica (Junior Ramos et al.,2013).

Os sistemas de produção podem ser otimizados por meio da utilização de plantas com duplo propósito. A utilização dessas plantas possibilita a produção de biomassa para cobertura do solo e ainda produção de grãos, contribuindo assim para maior estabilidade da produção e otimização do sistema (Wrobel et al., 2016; Meinerz et al., 2012). O Amaranto (Amaranthus cruentus) e a quinoa (Chenopodium quinoa), pertencentes ao grupo dos pseudocereais, apresentam potencial para produção de biomassa e grãos. Os grãos do amaranto possuem alto valor proteico (14-16\%), além de serem ricos em fibras e minerais (Gimplinger et al.,2008). Na região do Cerrado, a produtividade de biomassa seca e de grãos dessa espécie varia de 6,7 a 9,1 t ha-1 e $900 \mathrm{~kg}$ até 3,69 t ha-1, respectivamente, a depender da cultivar e manejo adotado (Erasmo et al., 2004; Ferreira et al., 2014). Os grãos de quinoa apresentam elevado potencial nutricional pelo excelente equilíbrio entre carboidratos, lipídios e proteínas, compostas por aminoácidos essenciais, 
como lisina e metionina, encontrados em quantidades superiores à dos cereais e leguminosas (Valência et al., 2016; Borges et al., 2010). Trabalhos realizados na região do Cerrado obtiveram produtividades de até $7 \mathrm{t} \mathrm{ha}^{-1}$ de biomassa seca (Rocha et al., 2008) e $1,82 \mathrm{t} \mathrm{ha}^{-1}$ de grãos para a quinoa (Silva et al., 2015).

Nesse contexto, a pesquisa deve buscar plantas de cobertura mais adaptadas às diferentes condições edafoclimáticas e que proporcionem melhorias nos atributos do solo, forneçam nutrientes para as culturas semeadas em sucessão, e com elevado potencial de produção de biomassa e grãos, em condições de baixo regime hídrico, para serem utilizadas como novas alternativas no sistema plantio direto na região do Cerrado. 


\section{OBJETIVOS}

\subsection{Objetivo geral}

Avaliar o desempenho de duas espécies com potencial para cobertura do solo, comparadas com uma espécie tradicional, cultivadas sob regimes hídricos variáveis e sua influência nos atributos do solo e na cultura do milho semeado em sucessão.

\subsection{Objetivos específicos}

Quantificar a produção de biomassa aérea verde e seca, produtividade de grãos o teor e acúmulo de nutrientes na matéria seca de Amaranthus cruentus, Chenopodium quinoa em comparação com uma planta de cobertura tradicional (Pennisetum glaucum) sob os regimes hídricos variáveis.

Avaliar a produtividade e os componentes morfológicos e produtivos da cultura do milho cultivado em sucessão a Amaranthus cruentus, Chenopodium quinoa e Pennisetum glaucum, cultivados sob regime hídrico variável.

Quantificar o fracionamento químico da matéria orgânica do solo, após o cultivo de Amaranthus cruentus, Chenopodium quinoa e Pennisetum glaucum sob diferentes regimes hídricos.

\subsection{Hipóteses}

Plantas com potencial para cobertura do solo (quinoa e amaranto) são uma opção adicional ao milheto no Cerrado.

A produtividade de grãos, produção de biomassa aérea, o teor e acúmulo de nutrientes nas plantas de cobertura são influenciados pelos diferentes regimes hídricos aplicados.

As diferentes plantas de coberturas do solo sob diferentes regimes hídricos alteram as frações do carbono orgânico do solo.

A produtividade de grãos e os atributos morfológicos e produtivos do milho cultivado em sucessão são influenciadas pelas diferentes plantas de coberturas do solo. 


\section{REVISÃO DE LITERATURA}

\subsection{Plantas de cobertura do solo}

O uso de plantas de cobertura contribui para a conservação do solo, reduz a erosão e propicia efeitos positivos nas suas propriedades físicas, químicas e biológicas (Barros et al., 2013). Na região do Cerrado, a manutenção de resíduos vegetais para a cobertura do solo tem sido um desafio, devido, principalmente, à baixa produção de fitomassa na entressafra e decomposição acelerada dos resíduos (Carvalho et al., 2008; Carvalho et al., 2009; Bressan et al., 2013; Carvalho et al., 2015). Nesse sentido, a utilização de espécies da família Poaceae, que são plantas com elevada produção de biomassa e resíduos com elevada razão $\mathrm{C} / \mathrm{N}$, pode contribuir para reduzir a taxa de decomposição e promover liberação mais lenta de nutrientes no solo (Silva et al., 2012; Carvalho et al., 2013). Entre as espécies dessa família utilizadas como plantas de cobertura na região do Cerrado, o milheto (Pennisetum glaucum (L) R. Brown) é uma espécie que se destaca (Silva et al., 2010). Tal fato se dá pelo alto acúmulo de matéria seca e macro e micronutrientes, elevada rusticidade da cultura e baixo custo das sementes, podendo apresentar ainda tolerância à seca devido ao sistema radicular bem desenvolvido (Vendrusculo; Nozaski, 2010). O milheto quando semeado no início do período chuvoso produz entre 7 e $12 \mathrm{t} \mathrm{ha}^{-1}$ de matéria seca (Mechede et al., 2007) e em condições de safrinha produz entre 2 e $4 \mathrm{t} \mathrm{ha}^{-1}$ (Teixeira et al., 2010; Carvalho et al., 2015).

O estudo de plantas de cobertura do solo é importante para dispor de novas alternativas para sua utilização no sistema de plantio direto (SPD) e diversificar o sistema produtivo. A baixa diversidade de espécies vegetais possíveis de serem utilizadas nas rotações ocasionam, ao longo do tempo, problemas típicos de monocultivo (Erasmo et al., 2004). O uso de milheto e sorgo em antecipação ou sucessão a culturas comerciais está limitado a um número de espécies de apenas uma família botânica, as gramíneas (Spehar e Lara Cabezas, 2001).

A seleção de novas espécies de plantas de cobertura deve ser realizada com base na sua produção de biomassa, relação C/N (Carvalho et al., 2008), teor de lignina e polifenois (Espindola et al., 2006; Carvalho et al., 2008; Carvalho et al., 2009; Acosta et al., 2014; Carvalho et al., 2015), e na concentração de $\mathrm{N}$ no tecido vegetal (Medrado et al., 2011), essas características afetam a velocidade de decomposição e acúmulo de 
palhada na superfície, e consequentemente o desempenho das mesmas em condições de déficit hídrico (Petter et al., 2013). No entanto, entre as características qualitativas, a relação $\mathrm{C} / \mathrm{N}$ e os teores de lignina e celulose dos resíduos aportados ao solo, assume papel preponderante na decomposição (Acosta et al., 2014).

Uma alternativa para a seleção de plantas de cobertura são os pseudocereais, que tem apresentado boa adaptação à região do Cerrados. Dentre os pseudocereais, a cultura do amaranto (Amaranthus cruentus) possui características bastante promissoras (Ferreira et al., 2014). Essa planta possui raiz pivotante e vigorosa, com abundante ramificação, cria condições favoráveis à absorção de água e nutrientes e por isso tem facilidade de se adaptar a regiões áridas ou em locais com período seco prolongado (Spehar, 2007). Em ensaio para avaliar a produção de Amaranthus spp. no sul do Tocantins, as diferentes cultivares de amaranto produziram matéria seca variando entre 6,7 e 9,1 t ha ${ }^{-1}$ durante a estação chuvosa. Erasmo et al., 2004). Ferreira et al. (2014) ao avaliar o efeito da densidade de semeadura e doses de nitrogênio sobre a produtividade do amaranto na região Centro Oeste observaram matéria seca de folha e caule de até 3,67 $\mathrm{t} \mathrm{ha}^{-1}$. A produção de matéria seca do amaranto chegou a ser maior que a produção do milheto e sorgo em trabalho realizado em Planaltina-DF (Teixeira et al., 2003).

A quinoa (Chenopodium quinoa Willd) é outra espécie caracterizada como pseudocereal que vem apresentando boa adaptação a região do Cerrado. Pela quantidade de biomassa que produz, constitui alternativa para a proteção do solo em plantio direto no Cerrado (Spehar, 1998). É uma espécie que apresenta bom desenvolvimento em condições de limitações ambientais e apresenta estratégias de adaptação ao déficit hídrico, tanto fisiológico como morfológico (SILVA et al., 2014). Em estudos realizados no Brasil, a cultura apresenta capacidade de produzir, em média, $7 \mathrm{t} \mathrm{ha}^{-1}$ de matéria seca (Rocha, 2008).

\subsection{Disponibilidade hídrica e desenvolvimento das plantas}

Os estresses ambientais influenciam o crescimento vegetal e causam menor desempenho das culturas no campo (Carlin e Santos, 2009). Coelho et al., (2010) afirmam que a seca pode ser considerada como o principal estresse ambiental, afetando diretamente a produtividade das culturas em todo o mundo. Na região do Cerrado, devido aos baixos índices pluviométricos na estação seca, um dos desafios a serem vencidos é a 
obtenção de plantas capazes de produzir quantidade suficiente de cobertura vegetal nessa estação (Junior Ramos et al., 2013).

A deficiência hídrica provoca alterações e afeta negativamente o crescimento, desenvolvimento e produção das plantas cultivadas ao longo do seu ciclo. A baixa disponibilidade hídrica tende a provocar modificações morfofisiológicas de defesa, como a redução de trocas gasosas, diminuição de área foliar, redução da taxa fotossintética e aumento da abscisão foliar (Bomfim-Silva et al., 2011; Rodolfo Junior et al., 2016; Cunha et al., 2016). Lima et al., (2015) em estudo sobre atributos fisiológicos e morfológicos de genótipos de trigo, cultivados sob regime hídrico variável, observaram que o estresse hídrico foi o principal fator que reduziu o metabolismo das plantas e reduziu a concentração interna de carbono nas folhas. A baixa disponibilidade hídrica também pode causar a redução no surgimento de novas folhas, alongamento do caule/colmo e o abortamento de botões florais e flores (Smit e Singels, 2006). Em outro trabalho avaliando diferentes genótipos de trigo sob regimes hídricos variáveis na região do Cerrado Lima et al. (2015) atribuíram ao abortamento de flores como um dos fatores responsáveis pela redução na produtividade da cultura.

A irreversibilidade das alterações causadas nas plantas pelo estresse hídrico dependerá da severidade e duração da deficiência hídrica, da espécie cultivada e do seu estágio de desenvolvimento (Santos; Carlesso,1998). As gramíneas, como o sorgo (Sorghum bicolor L. Moench), por exemplo, tem a capacidade de permanecer em estado latente em períodos de déficit hídrico (Paul, 1990). Rodolfo Junior et al., (2016) e Cunha et al., (2016), em estudo sobre características e produtividade da cana de açúcar sob regime hídrico variável, na região Centro Oeste, observaram que o regime hídrico influenciou significativamente no desenvolvimento e produtividade da cultura. Em condições de menor disponibilidade hídrica houve menor crescimento e desenvolvimento da cultura. Bomfim-Silva et al., (2011) e Junior Ramos et al. (2013) estudando o desenvolvimento de gramíneas submetidas ao estresse hídrico observaram que o desenvolvimento do milheto foi influenciado pela disponibilidade de água no solo. Diferentemente do milheto, o sorgo não foi influenciado, evidenciando que as alterações dependem da espécie cultivada. 


\subsection{Carbono orgânico do solo e suas frações}

A matéria orgânica do solo desempenha papel importante na manutenção da produtividade dos solos tropicais. Fornece energia e substratos para a microbiota do solo, promove a diversidade biológica que auxilia na manutenção da qualidade do solo e na funcionalidade dos ecossistemas (Guimarães et al., 2013). É o produto da acumulação de resíduos de plantas e animais parcialmente decompostos e parcialmente ressintetizados e encontra-se na forma de biomassa microbiana, microfauna, substâncias orgânicas solúveis, matéria orgânica estabilizada (substâncias húmicas), etc. (Barreto et al., 2014).

A matéria orgânica do solo é heterogênea e consiste de diferentes frações funcionais e biológicas variando dinâmica e quimicamente (Leite et al., 2015). Essas frações respondem de forma diferenciada ao manejo do solo e as mudanças no uso da terra e podem ser classificadas em lábeis e estáveis (Kelleher et al., 2006).

A fração lábil inclui resíduos vegetais em decomposição, formas solúveis em água, macrofauna edáfica e a biomassa microbiana (Campos et al., 2013). A biomassa microbiana é a fração viva da matéria orgânica do solo e é composta por actinomicetos, bactérias, fungos, protozoários e algas. Essa fração atua no processo de decomposição dos resíduos orgânicos e ciclagem de nutrientes (Cardoso et al; Perez et al, 2004). São frequentes os estudos das frações lábeis da matéria orgânica, como a biomassa microbiana, pois, analises apenas dos estoques de $\mathrm{C}$ orgânico total podem, muitas vezes, não indicar as variações que ocorrem em curto período de tempo (Conte et al., 2011; Souza et al., 2016).

A fração estável, representada pelas substâncias húmicas, representa cerca de 85 a 90\% do carbono total e é constituída pelos ácidos fúlvicos (AF), ácidos húmicos (AH) e humina (HUM) (Guerra et al., 2008; Primo et al., 2011). Essa fração apresenta tempo de permanência no solo que pode chegar a centenas de anos e sua principal função é atuar nas condições físicas e químicas do solo, além de ser importante no sequestro de $\mathrm{C}$ atmosférico (Figueiredo et al., 2010; Silva \& Mendonça, 2007). Solos com maior quantidade de matéria orgânica estável contribuem de maneira significativa para a redução das taxas de emissão de $\mathrm{CO}_{2}$ para a atmosfera (Kragt et al., 2012).

Para a obtenção das frações da matéria orgânica do solo, é necessário utilizar metodologias de fracionamento que tanto pode ser químico como físico (Roscoe e 
Machado, 2002). O fracionamento físico permite a separação de compartimentos orgânicos com diferentes dinâmicas e funções no solo (Moni et al., 2012), possibilitando analisar a relação entre a composição da matéria orgânica e sua localização na estrutura do solo, bem como sua interação com a matriz mineral. $\mathrm{O}$ fracionamento químico permite a separação das substâncias húmicas do solo (Fração estável) com base em sua solubilidade em meio aquoso em três frações: ácido fúlvico (AF), solúvel em pH ácido ou alcalino; ácido húmico $(\mathrm{AH})$, solúvel em pH alcalino e humina (HU), insolúvel em qualquer pH (Santos et al., 2013). Essas diferentes metodologias de fracionamento procuram separar frações homogêneas quanto à natureza, dinâmica e função, mas, que ao mesmo tempo sejam distintas entre si (Christensen, 2000).

\subsection{Influência das plantas de cobertura no carbono orgânico do solo}

A matéria orgânica do solo, em maior ou menor grau, pode sofrer alterações por ser um dos atributos mais sensíveis ao manejo do solo. Dentre os diversos fatores que controlam os teores de matéria orgânica do solo e suas frações, tais como textura, clima, tipo de vegetação, manejo adotado, destaca-se, principalmente, a quantidade e qualidade dos resíduos vegetais depositados na superfície do solo (Vezzani; Mielniczuk, 2009).

As diferentes plantas de cobertura e o manejo do solo influenciam as frações da matéria orgânica. Sistemas de produção com maior aporte de biomassa, o acúmulo de carbono ocorre preferencialmente na fração lábil, a qual é mais sensível do que o carbono orgânico total às alterações no manejo do solo (Rossi et al., 2012).

O sistema de consorciação de culturas, componente básico de um sistema de manejo conservacionista, pode reduzir as perdas de carbono orgânico total (COT) do solo, pela manutenção dos resíduos vegetais na superfície do solo e proteção física da matéria orgânica em agregados do solo (Conceição et al., 2008; Zotarelli et al., 2012). Em estudo para avaliar o carbono e nitrogênio nas frações granulométricas da matéria orgânica Winck et al. (2014) observaram que o número e a sequência de espécies vegetais na rotação de culturas influenciaram significativamente os estoques de $\mathrm{C}$ e $\mathrm{N}$ no solo na camada de $0-5 \mathrm{~cm}$. O sistema plantio direto em razão do não revolvimento do solo e maio aporte de resíduos vegetais promove maior proteção física e manutenção das diferentes frações da matéria orgânica (Winck et al., 2014). 
A biomassa microbiana, componente da fração lábil da matéria orgânica, é fortemente influenciada pelos resíduos vegetais depositados na superfície do solo (Duarte et al., 2014; Loureiro et al., 2016; Coser et al., 2016). Fatores como a composição química (relação $\mathrm{C} / \mathrm{N}$, teores de lignina, celulose e hemicelulose) e a quantidade de resíduo adicionada ao solo influencia o acúmulo de carbono nessa fração (Silva e mendonça, 2007; Zhongkui et al., 2010). Geralmente, resíduos vegetais com decomposição mais lenta proporcionam maior acúmulo da biomassa microbiana por serem fonte de nutrientes aos microrganismos por período mais prolongado (Angers et al., 1993). A maior quantidade de resíduos no solo aumenta a disponibilidade de substrato e determina menor variação térmica e maior disponibilidade de água, favorecendo a biomassa microbiana (Vargas e Scholles, 2000).

As frações húmicas da matéria orgânica também são influenciadas pelo sistema de cultivo implantado. Guimarães et al., (2013) em trabalho avaliando a distribuição das frações húmicas do solo sob diferentes coberturas vegetais, observaram que a distribuição de $\mathrm{C}$ entre as diferentes frações mudou quando solo florestal foi alterado para cultivo, devido a quantidade e qualidade do material adicionado. Dentre as frações húmicas, a humina é a menos propensa a se alterar com as práticas de manejo porque é a mais estável devido a sua insolubilidade e resistência a biodegradação, favorecida pela formação de complexos argilo-humicos estáveis (Grinhut et al., 2007). Alterações nas frações húmicas em virtude do manejo adotado são esperadas, inicialmente, na fração ácido fúlvico, pois esta reflete o primeiro estágio de estabilização da matéria orgânica (Rosa et al., 2017). A fração ácido fúlvico, devido ao seu menor peso molecular e maior densidade de grupamentos carboxílicos apresenta maior solubilidade e polaridade que as demais frações, possuindo então maior mobilidade no solo podendo atingir camadas mais profundas (Silva e Mendonça, 2007).

\subsection{A cultura do milho}

O milho (Zea mays L.) é considerado uma das mais importantes e antigas culturas agrícolas (Alves e Amaral, 2011). Os maiores produtores mundiais são Estados Unidos, China, Brasil, México, Indonésia e Índia, com produção total de aproximadamente 789 milhões de toneladas (FAOSTAT, 2011). O Brasil é o terceiro maior produtor mundial de milho (FAOSTAT, 2012), com cerca de 15,9 milhões de hectares cultivados, sendo 
5,4 e 10,5 milhões de hectares e produtividade de 4.799 e $3.904 \mathrm{Kg} \mathrm{ha}^{-1}$ na primeira e segunda safra, respectivamente $(\mathrm{CONAB}, 2016)$. Aproximadamente, $70 \%$ da produção é destinada ao consumo interno, abastecendo principalmente as atividades de criação de animais e 30\% são destinados as exportações (CONAB, 2014). A cultura do milho tem um alto potencial produtivo, alcançando $10 \mathrm{t} \mathrm{ha}^{-1}$ de grãos em condições experimentais e por agricultores que adotam tecnologia adequada (Carvalho et al., 2004)

Os segmentos que mais consomem milho são a avicultura e a suinocultura com estimativas de consumo na ordem de $43,78 \%$ e $25,07 \%$ da produção nacional, respectivamente (Abimilho, 2011). Ao se observar a evolução da produção e área plantada da cultura (Figura 3.1) nos últimos trinta anos tem-se um aumento considerável desses dois fatores (Conab, 2015). Um dos fatores que determinou esse aumento na produção em grãos foi, principalmente, a demanda interna com o abastecimento das cadeias produtivas da avicultura e suinocultura (Alves e Amaral, 2011).

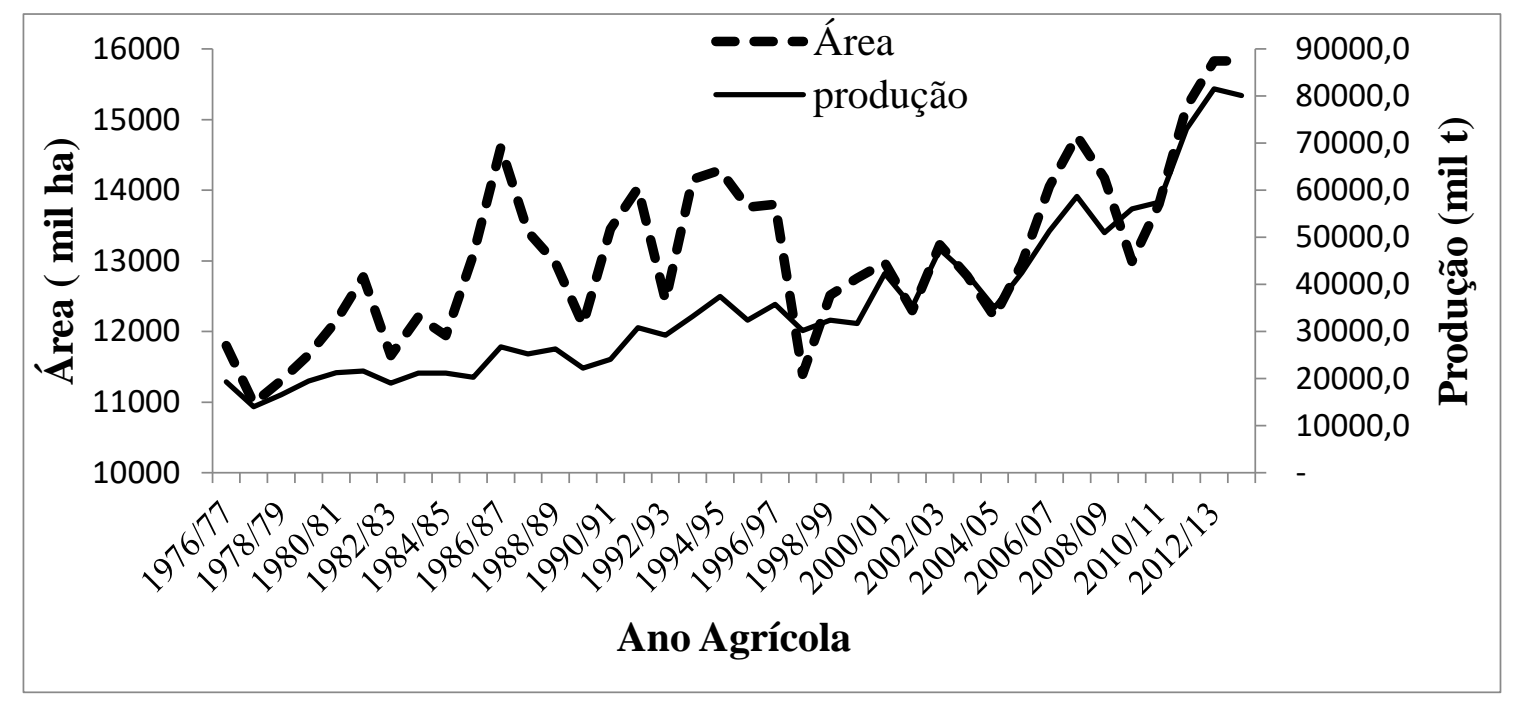

Figura 3.1- Evolução da produção e área plantada da cultura do milho no Brasil - Safra 1976/77 a 2014/15 (Conab, 2015).

Embora o percentual da produção de milho destinado à alimentação humana não seja tão grande em relação à sua produção total, é um cereal com grande importância social por ser um alimento de baixo custo, é a base de várias cadeias agroindustriais e devido à grande parte de seus produtores dependerem de sua produção para sobreviver (Cruz et al, 2011; Galvão et al., 2014). Galvão et al. (2014) destaca ainda a sua importância econômica pelo alto valor nutricional dos seus grãos e pelo seu uso intensivo, na alimentação humana e animal, além de ser matéria prima para a indústria. Em relação 
à participação das regiões brasileiras na quantidade de milho produzida no país, a região Centro Oeste se destaca como a segunda maior produtora $(30,29 \%)$, ficando atrás apenas da região sul (40,77\%) (Conab, 2011).

Analisando-se a evolução da produtividade média da cultura no país (Figura 3.2), observa-se que a produtividade média brasileira apresentou crescimento significativo no período entre os anos agrícolas de 1976/77 a 2014/15 (Conab, 2015). A grande disparidade ainda existente entre o potencial produtivo da cultura e a produtividade média atual pode ser explicada por fatores como o emprego de sementes selecionadas e fertilizantes, tipos de cultivo (simples, consorciado, outro), que isolados ou conjugados entre si, contribuem, parcialmente para as diferenças regionais de produtividade com consequente redução da produtividade média (Amado Neto et al., 2002).

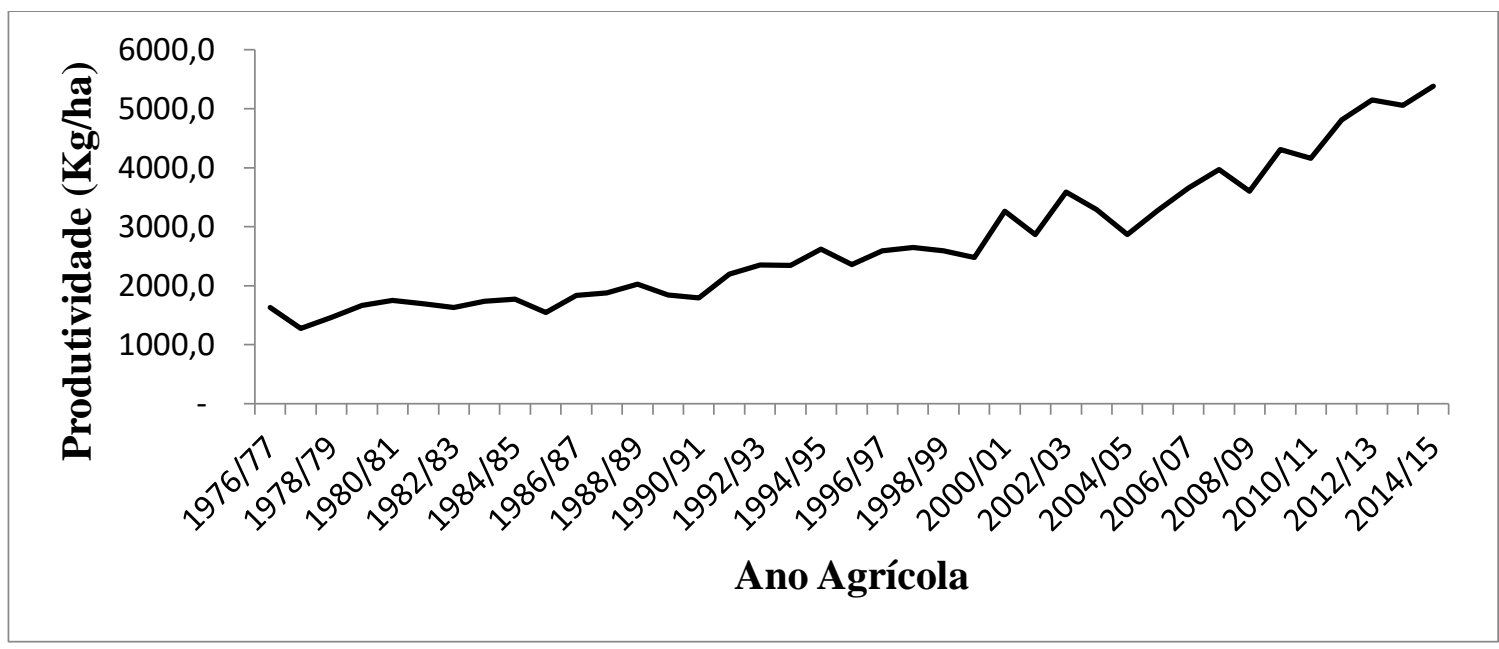

Figura 3.2- Evolução da produtividade da cultura do milho no Brasil - Safra 1976/77 a 2014/15 (Conab, 2015).

Portanto, a busca por tecnologias de fácil e ampla adoção que favoreçam e maximizem o rendimento da cultura do milho, como o uso de plantas de coberturas com potencial de efeito na cultura semeada em sucessão, é fundamental para a redução das disparidades de produtividades regionais existentes. 


\subsection{Influência de plantas de cobertura no milho cultivado em sucessão}

A formação de cobertura do solo antes da instalação da cultura principal pode contribuir na melhoria das características físicas, químicas e biológicas do solo (Barros et al., 2013), além de poder exercer influência sobre a germinação e/ou no desenvolvimento da cultura implantada em sucessão. A influência da cobertura do solo (palhada) poderá ser exercida de diversas formas. Entre os principais efeitos estão o químico, oriundo da decomposição dos resíduos vegetais liberando nutrientes no solo (Noce et al., 2008).

$\mathrm{Na}$ cultura do milho, os resultados referentes às diferentes coberturas do solo antecedendo a semeadura são bem diferenciados. Alguns estudos conduzidos no Cerrado têm demostrado o efeito benéfico de algumas plantas de cobertura antecedendo as culturas comerciais e influenciando positivamente o rendimento das culturas em sucessão (Boer et al., 2008) e na produção de grãos para da cultura do milho (Silva et al., 2008; Pacheco, et al., 2011, Carvalho et al., 2011). Lázaro et al., (2013) obtiverem diferenças significativas das diferentes coberturas do solo na produtividade de grãos do milho. Entretanto, alguns autores não encontraram diferenças significativas para características agronômicas do milho em sucessão a diferentes coberturas do solo. Silva et al., (2014) demonstraram que o sistema de sucessão ou de rotação com plantas de cobertura não promoveu efeitos significativos no desenvolvimento e produção do milho semeado em sucessão. Moda et al. (2014), avaliando a resposta do milho cultivado em sistema de plantio direto com o uso de diferentes plantas de cobertura em pré-safra em JaboticabalSP, não detectaram efeito significativo das plantas de cobertura na produtividade de grãos. Moreira et al. (2014) observaram que as diferentes coberturas do solo não influenciaram a maioria das variáveis agronômicas analisadas, com exceção das concentrações foliares de nitrogênio quando cultivado após girassol e enxofre após nabo forrageiro.

Portanto, a resposta da cultura do milho depende da interação de fatores como a natureza do material (constituição química, relação $\mathrm{C} / \mathrm{N}$, teor de lignina, características do solo e clima do local de cultivo. 


\section{REFERÊNCIAS BIBLIOGRÁFICAS}

ACOSTA, J.A.A; AMADO, T.J.C; SILVA, L.S; SANTI, A; WEBER, M.A. Decomposição da fitomassa de plantas de cobertura e liberação de nitrogênio em função da quantidade de resíduos aportada ao solo sob sistema plantio direto. Ciência Rural, Santa Maria, v. 44, p. 801-809, 2014.

ANDRADE R.S; STONE; L.F; SILVEIRA, P.M. Culturas de cobertura e qualidade física de um Latossolo em plantio direto. Revista Brasileira de Engenharia Agrícola e Ambiental, v.13, p. 411-418, 2009.

ANDERSON, T.H.; DOMSCH, K.H. Application of eco-physiological quotients (qCO2 and qD) on microbial biomasses from soils of different cropping histories. Soil Biol.

Biochem., Oxford, v. 22, n. 2, p. 251-255, 1990.

ARAUJO NETO, S.E; SILVA, A.N; KUSDRA, J.F; KOLLN, F.T; ANDRADE NETO, R.C. Atividade biológica do solo sob cultivo múltiplo de maracujá, abacaxi, milho, mandioca e plantas de cobertura. Revista Ciência Agronômica, v. 45, n. 4, p. 650-658, 2014.

ARIAS, M.E.; GONZÁLES-PÉREZ, J.A.; GONZÁLES-PÉREZ, F.J.;BALL, A.C. Soilhealth a new challenge for microbiologists and chemists. International Microbiology, v. 8, p. 13-21, 2005.

ASSIS, R. L et al. Produção de biomassa, acúmulo de nitrogênio por plantas de cobertura e efeito na produtividade do milho safrinha. Enciclopédia Biosfera, Centro Científico Conhecer, Goiânia, v. 9, n. 16; p. 1769-1775, 2013.

BARETTA, D.; BROWN, G.G.; NOGUEIRA, E.J.B. Potencial da macrofauna e outras variáveis edáficas como indicadores da qualidade do solo em áreas com Araucaria angustifolia. Acta Zoológica Mexicana, v. 2, p. 135-150, 2010.

BARRETO, P.A.B; GAMA-RODRIGUES, E.F; GAMA-RODRIGUES, A.C. Carbono das frações da matéria orgânica em solos sob plantações de eucalipto de diferentes idades. Scientia Florestalis, Piracicaba, v. 42, n. 104, p. 581-590, 2014.

BARROS, D.L; GOMIDE, P.H.L; CARVALHO, G.J. Plantas de cobertura e seu efeito na cultura em sucessão. Biosciense Journal, Uberlândia, v. 29, n. 2, p. 308-318, 2013.

BAYER, C., MIELNICZUK, J., MARTIN-NETO, L., ERNANI, P.R. Stocks and humification degree of organic matter fractions as affected by no-tillage on a subtropical soil. Plant Soil, v. 238, p. 133-140, 2002.

BELL, T., NEWMAN, J. A., SILVERMAN, B. W., TURNER, S. I., LILEY, A. K. The contribution of species richness and composition to bacterial services. Nature, v. 436, p. 1157-1160, 2005.

BOER, C.A; ASSIS, R.L; SILVA, G.P; BRAZ, A.J.B.P; BARROSO, A.L.L; CARGNELUTTI FILHO, A.C; PIRES, F.R. Ciclagem de nutrientes por plantas de 
cobertura na entressafra em um solo de cerrado. Pesquisa Agropecuária Brasileira, v. 42, n. 9, p. 1269-1276, 2007.

BORGES, J.T; BONOMO, R.C; PAULA, C.D; OLIVEIRA, L.C; CESARIO, M.C. Caracteristicas físico-quimicas, nutricionais e formas de consumo da quinoa. (Chenopodium quinoa). Temas agrários. Monteria, v.15, n.1, 2010.

BRASIL. Ministério da Agricultura e Reforma Agrária. Secretaria Nacional de Defesa Agropecuária. Regras de Análises de Sementes. Brasília: Editora do ministério da agricultura e Reforma Agrária, 1992. 1p.

BRESSAN, S.B; NOBREGA, J.C.A; NOBREGA, R.S.A; BARBOSA, R.S; SOUSA, L.B. Plantas de cobertura e qualidade química de latossolo amarelo sob plantio direto no cerrado maranhense. Revista Brasileira de Engenharia Agricola e Ambiental, Campina Grande, v. 17, n. 4, p. 371-378, 2013.

BOER, C. A; ASSIS, R.L; SILVA, G.P; BRAZ, A.J.B.P; BARROSO, A.L.L; CARGNELLUTI FILHO, A; PIRES, F.R. Biomassa, decomposição e cobertura do solo ocasionada por resíduos culturais de três espécies vegetais na região Centro-Oeste do Brasil. Revista Brasileira de Ciência do Solo, Viçosa, v. 32, n. 2, p. 843-851, 2008.

CARVALHO, M.A.C; SORATTO, R.P; ATHAYDE, L.M.F; ARF, O; SÁ, M.E. Produtividade do milho em sucessão a adubos verdes no sistema de plantio direto e convencional. Pesquisa Agropecuária Brasileira, Brasília, v.39, n.1, p.47-53, 2004.

CARVALHO, A.M.; SOUZA, L.L.P.; GUIMARÃES JÚNIOR, R.; ALVES, P.C.A.C.; VIVALDI, L.J. Cover plants with potential use for crop livestock integrated systems in the Cerrado region. Pesquisa Agropecuária Brasileira, v.46, p.1200-1205, 2011.

CARVALHO, W.P; CARVALHO, G.J; ABBADE NETO, D.O; TEIXEIRA, L.G.V. Desempenho agronômico de plantas de cobertura usadas na proteção do solo no período de pousio. Pesquisa Agropecuária Brasileira, Brasilia, v. 48, n. 2, p. 157-166, 2013.

CARVALHO, A.M; COSER, T.R; REIN, T.A; DANTAS, R.A; SILVA, R.R; SOUZA, K.W. Manejo de plantas de cobertura na floração e na maturação fisiológica e seu efeito na produtividade de milho. Pesquisa Agropecuária Brasileira, v.50, n.7, p.551-561, 2015 .

CARDOSO, R.A; BENTO, A.S; MORESKI, H.M; GASPAROTTO, F. Influencia da adubação verde nas propriedades físicas e biológicas do solo e na produtividade da cultura da soja. Semina, Londrina, v. 35, n. 2, p. 51-60, 2014.

CASALI, C.A. Sistemas de culturas sob diferentes manejos em longa duração alteram as formas de fósforo do solo [tese]. Santa Maria: Universidade Federal de Santa Maria; 2012.

CHRISTENSEN, B.T. Organic matter in soil - structure, function and turnover. In: Plant Production. Tjele, 2000. 95p.

CLAESSEN, M.E.C. Manual de métodos de análise de solo. 2. ed. rev. atual. Rio de Janeiro: Embrapa-CNPS, 1997. (Documentos, 1). 
COMPANHIA NACIONAL DE ABASTECIMENTO. Perspectivas para a agropecuária, safra 2014-2015. Pesquisa Agropecuária Brasileira, Brasília, v.2, p. 1-155, 2014.

CONCEIÇÃO, P. C.; BOENI, M.; DIECKOW, J. BAYER, C.; MIELNICZUK, J. Fracionamento densimétrico com politungstato de sódio no estudo da proteção física da matéria orgânica em solos. Revista Brasileira de Ciência do Solo, Viçosa, v. 32, p. 541$549,2008$.

CRUZ, J. C.; PEREIRA FILHO, I. A.; PIMENTEL, M. A. G.; COELHO, A. M.; KARAM, D.; CRUZ, I.; GARCIA, J. C.; MOREIRA, J. A. A.; OLIVEIRA, M. F. de; GONTIJO NETO, M. M.; ALBUQUERQUE, P. E. P. de; VIANA, P. A.; MENDES, S. M.; COSTA, R. V. da; ALVARENGA, R. C.; MATRANGOLO, W. J. R. Produção de milho na agricultura familiar. Sete Lagoas: Embrapa Milho e Sorgo, 2011. 45 p.

DUARTE, I.B; GALLO, A.S; GOMES, M.S; GUIMARÃES, N.F; ROCHA, D.P; SILVA, R.F. Plantas de cobertura e seus efeitos na biomassa microbiana do solo. Acta Iguazu, Cascavel, v. 3, n. 2, p. 150-165, 2014.

ERASMO, E.A.L; DOMINGOS, V.D; SPEHAR, C.R; DIDONET, J; SARMENTO, R.A; CUNHA, A.M. Avaliação de cultivares de amaranto (Amaranthus spp.) em sistema plantio direto no sul do Tocantins. Bioscience Journal, Uberlândia, V.20, n. 1, p. 171176, 2004.

EMBRAPA. Programa de monitoramento da irrigação.Brasília: EMBRAPA, 2012. Disponível em : : <http://hidro.cpac.embrapa.br/index.php>. Acesso em:15 ago 2015.

ESPÍNDOLA, J.A.A. et al. Decomposição e liberação de nutrientes acumulados em leguminosas herbáceas perenes consorciadas com bananeira. Revista Brasileira de Ciência do Solo, v.30, p.321- 328, 2006

FERREIRA, D. F. Sisvar: a computer statistical analysis system. Ciência e Agrotecnologia, Lavras, v. 35, n. 6, p. 1039-1042, 2011.

FERREIRA, C.C; RIBEIRO JUNIOR, W.Q; RAMOS, M.L.G; SPEHAR, C.R; FARIAS, T.R.R. Efeito da densidade de semeadura e doses de nitrogênio sobre a produtividade e biometria de amaranto, no Cerrado do planalto central. Bioscience Journal, Uberlândia, v. 30, supplement 2, p. 534-546, 2014.

FOOD AND AGRICULTURE ORGANIZATION (FAO - FAOSTAT). Alimentos e commodities agrícolas de produção. Ano base: 2012 < http://www.fao.org/economic/ess/ess-trade/en/>. Acesso em 01 julho 2015.

FREIXO, A.A.; CANELLAS, L.P.; MACHADO, P.L.O.A. Propriedades espectrais da matéria orgânica leve-livre e leve intra-agregados de dois Latossolos sob plantio direto e preparo convencional. Revista Brasileira Ciência do Solo, Viçosa, v. 26, p.445-453. 2002.

FIGUEIREDO, C. C.; I; RESCK, D. V. S.; CARNEIRO, M. A. C. Labile and stable fractions of soil organic matter under management systems and native cerrado. Revista Brasileira de Ciência do Solo v.34, p.907- 916, 2010. 
GALVÃO, J.C.C; MIRANDA, G.V; TROGELlO, E; FRITSCHE NETO, R. Sete décadas de evolução do sistema produtivo da cultura do milho. Revista Ceres, Viçosa, v.61, p. 819-828, 2014.

GUERRA, J.G.M.; SANTOS, G. de A.; SILVA, L.S. da; CAMARGO, F.A.O. Macromoléculas e substâncias húmicas. In: SANTOS, G. de A.; SILVA, L.S. da; CANELLAS, L.P.; CAMARGO, F.A.O. Fundamentos da matéria orgânica do solo: ecossistemas tropicais e subtropicais. 2.ed. Porto Alegre: Metrópole, 2008. p.19-25.

GRINHUT, T.; HADAR, Y.; CHEN, Y. Degradation and transformation of humic substances by saprotrophic fungi: processes and mechanisms. Fungal Biology Reviews, v.21, p.179-189, 2007.

GIMPLINGER, D. M.; DOBOS, G.; SCHONLECHNER, R.; KAUL, H. P. Yield and quality of grain amaranth (Amaranthus spp.) in Eastern Austria. Plant Soil Environment, v. 53, p. 105-112, 2007.

GOI, S.R; SOUZA, F.A. Diversidade de microrganismos do solo. Floresta e Ambiente, v. 13, n. 2, p. 46-65, 2006.

GUIMARÃES, D.V; GONZAGA, M.I.S; SILVA, T.O; SILVA, T.L; DIAS, N.S; MATIAS, M.I.S. Soil organic matter pools and carbono fractions in soil under diferente land uses. Soil e Tillage Research, v. 126, p. 177-182, 2013.

HAYNES, R.J. Labile organic matter fractions as central components of the quality of agricultural soils. Advances in Agronomy, v. 85, p. 221-268, 2005.

JENKINSON, D.S.; POWLSON, D.S. The effects of biocidal treatments on metabolism in soil. V. A method for measuring soil biomass. Soil Biol. Biochem., Oxford, v. 8, n. 3, p. 209-213, 1976.

JUNIOR RAMOS, E.U; MACHADO, R.A.F; OLIBONE, D; CASTOLDI, G; RAMOS, B.M. Crescimento de plantas de cobertura sob déficit hídrico. Semina: Ciências agrárias, Londrina, v.34, n.1, p.47-56, 2013.

KELLEHER, B. P.; SIMPSON, M. J.; SIMPSON, A. J. Assessing the fate and transformation of plant residues in the terrestrial environment using HR-MAS NMR spectroscopy. Geochimica et Cosmochimica Acta, v.7, p.4080-4094, 2006.

KENNEDY, A.C; SMITH, K.L. Soil microbial diversity and the sustainability of agricultural soils. Plant and soil, v. 170, p. 75-86, 1995.

KRAGT, M. E.; PANNELL, D. J.; ROBERTSON, M. J.; THAMO, T. Assessing costs of soil carbon sequestration by crop-livestock farmers in Western Australia. Agricultural Systems, Amsterdam, v. 112, n. 10, p. 27-37, 2012.

LEITE, L.F.C; FERREIRA, J.S; VELOSO, M.E.C; MOUSINHO, F.E.P; ROCHA JUNIOR, A.F. Variabilidade espacial das frações da matéria orgânica do solo em área degradada sob recuperação. Revista Brasileira de Engenharia Agrícola e Ambiental, Campina Grande, v. 19, n. 4, p. 394-401, 2015. 
LEITE, L. F. C. et al. Decomposição e liberação de nutrientes de resíduos vegetais depositados sobre Latossolo Amarelo no Cerrado Maranhense. Revista Ciência Agronômica, v. 41, n. 1, p. 29-35, 2010.

LIMA FILHO, O F; AMBROSANO, E.J; ROSSI, F; CARLOS, J.A.D. organizadores. Adubação verde e plantas de cobertura no Brasil: fundamentos e prática. Brasília, DF: Embrapa; 2014. v.1.

LIMA, C.A; RIBEIRO JUNIOR, W.Q; RAMOS, M.L.G; SILVA, N.P; BATISTA, F.P.S; PASINI, L.W; ROCHA, O.C. Yelds and componentes for wheat genotypes under conventional and no-till in four water irrigation levels. In: DE-CAMPOS, A.B; GABRIELS, D; LUJAN, D.L. Impacts of agrosystems on the environment. Belgiun, 2015. p. 9-14.

LIMA, C.A; RIBEIRO JUNIOR, W.Q; RAMOS, M.L.G; SILVA, N.P; BATISTA, F.P.S; PASINI, L.W; ROCHA, O.C. Morphological and physiological evaluations in wheat genotypes under two soil managements and several levels of water. In: DE-CAMPOS, A.B; GABRIELS, D; LUJAN, D.L. Impacts of agrosystems on the environment. Belgiun, 2015. p. 53-58.

MARTIN, T.N; VENTURINI, T; API, I; PAGNOCELLI, A; VIEIRA Jr, P.A. Perfil do manejo da cultura de milho no sudoeste do Paraná. Revista Ceres, v.58, p. 1-8, 2011.

MARTINS, C.M.; GALINDO, I.C.L.; SOUZA, E.R.; POROCA, H.A. Atributos químicos e microbianos do solo de áreas em processo de desertificação no semiárido de Pernambuco. Revista Brasileira de Ciência do Solo, v. 34, p. 1883-1890, 2010.

MEDRADO, R.D; CARVALHO, P.C.F; MORAES, A; RIOS, E.M; LANG, C.R; LOPES, E.C.P. Decomposição de resíduos culturais e liberação de nitrogênio para a cultura do milho. Scientia Agrária, v.12, p.97-107, 2011.

MESCHEDE, D. K.; FERREIRA, A. B; RIBEIRO JUNIOR., C. C. Avaliação de diferentes coberturas na supressão de plantas daninhas no Cerrado. Planta Daninha, Viçosa, v. 25, n. 3, p. 465-471, 2007.

MODA, L.R; SANTOS, C.L.R; FLORES, R.A; BORGES, B, M,M,N; ANDRIOLI, I; PRADO, R.M. Resposta do milho cultivado em sistema de plantio direto à aplicação de doses de nitrogênio e cultivo de plantas de cobertura em pre-safra. Bioscience. Journal., Uberlandia, v.30, p. 178-187, 2014.

MONI C, DERRIEN D, HATTON PJ, ZELLER B, KLEBER M. Density fractions versus size separates: does physical fractionation isolate functional soil compartments Biogeosci. v. 9; p. 8405-47, 2012.

MOREIRA, S.G; LUPP, R.M; LIMA, C.G; MARUCCI, R.C; RESENDE, A.V; BORGES, I.D. Massa seca e macronutrientes acumulados em plantas de milho cultivados sob diferentes espécies de cobertura. Revista Brasileira de Milho e Sorgo, v.13, n.2, p. 218-231, 2014.

NAUTYAL, P. C.; NAGESWARA-RAO, R. C.; JOSHI, Y. C. Moisture deficit induced change in leaf water content, leaf carbon exchange rate and biomass production in 
groundnut cultivars differing in specific leaf area. Field Crops Research, v.74, p. 67-79, 2002.

NOCE, M.A; SOUZA, I.F; KARAM, D; FRANÇA, A.C; MACIEL, G.M. Influência da palhada de gramíneas forrageiras sobre o desenvolvimento da planta de milho e das plantas daninhas. Revista Brasileira de Milho e Sorgo, v.7, n.3, p.265-278, 2008.

NOZAKI, M. H.; VENDRÚSCULO, M. Características químicas e densidade global de um latossolo vermelho eutróferrico cultivado com plantas de cobertura em Toledo-PR. Semina: Ciências Agrárias, Londrina, v. 31, p. 1245-1252, 2010.

PAUL, C. L. El uso de água y nutrientes por la planta de sorgo. In: Agronomia del sorgo. Hydebarad: Índia, 1990. p. 151-208.

PACHECO, L. P; LEANDRO, W.M; MACHADO, P.L.O.A; ASSIS, R.L; COBUCCI, T; MADARI, B.E; PETTER, F.A. Produção de fitomassa e acúmulo e liberação de nutrientes por plantas de cobertura na safrinha. Pesquisa Agropecuária Brasileira, Brasília, v. 46, n. 1, p. 17-25, 2011.

PETTER, F. A; PACHECO, L. P. ; ZUFFO, A. M. ; PIUAILINO, A. C. ; XAVIER, Z. F. ; SANTOS, J. M. ; MIRANDA, J. M. S. . Desempenho de plantas de cobertura submetidas à déficit hídrico. Semina. Ciências Agrárias, v. 34, p. 3307-3320, 2013.

PRIMO, D.C; MENEZES, R.S.C; SILVA, T.O. Substâncias húmicas da matéria orgânica do solo: Uma revisão das técnicas analíticas e estudos no nordeste brasileiro. Scientia Plena, vol. 7, n. 5, 2011.

REATTO,A.; CORREIA,J.R.; SPERA,S.T. Solos do bioma cerrado in: SANO, S.M; ALMEIDA, S.P. (eds.) Cerrado: Ambiente e flora. Brasília, Embrapa cerrados, 1998. p. 47-86.

ROSCOE, R.; MACHADO, P.L.O.A. Fracionamento físico do solo em estudos da matéria orgânica. Dourados: Embrapa Agropecuária Oeste, 2002. 86p.

ROSSI, C. Q.; PEREIRA, M. G.; GIÁCOMO, S. G.; BETTA, M.; POLIDORO, J. C. Frações lábeis da matéria orgânica em sistema de cultivo com palha de braquiária e sorgo. Revista Ciência Agronômica, Fortaleza, v. 43, n. 1, p. 38-46, 2012.

ROSSI, C.Q.; PEREIRA, M.G.; GIACOMO, S.G.; BETTA, M.; POLIDORO, J.C. Frações húmicas da matéria orgânica do solo cultivado com soja sobre palhada de braquiária e sorgo. Bragantia, v.70, p.622-630, 2011.

SANTOS, L.L; LACERDA, J.J.J; ZINN, Y.L. Partição de substâncias húmicas em solos Brasileiros. Revista Brasileira de ciências do solo, v. 37, p. 955-968, 2013.

SANTOS, R. F.; CARLESSO, R. Déficit hídrico e os processos morfológico e fisiológico das plantas. Revista Brasileira de Engenharia Agrícola e Ambiental, Campina Grande, v. 2, n. 3, p. 287-294, 1998.

SILVA, I.R.; MENDONÇA, E.S. Matéria orgânica do solo. In: NOVAIS, R.F.; ALVAREZ V., V.H.; BARROS, N.F.; FONTES, R.L.F.; CANTARUTTI, R.B.; NEVES, J.C.L. (Ed.). Fertilidade do solo. Viçosa: Sociedade Brasileira de Ciência do Solo, 2007. 1017p 
SILVA, A. Z.; JACOBSEN, S. E. ; RAZZAGHI, F.; FLORES, R. A. ; RUIZ, K. B. ; MORALES, A. ; SILVA, H. Estado del arte de la quinua en el mundo en 2013. In: BAZILE, D.; BERTERO, D.; NIETO, C. Estado del arte de la quinua en el mundo en 2013. Santiago do Chile: FAO, 2014. p. $2-22$.

SILVA, A. G; CRUSCIOL, C.A.C; SORATTO, R.P; COSTA, C.H.M; FERRARI NETO, J. Produção de fitomassa e acúmulo de nutrientes por plantas de cobertura e cultivo da mamona em sucessão no sistema plantio direto. Ciência Rural, v. 40, n. 10, p. 20922098, 2010.

SILVA, E. C.; MURAOKA, T.; BUZETTI, S.; ESPINAL, F. S. C.; TRIVELIN, P. C. O. Utilização do nitrogênio da palha de milho e de adubos verdes pela cultura do milho. Revista Brasileira de Ciência do Solo, Viçosa, v. 32, (Número Especial) p. 28532861, 2008.

SILVA, K.F; COSTA, A.C.T; LAZARO, R.L; DOMUKOSKI, J.F; DUARTE, J.B; OLIVEIRA, P.S.R. Desempenho agronômico do milho para produção de silagem, cultivado em sucessão a plantas de cobertura. Scientia agrária paranaensis. Mal. Cdo. Rondon, v.13, n.3, p. 210-218, 2014.

SILVA, J.A.N.; SOUZA, C.M.A.; SILVA, C.J.; BOTTEGA, S.P. Crescimento e produção de espécies forrageiras consorciadas com pinhão-manso. Pesquisa Agropecuária Brasileira, v.47, p.769-775, 2012.

SILVA, A.N; JAYME OLIVEIRA, A; LIMA, C.A; RIBEIRO JUNIOR, W.Q; RAMOS, M.L.G; CELESTINO, S.M.C. Potencial granífero e forrageiro das plantas de cobertura sob regime hídrico variável. Anais do encontro de iniciação científica da Embrapa Cerrados, 2015.

SPEHAR, C. R.; TEIXEIRA, D. L.; CABEZAS, W. A. R. L.; ERASMO, E. A. L. Amaranto BRS Alegria: alternativa para diversificar os sistemas de produção. Pesquisa Agropecuária Brasileira, Brasília, v. 38, n. 5, p. 659-663, 2003.

SPEHAR, C.R; CABEZAS, W.A.R.L. Introdução e seleção de espécies para diversificação do sistema produtivo no cerrado. In CABEZAS, W.A.R.L.; FREITAS, P.L, (Eds.). Plantio direto na integração lavoura pecuária, Uberlândia, MG:UFU. 2001. p 179-188.

SPEHAR, C. R. Production systems in the savannas of Brazil: Key factors to sustainability. In: LAL, R. (Ed.). Soil Quality and Agricultural Sustainability. Ann Arbor Press, Chelsea, Michigan. 1998. p. 301-318. 1998

SPEHAR, C. R.; SANTOS, R. L. B.; SOUZA, P. I. M. Novas plantas de cobertura para o sistema de produção de grãos. In: Seminário Internacional Sobre o Sistema de Plantio Direto, 2., 1997, Passo Fundo. Anais Passo Fundo: EMBRAPA/CNPT, 1997. p. 169-172, 1997.

SPEHAR, C. R. Quinoa: alternativa para a diversificação agrícola e alimentar. Planaltina: Embrapa Cerrados, 2007. 103p.

SWIFT, R.S. Method for extraction of IHSS soil fulvic and humic acids. In: SPARKS, D.L.; PAGE, A.L.; HELMKE, P.A.; LOEPPERT, R.H.; SOLTANPOUR, P.N.; TABATABAI, M.A.; JOHNSTON, C.T. \& SUMMER, M.E., eds. Methods of soil 
analysis. Part 3. Chemical methods. Madison, Soil Science Society of America Books, 1996. p.1018-1020.

TEIXEIRA, C. M. et al. Liberação de macronutrien-tes das palhadas de milheto, solteiro e consorciado com feijão-de-porco sob cultivo de feijão. Revista Brasileira de Ciência do Solo, Viçosa, v. 34, n. 2, p. 497-505, 2010.

TEIXEIRA, D. L.; SPEHAR, C. R.; SOUZA, L. A. C. Caracterização agronômica de amaranto para cultivo na entressafra no Cerrado. Pesquisa Agropecuária Brasileira, Brasília, v. 38, n. 1, p. 45-51, jan. 2003.

TORRES, J.L.R; CUNHA, M.A; PEREIRA, M.G; VIEIRA, D.M.S. Cultivo de feijão e milho em sucessão a plantas de cobertura. Revista Caatinga, v. 27, n. 4, p. 117-125, 2014.

TORRES, J. L. R. et al. Produtividade de feijão so-bre lâminas de irrigação e Coberturas de solo. Bioscience Journal, Uberlândia, v. 29, n. 4, p. 833-841, 2013.

VALENCIA, Y.K.D. Características de grãos e amido de diferentes cultivares de quinoa. [dissertação]. Piracicaba: Escola Superior de Agricultura Luiz de Queiroz; 2016.

VANCE, E.D. et al. An extraction method for measuring soil microbial biomass C. Soil Biol. Biochem., Oxford, v. 19, n. 6, p. 703-707, 1987.

VEZZANI, F. M.; MIELNICZUK, J. Uma visão sobre qualidade do solo. Revista Brasileira de Ciência do Solo, v. 33, n. 4, p. 743-755, 2009.

VINHAL-FREITAS, I.C.; WANGEN, D.R.B.; FERREIRA, A.S.; CORRÊA, G.F.; WENDLING, B. Microbial and enzymatic activity in soil after organic composting. Revista Brasileira Ciência do Solo, v. 34, n.3, p. 757-764, 2010.

ZILLI, J.E; RUMJANEK, N.G; XAVIER, G.R; COUTINHO, H.L.C; NEVES, M.C.P; Diversidade microbiana como indicador da qualidade do solo. Cadernos de Ciencia e Tecnologia, Brasília, v. 20, n. 3, p. 391-411, 2003.

ZOTARELLI, L.; ZATORRE, N. P.; BODDEY, R. M.; JANTALIA, C. P.; URQUIAGA, S.; FRANCHINI, J. C.; ALVES, B. R. Influence of no-tillage and frequency of a green manure legume in crop rotations for balancing $\mathrm{N}$ outputs and preserving soil organic $\mathrm{C}$ stocks. Field Crops Research, In Press, Corrected Proof, 2012.

WINCK, B.R; VEZZANI, F.M; DIECKOW, J; FAVARETTO, N; MOLIN, R. Carbono e nitrogênio das frações granulométricas da matéria orgânica particulada do solo, em sistemas de culturas sob plantio direto. Revista Brasileira de Ciências do solo, v. 38, p. 980-989, 2014.

WHITMAN, W.B; COLEMAN, D.C; WIEBE, W.J. Prokaryotes: the unseen majority. Proceedings of the National Academy of Sciences of the U.S.A. v. 95, p. 6578-6583, 1998. 


\section{CAPITULO I}

DESEMPENHO AGRONÔMICO DE PLANTAS DUPLO PROPÓSITO DE COBERTURA E GRÃOS CULTIVADAS SOB REGIMES HÍDRICOS VARIÁVEIS 


\section{DESEMPENHO AGRONÔMICO DE PLANTAS DUPLO PROPÓSITO DE COBERTURA E GRÃOS CULTIVADAS SOB REGIMES HÍDRICOS VARIÁVEIS NO CERRADO BRASILEIRO}

\subsection{RESUMO}

Esse trabalho teve por objetivo avaliar o desempenho de plantas duplo propósito com potencial para cobertura e grãos, cultivadas sob regimes hídricos variáveis na região Centro Oeste do Brasil. O experimento foi desenvolvido em condições de campo, de maio a outubro de 2015, na área experimental da Embrapa Cerrados, localizada no município de Planaltina - DF. Os tratamentos foram dispostos em blocos casualizados, com parcelas subdivididas e quatro repetições. As parcelas foram compostas por quatro regimes hídricos $(167 \mathrm{~mm} ; 268 \mathrm{~mm} ; 381 \mathrm{~mm} ; 432 \mathrm{~mm})$ e as subparcelas foram compostas pelas seguintes plantas de cobertura: amaranto "BRS Alegria" (Amaranthus cruentus), quinoa, "Genótipo derivado do BRS Piabiru" (Chenopodium quinoa, Wild) e milheto (Pennisetum glaucum). Foram avaliadas a biomassa da parte aérea fresca (BF) e seca (BS), teor e acúmulo de macro e micronutrientes na parte aérea e produtividade de grãos. Em condições de adequado suprimento de água (381 e $432 \mathrm{~mm}$ ), o amaranto apresentou a maior produção de biomassa fresca. Quanto à produção de biomassa seca as menores médias foram observadas na quinoa. De maneira geral, o amaranto foi a espécie com maior teor e acúmulo de macro e micronutrientes e o milheto foi a espécie que apresentou os menores acúmulos. O elevado potencial de produção de grãos, associado a outras características como produção de biomassa e acúmulo de nutrientes, pode determinar a inclusão do amaranto no sistema de plantio direto. A quinoa, devido a sua maior capacidade de acúmulo de nutrientes que o milheto e seu elevado potencial de produção de grãos também pode ser uma alternativa ao milheto.

Palavras-chave: Amaranthus cruentus; Chenopodium quinoa; Pennisetum glaucum; cobertura do solo; disponibilidade hídrica;

\subsection{ABSTRACT}

The objective of this work was to evaluate the performance of dual purpose plants with potential for cover and grains cultivated under variable water regimes in the Centro Oeste region of Brazil. The experiment was carried out in field conditions, from May to October, 2015, in the experimental area of Embrapa Cerrados, located in the city of Planaltina DF. The treatments were arranged in randomized blocks, with subdivided plots and four replications. The plots were composed of four water regimes $(167 \mathrm{~mm}, 268 \mathrm{~mm}, 381 \mathrm{~mm}$, $432 \mathrm{~mm}$ ) and the subplots were composed of the following cover plants: BRS Alegria (Amaranthus cruentus), quinoa, "Genotype derived from BRS Piabiru "(Chenopodium quinoa, Wild) and millet (Pennisetum glaucum). Biomass of fresh aerial (BF) and dry (BS), macro and micronutrient contents and accumulation in shoot and grain yield were evaluated. Under conditions of adequate water supply, amaranth presented the highest production of fresh biomass. Taking into account the variable production of fresh 
biomass, the cultivation of amaranth, proved to be a better option than the cultivation of the other species studied, because it presented a higher fresh biomass. As for dry biomass production, the lowest averages were observed in quinoa. In general, amaranth was the species with the highest content and accumulation of macro and micronutrients, and millet was the species with the lowest accumulations. The high potential of grain production, associated with other characteristics such as biomass production and nutrient accumulation, can determine the inclusion of amaranth in the no-tillage system. Quinoa, due to its greater nutrient accumulation capacity than millet and its high potential for grain production can also be an alternative to millet.

Keywords: Amaranthus cruentus; Chenopodium quinoa; Pennisetum glaucum; Soil cover; Water availability;

\subsection{INTRODUÇÃO}

O sistema plantio direto (SPD) pode ser considerado um dos grandes avanços no sistema de produção agrícola brasileiro (Ziech et al., 2015). Esse sistema é fundamentado em três requisitos mínimos: não revolvimento do solo, rotação de culturas e manutenção dos restos vegetais na superfície do solo (Lima et al., 2015). Entretanto, para que este sistema seja eficiente é fundamental um adequado manejo do solo, com uso de práticas conservacionistas mecânicas, edáficas e vegetativas, entre as quais se destaca o uso de plantas de cobertura (Carvalho et al., 2015).

Entre as espécies utilizadas como plantas de cobertura na região do Cerrado, o milheto [Pennisetum glaucum (L.) R. Brown] é uma espécie que se destaca e caracterizase por rápido crescimento e estabelecimento no campo, mesmo em condições de estresse hídrico (Silva et al., 2010; Padovan et al., 2011; Soratto et al., 2012). Além disso, esta espécie possui alto acúmulo de matéria seca e macro e micronutrientes (Nozaki e Vendrusculo 2010).

A baixa diversidade de espécies vegetais possíveis de serem utilizadas como plantas de cobertura ou em rotação de culturas ocasionam, ao longo do tempo, problemas típicos de monocultivo (Erasmo et al., 2004). O uso de milheto e sorgo em antecipação ou sucessão a culturas comerciais tem limitado o número de espécies para apenas uma família botânica, as gramíneas (Spehar e Lara Cabezas, 2001). Portanto, a introdução de novas espécies de plantas de cobertura no cenário produtivo torna-se interessante do 
ponto de vista econômico e conservacionista devido à maior diversificação do sistema de produção e aporte de material diferenciado para cobertura do solo (Pittelkow et al., 2012).

Uma alternativa para a utilização de plantas de cobertura são os pseudocereais, que tem apresentado boa adaptação à região do Cerrados. Dentre os pseudocereais, o amaranto (Amaranthus cruentus) possui características bastante promissoras (Ferreira et al., 2014). Essa planta possui raiz pivotante e vigorosa, com abundante ramificação, cria condições favoráveis à absorção de água e nutrientes e por isso tem facilidade de se adaptar a regiões áridas ou em locais com período seco prolongado (Spehar, 2007)

A quinoa (Chenopodium quinoa Willd) é outra espécie caracterizada como pseudocereal que vem apresentando boa adaptação à região do Cerrado, pela quantidade de biomassa que produz, além de ser uma alternativa para a proteção do solo em plantio direto no Cerrado (Spehar, 1998; Rocha, 2008).

O desempenho das plantas de cobertura está relacionado, entre outros fatores, à qualidade e quantidade dos seus resíduos depositados na superfície do solo (Pires et al., 2008; Bressan et al., 2013). Em relação à qualidade, características como teor de hemicelulose, celulose e lignina (Espindola et al., 2006; Carvalho et al., 2008; Carvalho et al., 2009; Acosta et al., 2014; Carvalho et al., 2015) são fatores importantes na formação e manutenção de palhada no solo. Quanto à quantidade, destacam-se a produção de biomassa fresca e seca das espécies utilizadas para cobertura do solo.

Outro fator importante para a avaliação do desempenho de plantas de cobertura diz respeito à sua capacidade de absorção e acúmulo de nutrientes, que poderá influenciar de forma positiva o rendimento de culturas subsequentes. Alguns estudos na região do Cerrado têm demonstrado o efeito benéfico das plantas de cobertura antecedendo as culturas comerciais (Torres et al., 2013; Torres et al., 2014; Cardoso et al., 2014). Tal fato pode ser atribuído à contínua liberação de nutrientes na superfície do solo após a decomposição dos seus resíduos vegetais (Pacheco et al., 2011; Carvalho et al., 2015)

A produção de biomassa, absorção e acúmulo de nutrientes pelas plantas, entre outras características, está condicionada a processos fisiológicos inerentes aos cultivos utilizados (Fageria et al., 1995) e à sua adaptabilidade à disponibilidade de água (Crusciol et al., 2003). Alguns trabalhos evidenciam o efeito da disponibilidade hídrica nos atributos morfológicos e fisiológicos das plantas (Crusciol et al., 2003; Scalco et al., 
(2013). Entretanto, ainda são escassos os trabalhos que avaliam o desempenho de plantas de cobertura sob diferentes regimes hídricos.

Portanto, visando auxiliar a escolha das espécies que melhor se adaptam a diferentes condições hídricas, esse trabalho teve por objetivo avaliar o desempenho de potenciais plantas de cobertura comparadas com uma espécie tradicional para esta finalidade, cultivadas sob regimes hídricos variáveis na região Centro Oeste do Brasil.

\subsection{MATERIAL E MÉTODOS}

O experimento foi conduzido no período entre maio e outubro de 2015, no campo experimental da Embrapa Cerrados - Planaltina DF, cujas coordenadas geográficas são: 15³5’30" (latitude sul) 4742’30" (longitude oeste), e altitude média de $1.014 \mathrm{~m}$. A região encontra-se no bioma Cerrado e o clima, segundo a classificação de Koppen, é classificado como Aw (Koppen), com duas estações bem definidas (seca e chuvosa). No inverno ocorre déficit hídrico e baixas temperaturas. O verão é quente e úmido, com a ocorrência de períodos de estiagem durante a estação chuvosa (veranicos).

A precipitação e a temperatura média anual são de $1.460 \mathrm{~mm}$ e $21,3^{\circ} \mathrm{C}$, respetivamente. Os dados de temperaturas médias mínimas e máximas e precipitação pluvial durante o estudo foram coletados na estação meteorológica da Embrapa Cerrados, localizada adjacente à área experimental (Figura 5.1).

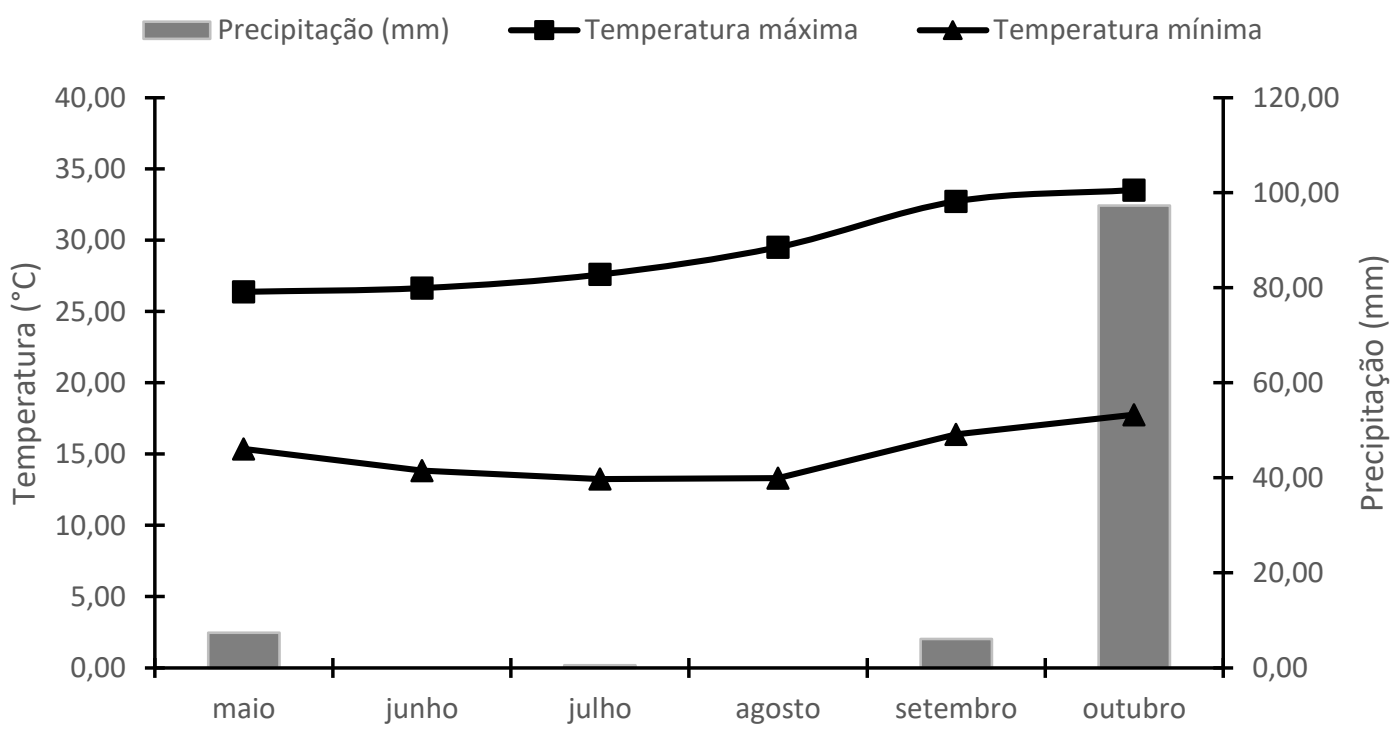


Figura 5.1: Precipitação pluviométrica e temperaturas máximas e mínimas ocorridas na área experimental nos meses de maio a outubro de 2015. *Dados obtidos de estação automática localizada próxima à área experimental.

O solo é classificado como Latossolo vermelho A moderado, textura argilosa, fase Cerrado, relevo plano (Santos et al., 2013). A análise química do solo antes da instalação do experimento está apresentada na tabela 5.1.

Tabela 5.1 - Análise química do solo da área experimental, nas profundidades de 0-10, 10-20, 20-30 cm, realizada em abril/2013.

\begin{tabular}{|c|c|c|c|c|c|c|c|c|}
\hline \multirow{2}{*}{$\begin{array}{l}\text { Profundidade } \\
(\mathrm{cm})\end{array}$} & $\mathrm{pH}$ & $\mathrm{Ca}$ & $\mathrm{Mg}$ & $\mathrm{K}$ & $\mathrm{H}+\mathrm{Al}$ & $\mathrm{P}$ & $\mathrm{S}$ & M.O \\
\hline & $\begin{array}{l}\text { em } \\
\text { água }\end{array}$ & $\mathrm{cmoc} / \mathrm{dm}^{3}$ & $\mathrm{cmoc} / \mathrm{dm}^{3}$ & $\mathrm{mg} / \mathrm{dm}^{3}$ & $\mathrm{cmoc} / \mathrm{dm}^{3}$ & $\mathrm{mg} / \mathrm{dm}^{3}$ & $\mathrm{mg} / \mathrm{kg}$ & $\%$ \\
\hline $0-10$ & 5,75 & 3,33 & 1,39 & 205,88 & 4,61 & 46,87 & 19,17 & 2,61 \\
\hline $10-20$ & 5,80 & 3,35 & 1,43 & 209,25 & 4,44 & 50,26 & 20,25 & 2,58 \\
\hline $20-30$ & 5,82 & 3,25 & 1,39 & 236,00 & 4,44 & 47,46 & 20,49 & - \\
\hline
\end{tabular}

O histórico dos últimos quatro anos de cultivo da área experimental está apresentado na Tabela 5.2.

Tabela 5.2: Descrição do histórico de cultivo da área de estudo sob sistema de plantio direto no período compreendido entre 2011 - 2015.

\begin{tabular}{clc}
\hline & \multicolumn{2}{c}{ Período } \\
\cline { 2 - 3 } Safra & \multicolumn{1}{c}{ Inverno } & Verão \\
\hline $2011 / 2012$ & Soja sob regime hídrico variável & Pousio \\
$2012 / 2013$ & Trigo sob regime hídrico variável & Crotalária \\
$2013 / 2014$ & Amaranto, milheto e quinoa sob regime hídrico variável & Crotalária \\
$2014 / 2015$ & Amaranto, milheto e quinoa sob regime hídrico variável & Milho \\
\hline
\end{tabular}

Os tratamentos foram dispostos em blocos casualizados, com parcelas subdivididas e quatro repetições. As parcelas foram compostas por quatro regimes hídricos (167 mm; $268 \mathrm{~mm} ; 381 \mathrm{~mm} ; 432 \mathrm{~mm}$ ) e as subparcelas foram compostas pelas seguintes plantas de cobertura: amaranto "BRS Alegria" (Amaranthus cruentus), quinoa, "material derivado do BRS Piabiru com ciclo mais curto" (Chenopodium quinoa, Wild) e milheto (Pennisetum glaucum). As dimensões das parcelas foram de 24 x 3,2 m e as subparcelas foram $8 \times 3,2 \mathrm{~m}$. 
A semeadura das três espécies foi realizada manualmente, sem revolvimento sob sistema de plantio direto. Foi utilizado espaçamento de $0,4 \mathrm{~m}$ entre linhas e densidade de plantio de 200 sementes/m para amaranto, 150 sementes $/ \mathrm{m}$ para quinoa e 58 sementes $/ \mathrm{m}$ para milheto. A elevada taxa de semeadura utilizada teve o objetivo de evitar desuniformidade do stand final devido a falhas na germinação ocasionadas pelo pequeno tamanho das sementes. O excedente foi retirado por desbaste aos 20 dias após a emergência (DAE), obtendo-se um stand de 10 plantas $/ \mathrm{m}$ para amaranto e 20 plantas $/ \mathrm{m}$ para quinoa e milheto.

A adubação de base foi feita nos sulcos na dose de $400 \mathrm{~kg} / \mathrm{ha}$ da fórmula 04-3016. Foi realizada adubação nitrogenada de cobertura a lanço, aos 30 dias após a emergência das plântulas na dose de $100 \mathrm{~kg} / \mathrm{ha}$ de $\mathrm{N}$ na forma de ureia. Para evitar a competição das plantas invasoras foram realizadas capinas manuais. $\mathrm{O}$ controle de pragas foi realizado por meio da aplicação de defensivos químicos.

Os diferentes regimes hídricos foram obtidos utilizando barra irrigadora de aspersão com $40 \mathrm{~m}$ de largura, ligada ao carretel com velocidade regulável. Em cada lateral da barra irrigadora foram instalados oito aspersores uniformemente espaçados. Durante os primeiros 35 dias após a emergência (DAE) a irrigação foi uniforme. Durante esse período foram realizadas dez irrigações totalizando uma lâmina de $135 \mathrm{~mm}$. Após este período foi adaptada a metodologia do line source (HANKS et al., 1976), utilizandose bocais de orifícios decrescentes da área central até o $6^{\circ}$ aspersor e excluindo os dois aspersores da extremidade, constituindo quatro regimes hídricos. Para cada lateral da barra irrigadora foram delimitadas 4 parcelas com 3,2 metros de largura e 1 metro de distância entre parcelas, representando os regimes hídricos. Nessa fase foram realizadas 13 irrigações e a lâmina acumulada das irrigações uniformes e variáveis foi de 167, 268, 381, $432 \mathrm{~mm}$ para os quatro regimes em estudo. Para determinar o valor da lâmina aplicada foram instaladas, a cada turno de rega, duas fileiras de coletores paralelas à linha de irrigação para medição do volume de água em cada evento de irrigação.

As irrigações foram realizadas conforme descrito no programa de monitoramento de irrigação no Cerrado (EMBRAPA, 2011), utilizando-se como referência a cultura do trigo, os indicadores agrometeorológicos da região, o tipo de solo e a data de germinação plena. $\mathrm{O}$ fornecimento de água foi interrompido para todos os tratamentos no ponto de maturidade fisiológica das plantas de cobertura (grãos em massa). 
A avaliação do desempenho das plantas de cobertura foi realizada por meio das análises das variáveis biomassa da parte aérea fresca (BF) e seca (BS), teor e acúmulo de macro e micronutrientes na parte aérea e produtividade de grãos.

A avaliação da produção de biomassa fresca foi realizada colhendo-se uma amostra por parcela na fase de pleno florescimento da cultura, com área de $3 \mathrm{~m}^{2}$ cada, coletandose quatro linhas centrais, com 2,5 m de comprimento. O material coletado foi pesado e convertido para t/ha. Para a determinação da biomassa seca por planta, foram retiradas amostras contendo três plantas do material coletado para determinação da biomassa fresca, colocados em sacos de papel e levados à estufa a $65^{\circ} \mathrm{C}$, por 72 horas, até atingir peso constante.

Os teores de fósforo $(\mathrm{P})$, potássio $(\mathrm{K})$, magnésio $(\mathrm{Mg})$, cálcio $(\mathrm{Ca})$, enxofre $(\mathrm{S})$, cobre $(\mathrm{Cu})$, manganês $(\mathrm{Mn})$, zinco $(\mathrm{Zn})$, boro $(\mathrm{B})$ e ferro $(\mathrm{Fe})$ foram determinados na matéria seca da parte aérea da planta (folhas e caules), de acordo com Malavolta et al. (1997). O acúmulo de macro e micronutrientes nas plantas foi calculado pelo produto entre o teor do elemento no tecido vegetal e a quantidade de biomassa seca produzida.

A produtividade de grãos das três espécies foi mensurada por meio da colheita mecânica de todas as plantas de uma área de 7,2 $\mathrm{m}^{2} /$ parcela. Após a colheita, a massa total de grãos foi pesada, retirando-se uma subamostra de $300 \mathrm{~g}$. Essa subamostra foi levada para estufa de circulação forçada a $65^{\circ} \mathrm{C}$, até peso constante, para determinação do teor de umidade dos grãos. Posteriormente, corrigiu-se a produtividade para umidade padrão de $13 \%$ e os resultados foram expressos em $\mathrm{Kg} / \mathrm{ha}$.

Todas estas medições foram feitas no inverno porque não ocorrem precipitações e pode-se obter níveis de água diferenciais através da irrigação em níveis. Como via de regra utiliza-se plantas de cobertura no período chuvoso, em que a temperatura é maior do que a época em que foi plantado este experimento, uma validação no período chuvoso seria necessário.

A análise estatística foi feita pela análise de variância (ANOVA). O modelo estatístico foi ajustado utilizando-se o procmixed do SAS, por meio do método de máxima verossimilhança restrita (reml). As fontes de variação foram os regimes hídricos ( $\mathrm{Rh})$ (parcelas), as plantas de cobertura (Pc) (subparcelas) e suas interações. Para a comparação 
das médias foi utilizado o teste de Tukey, ao nível de probabilidade de 5\%. Todas as análises foram realizadas pelo software estatístico SAS versão 9.

\subsection{RESULTADOS E DISCUSSÃO}

\section{Produção de biomassa}

São apresentados, na Tabela 5.3, os valores de F da análise de variância para biomassa fresca (BF) e biomassa seca (BS). Houve efeitos altamente significativos $(\mathrm{p}<0,01)$ dos fatores regime hídrico e planta de cobertura para biomassa fresca e seca. Houve interação significativa entre regime e plantas de cobertura $(\mathrm{p}<0,01)$ apenas para BF.

Tabela 5.3: Análise de variância (valores de F) para as variáveis biomassa fresca (BF), biomassa seca (BS), em função dos regimes hídricos e das plantas de cobertura.

\begin{tabular}{|c|c|c|}
\hline \multirow{2}{*}{ Causa variação } & Biomassa fresca & Biomassa seca \\
\hline & \multicolumn{2}{|c|}{ F calculado } \\
\hline Planta de cobertura & $14,69 * *$ & $11,64 * *$ \\
\hline Regime hídrico & $48,46^{* *}$ & $13,65^{* *}$ \\
\hline Regime x Planta & $6,25 * *$ & $2,09^{\mathrm{ns}}$ \\
\hline
\end{tabular}

ns - Não significativo; ** significativo a $1 \%$ de probabilidade pelo teste $\mathrm{F}(\mathrm{p}<0,01)$.

O desdobramento da interação dos fatores mostra que a maior produção de BF foi obtido para a cultura do amaranto nos dois regimes hídricos superiores, com valores de 73,91 t.ha ${ }^{-1}$ e 70,46 , respectivamente, enquanto que a menor produção (17,54 t.ha $\left.{ }^{-1}\right)$ ocorreu no regime hídrico inferior na cultura da quinoa (Tabela 5.4).

Comparando os diferentes regimes hídricos para cada espécie, como as diferenças em milheto só apareceram no regime hídrico mais estressado (167mm), enquanto que nos pseudocereais já ocorrem a partir de $268 \mathrm{~mm}$ (Tabela 5.4.), isso é um indicativo de maior tolerância à seca no milheto. A comparação entre espécies dentro de cada regime hídrico mostra nos dois regimes mais estressados, apenas a quinoa como material mais sensível à seca que os demais. Ainda na tabela 5.4. Verifica-se que nos níveis ótimo e com stress médio, o amaranto se destaca dos demais. Entretanto, dados de matéria fresca podem apenas estar computando mais água, o que pode ter acontecido considerando que para matéria seca a interação não foi significativa. 
Na cultura da quinoa e do amaranto, os regimes de 381 e $432 \mathrm{~mm}$ apresentaram as maiores produções quando comparadas aos regimes inferiores, evidenciando o elevado potencial de resposta das duas espécies quando submetidas a condições de maior disponibilidade hídrica, mas também, drásticas reduções na produção de BF quando em condições de menor regime hídrico. Entretanto, mesmo com a drástica redução, nos menores regimes hídricos, a produção de biomassa fresca no amaranto assemelhou-se à cultura do milheto e foi superior a cultura da quinoa.

Comparando-se o maior regime hídrico com o menor, houve uma redução de $59,36 \%, 50,62 \%$ e $21,92 \%$ para a quinoa, amaranto e milheto, respectivamente. $\mathrm{O}$ milheto, apesar de produzir aproximadamente a metade da biomassa fresca nos dos regimes hídricos superiores, sob estresse hídrico não foi afetado até a lâmina $268 \mathrm{~mm}$. Alguns autores consideram o milheto como uma espécie que, devido ao seu sistema radicular vigoroso, possui tolerância à seca, é eficiente no uso de água e que apresenta boa recuperação após um período de estresse hídrico (Silva et al., 2010; Padovan et al., 2011; Marcante et al., 2011; Soratto et al., 2012;), apesar de alguns estudos sobre crescimento de plantas de cobertura sob déficit hídrico apontam que essa espécie é severamente afetada pela redução na disponibilidade hídrica (Lemos et al., 2003; BonfimSilva et al., 2011; Ramos Junior et al., 2013).

Tabela 5.4: Desdobramento da interação significativa entre plantas de cobertura e regime hídrico para produção de biomassa fresca (BF).

\begin{tabular}{cccc}
\hline \multirow{2}{*}{$\begin{array}{c}\text { Regime } \\
\text { hídrico }(\mathrm{mm})\end{array}$} & \multicolumn{3}{c}{ Planta de cobertura } \\
\cline { 2 - 4 } & Amaranto & Milheto & Quinoa \\
\hline $\mathbf{1 6 7}$ & $34,79 \mathrm{Ac}$ & Biomassa fresca $\left(\mathrm{t} \mathrm{ha}^{-1}\right)$ \\
$\mathbf{2 6 8}$ & $54,12 \mathrm{Ab}$ & $35,33 \mathrm{Ab}$ & $17,54 \mathrm{Bc}$ \\
$\mathbf{3 8 1}$ & $73,91 \mathrm{Aa}$ & $45,91 \mathrm{Aa}$ & $28,83 \mathrm{Bb}$ \\
$\mathbf{4 3 2}$ & $70,46 \mathrm{Aa}$ & $45,87 \mathrm{Ba}$ & $40,00 \mathrm{Ba}$ \\
\hline
\end{tabular}

Médias seguidas pelas mesmas letras, maiúsculas nas linhas e minúsculas nas colunas, não diferem entre si pelo teste de Tukey ao nível de $5 \%$.

Houve diferença significativa das plantas de cobertura e regimes hídricos para biomassa seca (Figura 5.2). O amaranto e o milheto apresentaram a maior produção de matéria seca, com 13,26 e 13,33 t ha ${ }^{-1}$, respectivamente. A produção de BS dessas duas culturas está, acima da quantidade requerida para que se tenha cobertura plena e eficiente proteção do solo, estimada em 11,00 a 12,00 t ha-1 (Alvarenga et al., 2001; Bayer, 1996), 
devido à alta taxa de decomposição dos resíduos vegetais nas regiões tropicais. Boer et al., (2008) em trabalho realizado com o milheto ADR500 e Carvalho et al., (2015) com o milheto BR05, ambos na região Centro-Oeste do Brasil, e Borges et al. (2015) na região Noroeste de São Paulo, obtiveram produtividades de 10,81, 4,62 e 7,40 t ha ${ }^{-1}$ de biomassa seca para o milheto, respectivamente, apresentando valores inferiores aos obtidos no presente trabalho. Já Costa et al., (2015), estudando o efeito de espaçamento e diferentes épocas de plantio no desempenho de espécies forrageiras na região sudeste, observaram produtividade de até $17,05 \mathrm{t} \mathrm{ha}^{-1}$ para o milheto.

Com relação ao amaranto, os valores de biomassa seca obtidos no presente trabalho foram bastante superiores a outros relatados na literatura (Erasmo et al., 2004; Boer et al., 2007; Costa et al., 2008; Ferreira et al., 2014). Essa diferença de produtividade está relacionada com as condições climáticas, a disponibilidade hídrica proporcionada pelos diferentes regimes hídricos, as cultivares utilizadas e, principalmente, a adubação de base realizada para a produção de grãos, prática incomum no cultivo de plantas de cobertura.

A quinoa foi a espécie com menor produção de BS $\left(9,75 \mathrm{t} \mathrm{ha}^{-1}\right)$. Spehar e Trecenti (2011) em estudo sobre o desempenho agronômico de plantas de cobertura na região do cerrado, encontraram produção de biomassa total igual a $6,2 \mathrm{tha}^{-1}$ para a quinoa BRS Piabiru.

Quanto ao fator regime hídrico, a menor produção de biomassa seca ocorreu na lâmina inferior que é uma condição de stress severo e pouco comum em área de produtores e não houve diferença estatística nos demais regimes, sugerindo que essas plantas de cobertura (principalmente amaranto e milheto) são tolerantes à seca e são promissoras para utilização no cerrado brasileiro. 

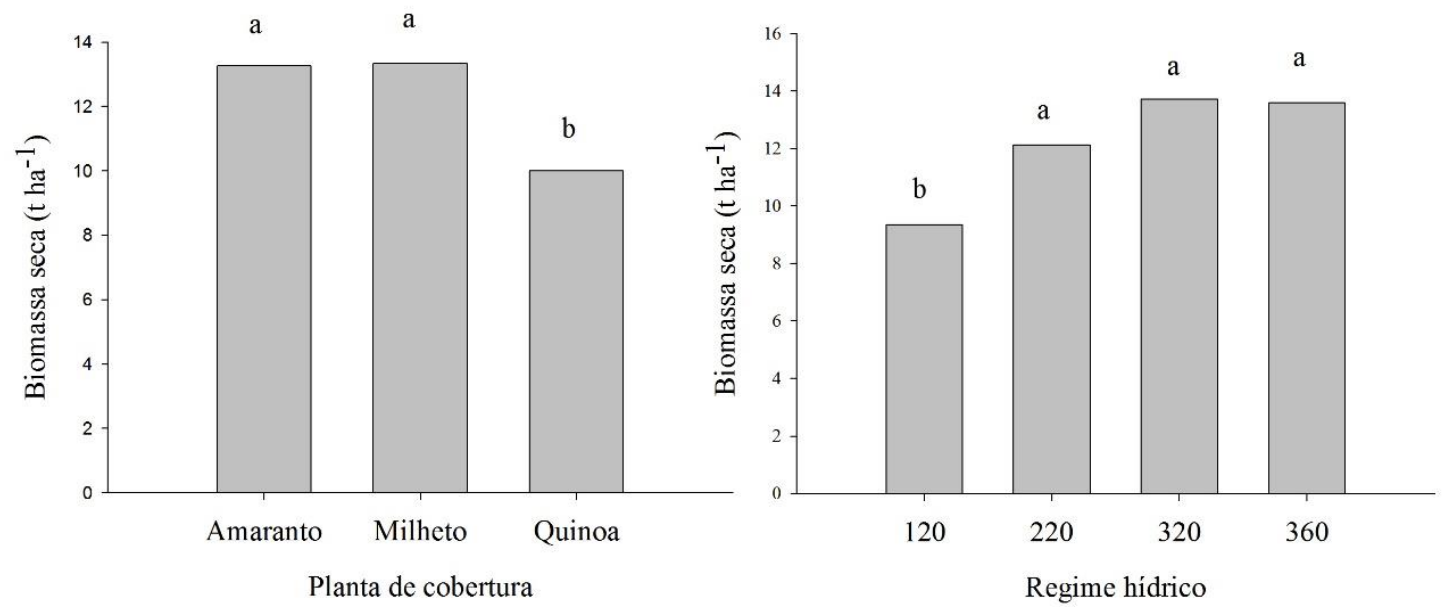

Figura 5.2: Médias de biomassa seca $\left(\mathrm{t} \mathrm{ha}^{-1}\right)$ para os fatores planta de cobertura e regime hídrico. Médias seguidas pela mesma letra não diferem entre si, ao nível de $5 \%$ de probabilidade pelo teste de Tukey.

\section{Teor de macro e micronutrientes na parte aérea}

Na Tabela 5.5 encontram-se os valores de F para os teores e acúmulo de macro e micronutrientes na parte aérea. Com relação aos teores, a interação entre os fatores estudados foi significativa $(\mathrm{p}<0,05)$ para Zinco $(\mathrm{Zn})$ e Boro (B). Nos teores de Fósforo $(\mathrm{P})$, Cálcio $(\mathrm{Ca})$, Magnésio $(\mathrm{Mg})$ e Enxofre $(\mathrm{S})$ houve diferença significativa para os fatores planta de cobertura e regime. Para os teores de Potássio (K) e Manganês (Mn) houve diferença apenas entre as plantas de cobertura e para Ferro $(\mathrm{Fe})$ houve significância apenas para o fator Regime hídrico. $\mathrm{O}$ micronutriente Cobre $(\mathrm{Cu})$ não foi influenciado por nenhum fator.

Tabela 5.5: Análise de variância (valores de F) para os teores e acúmulo de macro e micronutrientes na parte aérea em função das plantas de cobertura e do regime hídrico.

\begin{tabular}{cccccc}
\hline Causa de & \multicolumn{5}{c}{ F calculado } \\
\cline { 2 - 6 } Variação & $\mathbf{5}$ & Teor \\
\hline \multicolumn{5}{c}{ Macronutrientes } \\
\hline Planta de & $\mathbf{P}$ & $\mathbf{C a}$ & $\mathbf{M g}$ & $\mathbf{S}$ \\
cobertura & $23,62^{* *}$ & $43,12^{* *}$ & $67,97 * *$ & $188,69^{* *}$ & $54,02^{* *}$ \\
Regime & $22,12^{* *}$ & 0,55 & $6,54^{* *}$ & $2,01^{* *}$ & $7,98^{* *}$ \\
Reg x Pla & 1,25 & 0,73 & 1,6 & 0,81 & 1,61 \\
& \multicolumn{7}{c}{ Micronutrientes } \\
\hline
\end{tabular}




\begin{tabular}{|c|c|c|c|c|c|}
\hline & $\mathbf{F e}$ & B & $\mathrm{Cu}$ & Mn & $\mathbf{Z n}$ \\
\hline $\begin{array}{l}\text { Planta de } \\
\text { cobertura }\end{array}$ & 0,56 & $182,53 * *$ & 3,18 & $6,92 *$ & $13,39 * *$ \\
\hline Regime & $6,83^{* *}$ & $20,6^{* *}$ & 2,49 & 2,59 & $24,34 * *$ \\
\hline Reg x Pla & 0,67 & $6,27 * *$ & 1,17 & 1,82 & $5,37 * *$ \\
\hline \multicolumn{6}{|c|}{ Acúmulo } \\
\hline \multicolumn{6}{|c|}{ Macronutrientes } \\
\hline & $\mathbf{P}$ & $\mathbf{K}$ & $\mathbf{C a}$ & Mg & $\mathbf{S}$ \\
\hline $\begin{array}{l}\text { Planta de } \\
\text { cobertura }\end{array}$ & $21,66^{* *}$ & $8,75^{*}$ & $36,12 * *$ & $35,40 * *$ & $12,42 * *$ \\
\hline Regime & $160,65 * *$ & $7,84 * *$ & $14,33 * *$ & $17,59 * *$ & $14,85^{* *}$ \\
\hline Reg x plan & $2,82 *$ & 0,56 & $2,84 *$ & 2,19 & 1,68 \\
\hline \multicolumn{6}{|c|}{ Micronutrientes } \\
\hline & $\mathbf{F e}$ & B & $\mathbf{C u}$ & Mn & $\mathbf{Z n}$ \\
\hline $\begin{array}{l}\text { Planta de } \\
\text { cobertura }\end{array}$ & $10,69^{*}$ & $68,41 * *$ & $6,59 *$ & 4,79 & $5,59 *$ \\
\hline Regime & 0,26 & $27,23 * *$ & $5,86^{*}$ & 2,25 & $37,56 * *$ \\
\hline $\operatorname{Reg} x$ Plan & 0,72 & $7,51 * *$ & 0,25 & $2,50 * *$ & $3,87 *$ \\
\hline
\end{tabular}

$\mathrm{O}$ efeito isolado do fator planta de cobertura nos teores dos macronutrientes mostrou que o amaranto foi a espécie que apresentou os maiores teores de $\mathrm{P}, \mathrm{Ca}, \mathrm{Mg}$ e $\mathrm{S}$ (Tabela 5.6). A quinoa foi a planta de cobertura que apresentou o maior teor de K (49,75 $\left.\mathrm{g} \mathrm{kg}^{-1}\right)$. O milheto apresentou os menores teores dos macronutrientes, exceto para $\mathrm{P}(2,250$ $\mathrm{g} \mathrm{kg}^{-1}$ ), que apresentou teores semelhantes ao da quinoa. Prado e Vidal (2008) encontraram teores de $\mathrm{P}$ no milheto iguais a 3,3 $\mathrm{g} \mathrm{kg}^{-1}$ e Cazzeta et al., (2005) 2,2 $\mathrm{g} \mathrm{kg}^{-1}$.

Quanto ao teor dos micronutrientes Fe e Mn, apenas para o Mn houve diferença significativa entre as plantas de cobertura e o milheto apresentou os menores valores, o amaranto e a quinoa apresentaram os maiores teores desse elemento, não diferindo estatisticamente entre si.

O regime hídrico afetou os teores dos nutrientes $\mathrm{P}, \mathrm{Ca}, \mathrm{Mg}$ e S e Fe (Tabela 5.6). De maneira geral, o aumento da lâmina de água aplicada promoveu aumentos dos teores desses nutrientes. Esses resultados corroboram, em parte, com os encontrados por Crusciol et al., (2001), Crusciol et al., (2003), Medeiros et al., (2005), Scalco et al., (2013) os quais obtiveram aumento na absorção de $\mathrm{Ca}, \mathrm{Mg}$ e $\mathrm{P}$ por plantas de arroz e café, à medida que se aumentaram os níveis de água. Isso é explicado pelo fato de que a movimentação desses nutrientes no solo se dá predominantemente pelos processos de fluxo de massa e difusão, que tem a água como principal veículo. Costa et al., (2006) em 
estudo sobre o fluxo difusivo de $\mathrm{P}$ em função da umidade do solo observaram que a difusão desse nutriente aumentou com o acréscimo no conteúdo de água no solo. Portanto, o aumento na disponibilidade hídrica do solo favorece a absorção desses nutrientes. Esse fato também pode ser explicado pelo motivo de que a absorção desses nutrientes está ligada diretamente com o desenvolvimento das raízes, pois o crescimento das mesmas está diretamente influenciado pela disponibilidade hídrica no solo. Plantas com maior superfície radicular possuem maior capacidade para absorção de nutrientes (Marcante et al., 2011). Além do mais, plantas cultivadas com maior disponibilidade hídrica apresentam maior eficiência fotossintética, taxa de respiração e transpiração, resultando na maior absorção de nutrientes (Stone et al., 2002).

Comportamento diferente foi observado para o micronutriente Fe que teve o teor reduzido drasticamente com o aumento do regime hídrico. Essa redução nos teores de $\mathrm{Fe}$ pode ser resultante de um efeito de diluição.

Tabela 5.6 - Efeito isolado dos fatores plantas de cobertura e regime hídrico nos teores médios de macro e micronutrientes.

\begin{tabular}{|c|c|c|c|c|c|c|c|}
\hline $\begin{array}{l}\text { Planta de } \\
\text { cobertura }\end{array}$ & $\mathrm{P}$ & $\mathrm{K}$ & $\mathrm{Ca}$ & $\mathrm{Mg}$ & $\mathrm{S}$ & $\mathrm{Fe}$ & Mn \\
\hline \multicolumn{8}{|c|}{ Fator planta de cobertura } \\
\hline & \multicolumn{4}{|c|}{$\mathrm{g} / \mathrm{kg}$} & \multicolumn{3}{|c|}{$\mathrm{mg} / \mathrm{kg}$} \\
\hline Amaranto & $2,945 \mathrm{a}$ & $39,91 \mathrm{~b}$ & $12,833 \mathrm{a}$ & $3,068 \mathrm{a}$ & $4,148 \mathrm{a}$ & 234,44 & $17,01 \mathrm{a}$ \\
\hline Milheto & $2,250 \mathrm{~b}$ & $20,6 \mathrm{c}$ & $3,419 \mathrm{c}$ & $1,316 \mathrm{c}$ & $2,144 \mathrm{c}$ & 152,77 & $11,88 \mathrm{~b}$ \\
\hline Quinoa & $2,252 \mathrm{~b}$ & $49,75 \mathrm{a}$ & $7,226 b$ & $2,498 \mathrm{~b}$ & $3,093 \mathrm{~b}$ & 239,23 & $17,53 \mathrm{a}$ \\
\hline \multicolumn{8}{|c|}{ Fator lâmina de irrigação } \\
\hline 167 & $1,681 \mathrm{c}$ & 34,72 & $6,823 \mathrm{c}$ & $2,154 \mathrm{~b}$ & $2,679 \mathrm{c}$ & $284,94 \mathrm{a}$ & 18,01 \\
\hline 268 & $2,327 \mathrm{~b}$ & 37,56 & $7,797 \mathrm{~b}$ & $2,273 \mathrm{ab}$ & $2,841 \mathrm{~b}$ & $204,5 \mathrm{~b}$ & 15,23 \\
\hline 381 & $2,982 \mathrm{a}$ & 37,87 & $7,774 \mathrm{~b}$ & $2,299 \mathrm{ab}$ & $3,321 \mathrm{a}$ & $166,34 \mathrm{~b}$ & 13,28 \\
\hline 432 & $2,938 \mathrm{a}$ & 36,85 & $8,911 \mathrm{a}$ & $2,4517 \mathrm{a}$ & $3,673 \mathrm{a}$ & $179,47 \mathrm{~b}$ & 15,37 \\
\hline
\end{tabular}

Médias seguidas pelas mesmas letras para planta de cobertura e regime hídrico não diferem entre si pelo teste de Tukey ao nível de 5\%.

Os teores de boro foram maiores no amaranto em todas os regimes hídricos (Tabela 5.7) e o milheto foi a espécie com menor teor desse elemento, além disso o regime hídrico não influenciou nos teores de B nessa última espécie. No amaranto e quinoa houve aumento significativo desse elemento quando se aumentou a disponibilidade hídrica. Com relação ao Zn, a quinoa, apresentou os maiores teores desse nutriente nos dois regimes hídricos inferiores, e foi semelhante ao amaranto nos superiores. O milheto, novamente, foi a espécie com menor teor desse elemento. 
Tabela 5.7: Desdobramento da interação de regime hídrico e plantas de cobertura referente ao teor de Boro (B) e Zinco ( $\mathrm{Zn})$ na parte aérea das plantas.

\begin{tabular}{cccc}
\hline $\begin{array}{c}\text { Regime } \\
\text { hídrico } \\
(\mathrm{mm})\end{array}$ & Amaranto & Milheto \\
\cline { 2 - 4 } & \multicolumn{3}{c}{$\mathrm{B}\left(\mathrm{g} \mathrm{kg}^{-1}\right)$} \\
167 & $5,77 \mathrm{Ac}$ & $1,77 \mathrm{Ca}$ & Quinoa \\
268 & $8,20 \mathrm{Ab}$ & $1,89 \mathrm{Ca}$ & $5,79 \mathrm{Bb}$ \\
381 & $9,35 \mathrm{Ab}$ & $2,61 \mathrm{Ca}$ & $5,97 \mathrm{Bb}$ \\
432 & $11,36 \mathrm{Aa}$ & $2,17 \mathrm{Ca}$ & $7,52 \mathrm{Ba}$ \\
& & $7,60 \mathrm{Ba}$ \\
167 & $9,21 \mathrm{Bc}$ & $\left.7 \mathrm{~g} \mathrm{~kg}^{-1}\right)$ & \\
268 & $13,71 \mathrm{Bb}$ & $9,78 \mathrm{Cab}$ & $14,44 \mathrm{Ab}$ \\
381 & $15,21 \mathrm{Ab}$ & $12,73 \mathrm{Ba}$ & $18,26 \mathrm{Aa}$ \\
432 & $21,96 \mathrm{Aa}$ & $12,43 \mathrm{Ba}$ & $18,01 \mathrm{Aa}$ \\
\hline
\end{tabular}

Médias seguidas pelas mesmas letras, maiúsculas nas linhas e minúsculas nas colunas, não diferem entre si pelo teste de Tukey ao nível de 5\%.

\section{Acúmulo de macro e micronutrientes na parte aérea}

$\mathrm{O}$ aumento da disponibilidade hídrica proporcionou maior acúmulo de $\mathrm{P}, \mathrm{Ca} \mathrm{B}$ e Zn na parte aérea das três espécies estudadas (Tabela 5.8). O amaranto destacou-se no acúmulo de $\mathrm{P}, \mathrm{Ca}$, em todos os regimes o que evidencia a importância dessa espécie na ciclagem desses nutrientes. Outro fator a se destacar é a importância do Ca para o crescimento do sistema radicular, favorecendo assim a absorção e acúmulo de maiores quantidades dos demais nutrientes. Para o $\mathrm{Zn}$ o amaranto apresentou maiores valores apenas no maior regime hídrico. Resultados diferentes foram observados por outros autores, os quais encontraram, em estudos na região do Cerrado, maiores teores de $\mathrm{P}$ e Ca no milheto quando comparado ao amaranto (Boer et al., 2007; Pittelkow et al., 2012). Já para o acúmulo de Zn, Pittelkow et al., (2012) encontraram valores semelhantes no amaranto e milheto.

A quinoa foi a espécie que menos acumulou $P$, exceto na lâmina $432 \mathrm{~mm}$, que não se diferiu estatisticamente do milheto. $\mathrm{O}$ menor acúmulo desse nutriente na quinoa é resultado da sua menor produção de massa seca quando comparada as outras duas espécies (Figura 5.2). Conforme citado por Boer et al. (2007), a quantidade de um determinado nutriente acumulado em uma planta depende da espécie utilizada e da produção de fitomassa seca produzida. Resultados semelhantes foram obtidos por Perin 
et al. (2010), que observaram menores teores de $\mathrm{P}$ nas espécies com menor produção de biomassa seca. O acumulo de $\mathrm{B}$ foi menor no milheto. Embora o milheto tenha apresentado produção de biomassa seca semelhante ao amaranto e superior a quinoa (Figura 5.2), o menor acúmulo de B em relação as demais espécies é justificado pelo menor teor desse elemento na parte aérea, conforme apresentado na Tabela 5.8. Para Ca e Zn, a quinoa e o milheto apresentaram resultados semelhantes, exceto na lâmina 432 mm em que a quinoa acumulou maior quantidade desses nutrientes.

Tabela 5.8: Desdobramento da interação do regime hídrico e plantas de cobertura referente ao acúmulo de Fósforo (P), Cálcio (Ca), Boro (B) e Zinco (Zn) na parte aérea das plantas.

\begin{tabular}{cccc}
\hline $\begin{array}{c}\text { Regime } \\
\text { hídrico } \\
(\mathrm{mm})\end{array}$ & \multicolumn{3}{c}{ Planta de cobertura } \\
\cline { 2 - 4 } & Amaranto & Milheto & Quinoa \\
167 & $19,68 \mathrm{Ac}$ & $\mathrm{P}\left(\mathrm{kg} \mathrm{ha}^{-1}\right)$ & $9,71 \mathrm{Cc}$ \\
268 & $40,88 \mathrm{Ab}$ & $28,25 \mathrm{Ab}$ & $20,99 \mathrm{Bb}$ \\
381 & $53,04 \mathrm{Aa}$ & $42,19 \mathrm{Ba}$ & $29,33 \mathrm{Cab}$ \\
432 & $51,22 \mathrm{Aab}$ & $36,05 \mathrm{Bab}$ & $33,19 \mathrm{Ba}$ \\
& & $\mathrm{Ca}\left(\mathrm{kg} \mathrm{ha}^{-1}\right)$ & $38,91 \mathrm{Bb}$ \\
167 & $108,3 \mathrm{Ac}$ & $32,71 \mathrm{Bb}$ & $69,94 \mathrm{Bab}$ \\
268 & $183,69 \mathrm{Ab}$ & $49,26 \mathrm{Ba}$ & $83,11 \mathrm{Ba}$ \\
381 & $193,29 \mathrm{Aab}$ & $55,55 \mathrm{Ba}$ & $103,85 \mathrm{Ba}$ \\
432 & $221,89 \mathrm{Aa}$ & $45,75 \mathrm{Ca}$ & $0,049 \mathrm{Ac}$ \\
& & $\mathrm{B}\left(\mathrm{kg} \mathrm{ha}^{-1}\right)$ & $0,057 \mathrm{Bbc}$ \\
167 & $0,057 \mathrm{Ac}$ & $0,022 \mathrm{Ba}$ & $0,085 \mathrm{Ba}$ \\
268 & $0,122 \mathrm{Ab}$ & $0,027 \mathrm{Ca}$ & $0,092 \mathrm{Ba}$ \\
381 & $0,150 \mathrm{Aa}$ & $0,035 \mathrm{Ca}$ & $0,095 \mathrm{Ab}$ \\
432 & $0,170 \mathrm{Aa}$ & $0,027 \mathrm{Ca}$ & $0,177 \mathrm{Aa}$ \\
& & $\mathrm{Zn}\left(\mathrm{kg} \mathrm{ha}^{-1}\right)$ & $0,212 \mathrm{Aa}$ \\
167 & $0,090 \mathrm{Ac}$ & $0,090 \mathrm{Ab}$ & $0,220 \mathrm{Ba}$ \\
268 & $0,190 \mathrm{Ab}$ & $0,137 \mathrm{Aab}$ & $0,172 \mathrm{Aa}$ \\
381 & $0,245 \mathrm{Ab}$ & $0,165 \mathrm{Ca}$ & \\
432 & $0,327 \mathrm{Aa}$ & &
\end{tabular}

Médias seguidas pelas mesmas letras, maiúsculas nas linhas e minúsculas nas colunas, não diferem entre si pelo teste de Tukey ao nível de 5\%.

O efeito isolado dos fatores lâmina e espécie de planta mostrou que o amaranto se destacou também no acúmulo de $\mathrm{K}, \mathrm{Mg}, \mathrm{S}, \mathrm{Fe}, \mathrm{Cu}$ e $\mathrm{Mn}$ (Tabela 5.9). O milheto foi a espécie que menos acumulou K e Mg. Pittelkow et al., (2012) também encontraram maior acúmulo de $\mathrm{K}$ no amaranto $\left(144,5 \mathrm{~kg} \mathrm{ha}^{-1}\right)$ do que no milheto $\left(108,9 \mathrm{~kg} \mathrm{ha}^{-1}\right)$. Teixeira et 
al., (2008) ao avaliar o milheto aos 119 DAP observaram acúmulo de 0,027; 0,28; 0,0016 $\mathrm{kg} \mathrm{ha}^{-1} \mathrm{Cu}, \mathrm{Mn}$ e Fe. Apesar de, em geral, a quinoa apresentar menor acúmulo de nutrientes, esta espécie possui elevada capacidade de acumular K (502,78 ha-1). Quanto ao efeito do regime hídrico, de maneira geral houve aumento significativo no acúmulo desses elementos com o aumento da disponibilidade hídrica.

Tabela 5.9 - Efeito isolado dos fatores plantas de cobertura e do regime hídrico no acúmulo de macro e micronutrientes.

\begin{tabular}{|c|c|c|c|c|c|c|}
\hline $\begin{array}{l}\text { Planta de } \\
\text { cobertura }\end{array}$ & K & $\mathrm{Mg}$ & $S$ & $\mathrm{Fe}$ & $\mathrm{Cu}$ & $\mathrm{Mn}$ \\
\hline \multicolumn{7}{|c|}{ Planta de cobertura } \\
\hline \multicolumn{7}{|c|}{$\mathrm{kg} \mathrm{ha}^{-1}$} \\
\hline Amaranto & $562,62 \mathrm{a}$ & $41,96 \mathrm{a}$ & 58,96 a & $3,08 \mathrm{a}$ & $0,04 \mathrm{ab}$ & $0,22 \mathrm{a}$ \\
\hline Milheto & $273,84 \mathrm{c}$ & $17,58 \mathrm{c}$ & $28,72 \mathrm{~b}$ & $2,00 \mathrm{~b}$ & $0,05 \mathrm{a}$ & $0,15 \mathrm{~b}$ \\
\hline Quinoa & $502,78 \mathrm{~b}$ & $25,45 \mathrm{~b}$ & $31,73 b$ & $2,25 \mathrm{~b}$ & $0,02 \mathrm{~b}$ & $0,17 a b$ \\
\hline \multicolumn{7}{|c|}{ Regime hídrico (mm) } \\
\hline 167 & $304,54 \mathrm{~b}$ & $18,7 \mathrm{~b}$ & $24,64 \mathrm{c}$ & 2,49 & $0,02 \mathrm{c}$ & $0,15 b$ \\
\hline 268 & $462,34 \mathrm{a}$ & $29,05 \mathrm{a}$ & $37,14 \mathrm{~b}$ & 2,58 & $0,03 \mathrm{bc}$ & $0,17 \mathrm{ab}$ \\
\hline 381 & 519,49 a & $32,02 \mathrm{a}$ & $46,84 \mathrm{a}$ & 2,27 & $0,04 \mathrm{ab}$ & $0,18 a b$ \\
\hline 432 & $499,27 \mathrm{a}$ & $33,56 \mathrm{a}$ & $50,59 \mathrm{a}$ & 2,43 & $0,05 \mathrm{a}$ & $0,21 \mathrm{a}$ \\
\hline
\end{tabular}

Médias seguidas pelas mesmas letras, maiúsculas nas linhas e minúsculas nas colunas, não diferem entre si pelo teste de Tukey ao nível de 5\%.

Pode-se verificar, portanto que dependendo da espécie e do regime hídrico que houveram alterações nos teores e acúmulo de diversos macro e micronutrientes o que deve afetar a micro e meso fauna qualitativamente e quantitativamente, que por sua vez pode afetar os agregados do solo e ciclagem de nutrientes. Esta dinâmica afeta a necessidade de manejo tanto de adubação quando do manejo de matéria orgânica de modo que os nutrientes fiquem disponíveis também para a próxima cultura no momento de maior necessidade.

\section{Produtividade de grãos}

$\mathrm{Na}$ avaliação da produtividade de grãos houve interação significativa entre espécies (amaranto e quinoa) e regimes hídricos (Tabela 5.10) e o milheto não produziu grãos. Condições de baixas temperaturas $\left(13\right.$ a $\left.16^{\circ} \mathrm{C}\right)$ pode favorecer o aparecimento de plantas estéreis dessa espécie (Mashingaidze e Muchena, 1982). Oliveira (2016) 
avaliando o desempenho de plantas de cobertura na região Centro Oeste, no período compreendido entre maio e outubro, observou 115 horas de temperaturas inferiores a $16^{\circ} \mathrm{C}$, fator este que impediu a produção de grãos do milheto.

De maneira geral, houve aumento da produtividade do amaranto e da quinoa com o aumento da disponibilidade hídrica. Em relação as espécies, o amaranto produziu maior quantidade de grãos nos regimes de 268 e $381 \mathrm{~mm}$, não diferindo estatisticamente da quinoa nos demais regimes. A maior produtividade para o amaranto $\left(3866,89 \mathrm{Kg} \mathrm{ha}^{-1}\right)$ foi observada no regime de $381 \mathrm{~mm}$. Ferreira et al., (2014), em estudo com diferentes doses de $\mathrm{N}$ e densidades de plantio do amaranto na região do cerrado, obteve produtividades de até $3692,50 \mathrm{Kg} \mathrm{ha}^{-1}$. Já Erasmo et al., (2004), em análise de diferentes cultivares de amaranto no Sul do Tocantins, encontraram produtividades máximas de $990 \mathrm{Kg} \mathrm{ha}^{-1}$.

Tabela 5.10 - Desdobramento da interação do regime hídrico e plantas de cobertura referente a produtividade de grãos.

\begin{tabular}{|c|c|c|}
\hline \multirow{2}{*}{$\begin{array}{l}\text { Regime hídrico } \\
(\mathrm{mm})\end{array}$} & \multicolumn{2}{|c|}{ Planta de cobertura } \\
\hline & Quinoa & Amaranto \\
\hline & \multicolumn{2}{|c|}{$\mathrm{Kg} \mathrm{ha}^{-1}$} \\
\hline 167 & $691,58 \mathrm{Ac}$ & $1018,43 \mathrm{Ac}$ \\
\hline 268 & $1904,31 \mathrm{Bb}$ & $2875,02 \mathrm{Ab}$ \\
\hline 381 & $2882,90 \mathrm{Ba}$ & $3866,89 \mathrm{Aa}$ \\
\hline 432 & $3488,86 \mathrm{Aa}$ & $3549,45 \mathrm{Aa}$ \\
\hline
\end{tabular}

Médias seguidas pelas mesmas letras, maiúsculas nas linhas e minúsculas nas colunas, não diferem entre si pelo teste de Tukey ao nível de $5 \%$

\subsection{CONCLUSÕES}

Em condições de adequado suprimento de água, levando em consideração a variável produção de biomassa fresca, o cultivo do amaranto, mostrou-se melhor opção que o cultivo das demais espécies estudadas por apresentar maior biomassa fresca. Quanto a produção de biomassa seca as menores médias foram observadas na quinoa.

De maneira geral, o amaranto foi a espécie com maior teor e acúmulo de macro e micronutrientes e o milheto foi a espécie que apresentou os menores.

O elevado potencial de produção de grãos, associado a outras características como produção de biomassa e acúmulo de nutrientes, pode determinar a inclusão do amaranto no sistema de plantio direto. A quinoa, devido a sua maior capacidade de acúmulo de 
nutrientes que o milheto e seu elevado potencial de produção de grãos também pode ser uma alternativa ao milheto.

\subsection{REFERÊNCIAS BIBLIOGRÁFICAS}

ACOSTA, J.A.A; AMADO, T.J.C; SILVA, L.S; SANTI, A; WEBER, M.A. Decomposição da fitomassa de plantas de cobertura e liberação de nitrogênio em função da quantidade de resíduos aportada ao solo sob sistema plantio direto. Ciência Rural, Santa Maria, v. 44, p. 801-809, 2014.

ALVARENGA, R. C.; LARA CABEZAS, W. A. R.; CRUZ, J. C.; SANTANA, D. P. Plantas de cobertura de solo para sistema plantio direto. Informe Agropecuário, Belo Horizonte, MG, v. 22, n. 208, p. 25-36, 2001.

BAYER, C. Dinâmica da matéria orgânica em sistemas de manejo de solos. Porto Alegre, RS: Universidade Federal do Rio Grande do Sul, 1996. 241p. Tese (Tese de Doutorado), Universidade Federal do Rio Grande do Sul, 1996.

BOER, C. A; ASSIS, R.L; SILVA, G.P; BRAZ, A.J.B.P; BARROSO, A.L.L; CARGNELLUTI FILHO, A; PIRES, F.R. Biomassa, decomposição e cobertura do solo ocasionada por resíduos culturais de três espécies vegetais na região Centro-Oeste do Brasil. Revista Brasileira de Ciência do Solo, Viçosa, v. 32, n. 2, p. 843-851, 2008.

BOER, C.A; ASSIS, R.L; SILVA, G.P; BRAZ, A.J.B.P; BARROSO, A.L.L; CARGNELUTTI FILHO, A.C; PIRES, F.R. Ciclagem de nutrientes por plantas de cobertura na entressafra em um solo de cerrado. Pesquisa Agropecuária Brasileira, v. 42, n. 9, p. 1269-1276, 2007.

BORGES, W.L.B; FREITAS, R.S; MATEUS, G.P; SÁ, M.E; ALVES, M.C. Plantas de cobertura para o noroeste do estado de São Paulo. Ciência Rural, Santa Maria, v. 45, n. 5, p. 799-805, 2015.

BRESSAN, S.B; NOBREGA, J.C.A; NOBREGA, R.S.A; BARBOSA, R.S; SOUSA, L.B. Plantas de cobertura e qualidade química de latossolo amarelo sob plantio direto no cerrado maranhense. Revista Brasileira de Engenharia Agricola e Ambiental, Campina Grande, v. 17, n. 4, p. 371-378, 2013.

CARVALHO, A.M; COSER, T.R; REIN, T.A; DANTAS, R.A; SILVA, R.R; SOUZA, K.W. Manejo de plantas de cobertura na floração e na maturação fisiológica e seu efeito na produtividade de milho. Pesquisa Agropecuária Brasileira, v.50, n.7, p.551-561, 2015.

CARVALHO, A.M.; BUSTAMANTE, M.M.C.; SOUSA JUNIOR, J.G.A.; VIVALDI, L.J. Decomposição de resíduos vegetais em Latossolo sob cultivo de milho e plantas de cobertura. Revista Brasileira de Ciência do Solo, v.32, p.2831-2838, 2008. 
CAZETTA, D. A.; FORNASIERI FILHO, D.; GIROTTO, F. Composição, produção de matéria seca e cobertura do solo em cultivo exclusivo e consorciado de milheto e crotalária. Acta Scientiarum Agronomy, Maringa, v. 27, p. 575-580, 2005.

COSTA, N.R; ANDREOTTI, M; ULIAN, N.A; COSTA, B.S; PARIZ, C.M; TEIXEIRA FILHO, M.C.M. Acúmulo de nutrientes e tempo de decomposição da palhada de espécies forrageiras em função de épocas de semeadura. Biosci, J., Uberlândia, v.31, n.3, p. 818$829,2015$.

COSTA, J.P.V; BARROS, N.F; ALBUQUERQUE, A.W; MOURA FILHO, G; SANTOS, J.R. Fluxo difusivo de Fósforo em função de doses e da umidade do solo. Revista Brasileira de Engenharia Agrícola e Ambiental, Campina Grande, v.10, n.4, p. 828-835, 2006.

CRUSCIOL, C. A. C. Crescimento radicular, nutrição e produção de cultivares de arroz de terras altas em função da disponibilidade hídrica e de fósforo. 2001. $111 \mathrm{f}$. Tese (Livre docência) - Universidade Estadual Paulista, Botucatu, 2001.

CRUSCIOL, C.A.C; ARF, O; SORATTO, R.P; MACHADO, J.R. Influência das lâminas de água e adubação mineral na nutrição e produtividade de arroz de terras altas. Revista Brasileira de Ciencia do Solo. v. 27, p. 647-654, 2003.

EMBRAPA. Programa de monitoramento da irrigação.Brasília: EMBRAPA, 2012. Disponível em : : <http://hidro.cpac.embrapa.br/index.php >. Acesso em:15 ago 2015.

ERASMO, E.A.L; DOMINGOS, V.D; SPEHAR, C.R; DIDONET, J; SARMENTO, R.A; CUNHA, A.M. Avaliação de cultivares de amaranto em sistema plantio direto no sul do Tocantins. Biosci J., Uberlândia, v.20, n.1, p. 171-176, 2004.

ESPÍNDOLA, J.A.A. et al. Decomposição e liberação de nutrientes acumulados em leguminosas herbáceas perenes consorciadas com bananeira. Revista Brasileira de Ciência do Solo, v.30, p.321- 328, 2006

FAGERIA, N.K.; SANT'ANA, E.P. \& MORAIS, O.P. Resposta de genótipos de arroz de sequeiro favorecido à fertilidade do solo. Pesq. Agropec. Bras., 30:1155-1161, 1995.

FERREIRA, C.C; RIBEIRO JUNIOR, W.Q; RAMOS, M.L.G; SPEHAR, C.R; FARIAS, T.R.R. Efeito da densidade de semeadura e doses de nitrogênio sobre a produtividade e biometria de amaranto, no Cerrado do planalto central. Biosci. J, Uberlândia, v. 30, supplement 2, p. 534-546, 2014.

JUNIOR RAMOS, E.U; MACHADO, R.A.F; OLIBONE, D; CASTOLDI, G; RAMOS, B.M. Crescimento de plantas de cobertura sob déficit hídrico. Semina: Ciências agrárias, Londrina, v.34, n.1, p.47-56, 2013.

LIMA, L.B; PETTER, F.A; LEANDRO, W.M. Desempenho de plantas de cobertura sob níveis de compactação em Latossolo Vermelho de Cerrado. Revista Brasileira de Engenharia Agrícola e Ambiental, Campina Grande - PB, v. 19, n. 11, p. 1064-1071, 2015. 
MARCANTE, N.C; CAMACHO, M.A; PAREDES, F.P.J. Teores de nutrientes no milheto como cobertura do solo. Biosci J., Uberlândia, v. 27, n.2, p. 196-204, 2011.

NOZAKI, M. H.; VENDRÚSCULO, M. Características químicas e densidade global de um latossolo vermelho eutróferrico cultivado com plantas de cobertura em Toledo-PR. Semina: Ciências Agrárias, Londrina, v. 31, p. 1245-1252, 2010.

PACHECO, L. P; LEANDRO, W.M; MACHADO, P.L.O.A; ASSIS, R.L; COBUCCI, T; MADARI, B.E; PETTER, F.A. Produção de fitomassa e acúmulo e liberação de nutrientes por plantas de cobertura na safrinha. Pesquisa Agropecuária Brasileira, Brasília, v. 46, n. 1, p. 17-25, 2011.

PERIN, A; SANTOS, R.H.S; CABALLERO, S.S.U; GUERRA, J.G.M; GUSMÃO, L.A. Acúmulo e liberação de $\mathrm{P}, \mathrm{K}, \mathrm{Ca}$ e $\mathrm{Mg}$ em crotalária e milheto solteiro e consorciados. Ceres, Viçosa, v.57, n.2, p. 274-281, 2010.

PITTELKOW, F.K; SCARAMUZZA, J.F; WEBER, O.L.S; MARASCHIN, L; VALADÃO, F.C.A; OLIVEIRA, E.S. Produção de biomassa e acumulo de nutrientes em plantas de cobertura sob diferentes sistemas de preparo do solo. Agrarian, Dourados, v.5, n.17, p. 212-222, 2012.

PRADO, R. de M.; VIDAL, A. A. Efeitos da omissão de macronutrientes em solução nutritiva sobre o crescimento e a nutrição do milheto. Pesquisa Agropecuária Tropical, Goiânia, v. 38, n. 3, p. 208-214, 2008

SCALCO, M.S; ALVARENGA, L.A; GUIMARÃES, R.J; DOMINGHETI, A.W; COLOMBO, A; ASSIS, G.A; ABREU, G.F. Teores foliares de fósforo e zinco , produtividade e crescimento do café irrigado. Pesq. Agropec. Bras., Brasilia, v.49, n.2, p.95-111, 2014.

SILVA, J.A.N.; SOUZA, C.M.A.; SILVA, C.J.; BOTTEGA, S.P. Crescimento e produção de espécies forrageiras consorciadas com pinhão-manso. Pesquisa Agropecuária Brasileira, v.47, p.769-775, 2012.

SORATTO, R.P; CRUSCIOL, C.A.C; COSTA, C.H.M; FERRARI NETO, J; CASTRO, G.S.A. Produção, decomposição e ciclagem de nutrientes em resíduos de crotalária e milheto, cultivados solteiros e consorciados. Pesquisa Agropecuária Brasileira, Brasília, V. 47, n. 10, p. 1462-1470, 2012.

STONE, L. F.; GUIMARÃES, C. M.; MOREIRA, J. A. A. Compactação do solo na cultura do feijoeiro: I. nas propriedades físico-hídricas do solo. Revista Brasileira de Engenharia Agrícola e Ambiental, Campina Grande, v. 6, n. 2, p. 213-218, maio/ago. 2002.

SPEHAR, C.R; CABEZAS, W.A.R.L. Introdução e seleção de espécies para diversificação do sistema produtivo no cerrado. In CABEZAS, W.A.R.L.; FREITAS, P.L, (Eds.). Plantio direto na integração lavoura pecuária, Uberlândia, MG:UFU. 2001. p 179-188. 
SPEHAR, C.R; TRECENTI, R. Desempenho agronômico de espécies tradicionais e inovadoras da agricultura em semeadura de sucessão e entressafra no cerrado do planalto central brasileiro. Biosc, J., v. 27; n.1, 2011.

SPEHAR, C. R. Production systems in the savannas of Brazil: Key factors to sustainability. In: LAL, R. (Ed.). Soil Quality and Agricultural Sustainability. Ann Arbor Press, Chelsea, Michigan. 1998. p. 301-318. 1998.

SPEHAR, C. R. Quinoa: alternativa para a diversificação agrícola e alimentar. Planaltina: Embrapa Cerrados, 2007. 103p

TEIXEIRA, C.M.; CARVALHO, G.J.; ANDRADE, M.J.B.; FURTINI NETO, A.E. Biomassa, teor e acúmulo de micronutrientes do milheto, feijão-de porco e guanduanão, em cultivo solteiro e consorciado. Acta Scientiarum Agronomy, v.30, p.533$538,2008$.

TORRES, J.L.R; CUNHA, M.A; PEREIRA, M.G; VIEIRA, D.M.S. Cultivo de feijão e milho em sucessão a plantas de cobertura. Revista Caatinga, v. 27, n. 4, p. 117-125, 2014.

TORRES, J. L. R. et al. Produtividade de feijão so-bre lâminas de irrigação e Coberturas de solo. Bioscience Journal, Uberlândia, v. 29, n. 4, p. 833-841, 2013.

WROBEL, F.L; NEUMANN,M; LEAL, G.F.M; HORST, E.H; UENO, R.K. Doses de nitrogênio sobre produtividade e aspectos nutricionais de grãos e palha de trigo duplo propósito. Revista acadêmica de ciências animais. V.14, p. 27-35, 2016.

ZIECH, A.R.D; CONCEIÇÃO, P.C; LUCHESE, A.V; BALIN, N.M; CANDIOTTO, G; GARMUS, T.G. Proteção do solo por plantas de cobertura de ciclo hibernal na região sul do Brasil. Pesquisa Agropecuária Brasileira, Brasilia, v.50, n. 5, p. 374-382, 2015. 
CAPITULO II

INFLUÊNCIA DE PLANTAS DE COBERTURA CULTIVADAS SOB REGIMES HÍDRICOS VARIÁVEIS NOS COMPONENTES MORFOLÓGICOS E PRODUTIVOS DO MILHO EM SUCESSÃO. 


\section{INFLUÊNCIA DE PLANTAS DE COBERTURA CULTIVADAS SOB REGIMES HÍDRICOS VARIÁVEIS NOS COMPONENTES MORFOLÓGICOS E PRODUTIVOS DO MILHO EM SUCESSÃO.}

\subsection{RESUMO}

O objetivo desse trabalho foi avaliar a influência de plantas de cobertura, cultivadas sob diferentes regimes hídricos, no milho cultivado em sucessão no Cerrado. O experimento foi desenvolvido em condições de campo, de maio de 2015 a março de 2016, na área experimental da Embrapa Cerrados, localizada no município de Planaltina - DF. Os tratamentos foram dispostos em blocos casualizados, com parcelas subdivididas e quatro repetições. As parcelas foram compostas por quatro regimes hídricos $(167 \mathrm{~mm} ; 268 \mathrm{~mm}$; $381 \mathrm{~mm} ; 432 \mathrm{~mm}$ ) e as subparcelas foram compostas pelas seguintes plantas de cobertura: amaranto "BRS Alegria" (Amaranthus cruentus), quinoa, "Genótipo derivado do BRS Piabiru" (Chenopodium quinoa, Wild) e milheto (Pennisetum glaucum). O experimento apresentou duas fases. A primeira foi iniciada em maio de 2015 com o término em setembro desse mesmo ano. Nessa fase, foram instaladas as plantas de cobertura. Na segunda fase (iniciada em novembro de 2015 e finalizada em março 2016) foi implantada a cultura do milho em sucessão as plantas de cobertura. Foram avaliados a produção de matéria seca e os teores de celulose e lignina das plantas de cobertura; os componentes morfológicos do milho (altura de planta, altura de inserção de espiga e diâmetro de colmo), os componentes produtivos (número de fileira de grãos na espiga, número de grãos por espiga, peso de mil grãos, peso médio de espiga, diâmetro de espiga) e a produtividade de grãos. Os regimes hídricos influenciaram a produção de matéria seca e os teores de lignina na parte aérea das plantas de cobertura. O regime hídrico aplicado às plantas de cobertura, bem como as diferentes espécies de plantas de cobertura, influenciou os atributos morfológicos (altura de plantas, altura de inserção de espiga e diâmetro de colmo) e alguns dos componentes produtivos (diâmetro de espiga e número de grãos por fileira) do milho cultivado em sucessão. As plantas de cobertura promoveram efeito semelhante na produtividade do milho em sucessão.

Palavras-chave: Zea mays, soil cover, water availability, Amaranthus cruentus, Chenopodium quinoa; Pennisetum glaucum

\subsection{ABSTRACT}

The objective of this work was to evaluate the influence of cover crops, grown under different water regimes, on maize grown in succession. The experiment was carried out under field conditions, from May, 2015 to March, 2016, in the experimental area of Embrapa Cerrados, located in the city of Planaltina - DF. The treatments were arranged in randomized blocks, with subdivided plots and four replications. The plots were composed of four water regimes $(167 \mathrm{~mm}, 268 \mathrm{~mm}, 381 \mathrm{~mm}, 432 \mathrm{~mm})$ and the subplots were composed of the following cover plants: BRS Alegria (Amaranthus cruentus), quinoa, "Genotype derived from BRS Piabiru "(Chenopodium quinoa, Wild) and millet 
(Pennisetum glaucum). The experiment had two phases. The first was initiated in May 2015 with the end of September of that year. In this phase, the hedge plants were installed. In the second phase (started in November of 2015 and finalized in March 2016) the maize crop was implanted in succession the plants of cover. The dry matter production and the cellulose and lignin contents of the cover plants were evaluated; The morphological components of the corn (plant height, spike insertion height and stalk diameter), the productive components (row number of grains on the spike, number of grains per spike, weight of a thousand grains, average ear weight, diameter Of spike) and grain yield were measured. The water regimes influenced dry matter production and lignin contents in the aerial part of the cover plants. The water regime applied to the cover plants, as well as the different species of cover plants, influenced the morphological attributes (plant height, spike insertion height and stalk diameter) and some of the productive components (spike diameter and number of plants). Grains per row) of maize grown in succession. Cover plants promoted a similar effect on maize productivity in succession.

Keywords: Zea mays, soil cover, water availability, Amaranthus cruentus, Chenopodium quinoa; Pennisetum glaucum

\subsection{INTRODUÇÃO}

O milho (Zea mays L.) é considerado uma das mais importantes e antigas culturas agrícolas (Alves e Amaral, 2011). O Brasil é o terceiro maior produtor mundial de milho (FAOSTAT, 2012), com cerca de 15,9 milhões de hectares cultivados, sendo 5,4 e 10,5 milhões de hectares e produtividade de 4.799 e $3.904 \mathrm{Kg} \mathrm{ha}^{-1}$ na primeira e segunda safra, respectivamente $(\mathrm{CONAB}, 2016)$. Aproximadamente, $70 \%$ da produção é destinada ao consumo interno, abastecendo principalmente as atividades de criação de animais e $30 \%$ são destinados as exportações (CONAB, 2014). A cultura do milho possui um alto potencial produtivo, alcançando $10 \mathrm{t} \mathrm{ha}^{-1}$ de grãos em condições experimentais e por agricultores que adotam tecnologia adequada (Carvalho et al., 2004).

O cultivo de plantas para a formação de cobertura do solo antes da instalação da cultura do milho poderá promover melhorias dos atributos físicos e químicos, aumentar a atividade microbiana, acúmulo de nutrientes e matéria orgânica nas camadas superficiais, além de poder exercer influência sobre a germinação e/ou no desenvolvimento da cultura e promover maiores rendimentos (Casali, 2012; Barros et al, 2013; Lima Filho et al.,2014). Alguns estudos na região do Cerrado têm demonstrado o efeito benéfico das plantas de cobertura antecedendo algumas culturas comerciais (Torres et al., 2013; Torres et al., 2014; Cardoso et al., 2014; Carvalho et al., 2015) e em aspectos morfológicos e produtivos do milho plantado em sucessão (Silva et al., 2008; Pacheco, et 
al., 2011, Carvalho et al., 2011). Tal fato pode ser atribuído a contínua liberação de nutrientes na superfície do solo após a decomposição dos seus resíduos (Pacheco et al., 2011; Carvalho et al., 2015) e por incrementar os teores de matéria orgânica, reduzir as variações de temperatura e evaporação da água do solo e manter o solo mais úmido, fatores que favorecem os cultivos subsequentes (Boer et al., 2008). Entretanto, alguns trabalhos não evidenciaram efeitos significativos de plantas de cobertura no milho em sucessão (Silva et al; Moreira et al; Moda et al, 2014). Portanto, a resposta da cultura do milho depende da planta de cobertura antecessora e das condições do local de cultivo.

Dentre as espécies utilizadas como planta de cobertura do solo, destaca-se o milheto (Pennisetum glaucum), apontado como uma das culturas responsáveis pela expansão do sistema de plantio direto (SPD) na região central do Brasil, por apresentar grande quantidade de biomassa, alta resistência à seca e ciclagem de nutrientes (Pacheco et al., 2011; Silva et al., 2010;). Uma alternativa para plantas de cobertura são os pseudocereais, que tem apresentado boa adaptação à região do Cerrados, dentre os quais estão o amaranto (Amaranthus cruentus) e a quinoa (Chenopodium quinoa Willd). $\mathrm{O}$ amaranto possui raiz pivotante e vigorosa, com abundante ramificação que cria condições favoráveis à absorção de água e nutrientes e por isso tem facilidade de se adaptar a regiões áridas ou em locais com período seco prolongado (Spehar, 2007). A quinoa é uma espécie que apresenta bom desenvolvimento em condições de limitações ambientais e apresenta estratégias de adaptação ao déficit hídrico, tanto fisiológico como morfológico (SILVA et al., 2014). A produção média de matéria seca está entre 7 e $12 \mathrm{t} \mathrm{ha}^{-1}$ para o milheto (Mechede et al., 2007); 6,7 e 9,1 $\mathrm{t} \mathrm{ha}^{-1}$ para o amaranto (Erasmo et al., 2004) e $7 \mathrm{t} \mathrm{ha}^{-1}$ para a quinoa (Rocha, 2008).

Um fator decisivo na escolha de planta de cobertura é conhecer a sua adaptação à região e sua habilidade em crescer num ambiente menos favorável (Alvarenga et al., 2001). A baixa disponibilidade hídrica pode ser considerada como o principal fator que afeta diretamente o desenvolvimento das plantas e produtividade das culturas (Coelho et al., 2010). A deficiência hídrica provoca alterações no vegetal cuja irreversibilidade vai depender de sua duração e severidade e do genótipo e estágio de desenvolvimento da planta (Santos; Calesso, 1998). Portanto, torna-se fundamental o estudo do comportamento, desenvolvimento e desempenho dessas plantas sob diferentes condições hídricas, para obtenção das espécies que melhor se adaptam a essas condições. 
Assim, o presente trabalho tem como objetivo avaliar a influência de plantas de cobertura, cultivadas sob regimes hídricos variáveis, no milho cultivado em sucessão.

\subsection{MATERIAL E MÉTODOS}

O experimento foi desenvolvido em campo, de maio de 2015 a março de 2016, na área experimental da Embrapa Cerrados, localizada no município de Planaltina - DF $\left(15^{\circ} 35^{\prime} 30 \mathrm{~S}, 47^{\circ} 42^{\prime} 30 \mathrm{~W}\right.$ e altitude de $\left.1.014 \mathrm{~m}\right)$. Segundo a classificação de Koppen, o clima da região é do tipo Aw (Koppen), com duas estações bem definidas (seca e chuvosa). Os totais mensais de precipitação e as médias mensais de temperatura mínima e máxima, durante o período experimental, estão apresentados na figura 6.1.

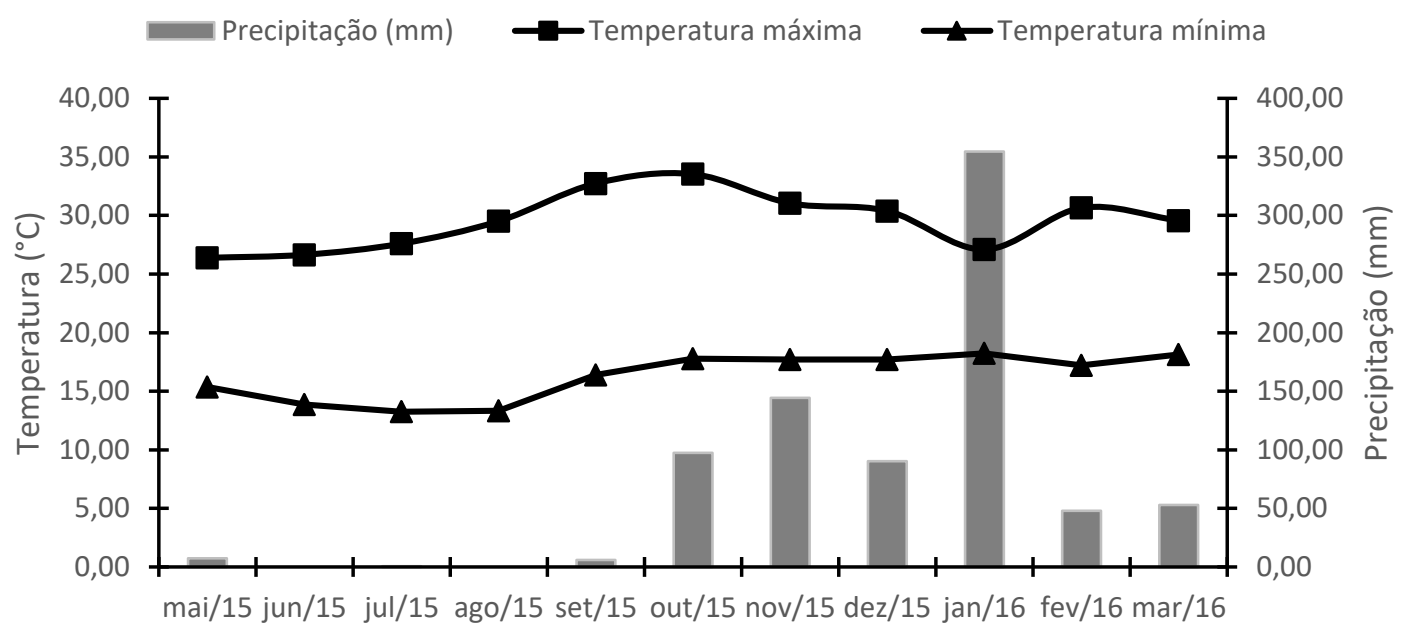

Figura 6.1: Precipitação pluviométrica e temperaturas máximas e mínimas ocorridas na área experimental entre os meses de maio de 2015 a março de 2016 em Planaltina - DF. *Dados obtidos da estação meteorológica localizada ao lado da área experimental.

O solo é classificado como Latossolo vermelho A moderado, textura argilosa, fase Cerrado, relevo plano (Santos et al., 2013). A análise química do solo antes da instalação do experimento está apresentada na tabela 6.1.

Tabela 7.1 - Análise química do solo da área experimental, nas profundidades de 0-10, 10-20, 20-30 cm, realizada em abril/2013.

\begin{tabular}{lllllllll}
\hline $\begin{array}{l}\text { Profundidade } \\
(\mathrm{cm})\end{array}$ & $\mathrm{Ph}$ & $\mathrm{Ca}$ & $\mathrm{Mg}$ & $\mathrm{K}$ & $\mathrm{H}+\mathrm{Al}$ & $\mathrm{P}$ & $\mathrm{S}$ & $\mathrm{M} . \mathrm{O}$ \\
\hline & $\begin{array}{l}\mathrm{em} \\
\text { água }\end{array}$ & $\mathrm{cmoc} / \mathrm{dm}^{3}$ & $\mathrm{cmoc} / \mathrm{dm}^{3}$ & & & & & \\
& & & $\mathrm{mg} / \mathrm{dm}^{3}$ & $\mathrm{cmoc} / \mathrm{dm}^{3}$ & $\mathrm{mg} / \mathrm{dm}^{3}$ & $\mathrm{mg} / \mathrm{kg}$ & $\%$ \\
\hline
\end{tabular}




\begin{tabular}{lllllllll}
$0-10$ & 5,75 & 3,33 & 1,39 & 205,88 & 4,61 & 46,87 & 19,17 & 2,61 \\
$10-20$ & 5,80 & 3,35 & 1,43 & 209,25 & 4,44 & 50,26 & 20,25 & 2,58 \\
$20-30$ & 5,82 & 3,25 & 1,39 & 236,00 & 4,44 & 47,46 & 20,49 & - \\
\hline
\end{tabular}

O histórico dos últimos quatro anos de cultivo da área experimental está apresentado na Tabela 6.2.

Tabela 6.2: Descrição do histórico de cultivo da área de estudo sob sistema de plantio direto no período compreendido entre 2011 - 2015.

\begin{tabular}{clc}
\hline & \multicolumn{2}{c}{ Período } \\
\cline { 2 - 3 } Safra & \multicolumn{1}{c}{ Inverno } & Verão \\
\hline $2011 / 2012$ & Soja sob regime hídrico variável & Pousio \\
$2012 / 2013$ & Trigo sob regime hídrico variável & Crotalária \\
$2013 / 2014$ & Amaranto, milheto e quinoa sob regime hídrico variável & Crotalária \\
$2014 / 2015$ & Amaranto, milheto e quinoa sob regime hídrico variável & Milho \\
\hline
\end{tabular}

O experimento apresentou duas fases. A primeira foi iniciada em maio de 2015 com o término em setembro desse mesmo ano. Nessa fase, foram instaladas as plantas de cobertura cultivadas sob regimes hídricos variáveis. Os tratamentos foram dispostos em blocos casualizados, com parcelas subdivididas e quatro repetições. As parcelas foram compostas por quatro regimes hídricos $(167 \mathrm{~mm} ; 268 \mathrm{~mm} ; 381 \mathrm{~mm} ; 432 \mathrm{~mm})$ e as subparcelas foram compostas pelas seguintes plantas de cobertura: amaranto "BRS Alegria" (Amaranthus cruentus), quinoa, "BRS Piabiru" (Chenopodium quinoa, Wild) e milheto (Pennisetum glaucum). As dimensões das parcelas foram de 24 x 3,2 m e as subparcelas foram $8 \times 3,2 \mathrm{~m}$.

A semeadura das três espécies foi realizada manualmente, sem revolvimento sob sistema de plantio direto. A densidade de plantio para as diferentes espécies foi de 200 sementes/m para amaranto, 150 sementes/m para quinoa e 58 sementes/m para milheto. A elevada taxa de semeadura utilizada teve o objetivo de evitar desuniformidade do stand final devido a falhas na germinação ocasionadas pelo pequeno tamanho das sementes. $\mathrm{O}$ excedente foi retirado por desbaste aos 20 dias após a emergência (DAE), obtendo-se um stand de 10 plantas/m para amaranto e 20 plantas/m para quinoa e milheto.

A adubação de base foi feita nos sulcos na dose de $400 \mathrm{~kg} / \mathrm{ha}$ da fórmula 04-3016. Foi realizada adubação nitrogenada de cobertura a lanço, aos 30 dias após a 
emergência das plântulas na dose de 100 kg/há, utilizando-se a ureia. Para evitar a competição das plantas invasoras foram realizadas capinas manuais. $\mathrm{O}$ controle de pragas foi realizado por meio da aplicação de defensivos químicos.

Os diferentes regimes hídricos foram obtidos utilizando-se barra irrigadora de aspersão com 40 m de largura, ligada ao carretel com velocidade regulável. Em cada lateral da barra irrigadora foram instalados oito aspersores uniformemente espaçados e, durante os primeiros 35 dias após a emergência (DAE), a irrigação foi uniforme. Durante esse período foram realizadas doze irrigações totalizando uma lâmina de $135 \mathrm{~mm}$. Após este período foi adaptada a metodologia do line source (HANKS et al., 1976), utilizandose bocais de orifícios decrescentes da área central até o $6^{\circ}$ aspersor e excluindo-se os dois aspersores da extremidade, constituindo quatro regimes hídricos. Para cada lateral da barra irrigadora foram delimitadas 4 parcelas com 3,2 metros de largura e 1 metro de distância entre as parcelas, representando os regimes hídricos. Nessa fase, foram realizadas 13 irrigações e a lâmina acumulada das irrigações uniformes e variáveis foi de $167,268,381,432 \mathrm{~mm}$ para os quatro regimes em estudo. Para determinar o valor da lâmina aplicada foram instaladas, a cada turno de rega, duas fileiras de coletores paralelas à linha de irrigação para medição do volume de água em cada evento de irrigação.

As plantas de cobertura, ao atingirem a fase de florescimento (agosto/2015), foram cortadas com roçadeira, deixadas a superfície para formação de palhada para cobertura do solo, para avaliação dos efeitos no milho em sucessão.

Foram avaliados a produção de matéria seca e os teores de celulose e lignina nas plantas de cobertura. Para verificar a influência das plantas de cobertura no milho foram avaliados os seguintes componentes morfológicos do milho: altura de planta (AP), altura de inserção da espiga (AI) e diâmetro de colmo (DC); e os componentes produtivos: número de fileira de grãos na espiga (NFG), número de grãos por espiga (NGF), peso de mil grãos (PMG), peso médio de espiga (PME), diâmetro de espiga (DE) e a produtividade de grãos (PG).

A avaliação da produção de matéria seca foi realizada colhendo-se uma amostra por parcela na fase de pleno florescimento da cultura, com área de $3 \mathrm{~m}^{2}$ cada, coletandose quatro linhas centrais, com 2,5 m de comprimento. $\mathrm{O}$ material coletado foi levado à estufa a $65^{\circ} \mathrm{C}$, por 72 horas, até atingir peso constante. Os teores de lignina e celulose foram mensurados usando o método sequencial de Van Soest (1991). 
Na etapa seguinte, entre novembro de 2015 a março de 2016, foi implantada a cultura do milho. Foi utilizado o milho híbrido 2B707Hx, plantado espaçamento de 0,75 metros entre linhas (quatro linhas por parcela) e 5 sementes por metro, obtendo-se uma população final de 60.000 plantas/ha. A área útil (local das avaliações) foi composta pelas duas linhas centrais, com 6,0 m de comprimento. A adubação de base consistiu da aplicação de $400 \mathrm{Kg} \mathrm{ha}^{-1}$ da fórmula N-P $\mathrm{O}_{5}-\mathrm{K}_{2} \mathrm{O}$ 04-14-08. Foram aplicados $100 \mathrm{Kg} \mathrm{ha}^{-}$ ${ }^{1}$ de $\mathrm{N}$ em cobertura, sendo realizada em duas fases: $50 \%$ no estádio V4 e 50\% no estádio V6, com sulfato de amônio ( $20 \%$ de N). O controle de plantas daninhas e pragas foi realizado por meio da aplicação de defensivos químicos.

A avaliação da produtividade de grãos do milho foi realizada por meio da colheita manual das espigas das duas linhas centrais, com seis metros lineares e posterior debulha. Após debulhar as espigas, a massa total de grãos foi pesada, tendo-se retirado uma subamostra de peso médio de $300 \mathrm{~g}$. Essa subamostra foi levada para estufa de circulação forçada, a $65^{\circ} \mathrm{C}$, até peso constante, para determinação do teor de umidade dos grãos. Posteriormente, corrigiu-se a produtividade para umidade padrão de 13\%. As mensurações do diâmetro de colmo (do solo a 1,5m de altura), altura de inserção da espiga (do solo a base do pedúnculo da espiga) e a altura de plantas (do solo a base da folha "bandeira") foram realizadas na época do florescimento masculino (emissão de pendão). Essas mensurações foram realizadas em cinco plantas por parcelas. O peso de mil grãos (PMG) foi realizado conforme o método descrito por Brasil (1992), em que se realiza a contagem manual de 100 grãos de cada subparcela e a seguir realiza a pesagem em balança semi-analítica. O resultado é então multiplicado por 10 . O número de grãos por fileira, número de fileiras por espiga, comprimento das espigas foram realizadas por meio da avaliação de cinco espigas por parcela.

A análise estatística foi feita pela análise de variância (ANOVA). O modelo estatístico foi ajustado utilizando-se o procmixed do SAS, por meio do método de máxima verossimilhança restrita (reml). As fontes de variação foram os regimes hídricos $(\mathrm{Rh})$ (parcelas), as plantas de cobertura (Pc) (subparcelas) e suas interações. Para as variáveis em formato de porcentagens (celulose e lignina) foi realizada a transformação "arco seno raiz (x/100)". Estas transformações são necessárias para fins de normalidade dos dados. Para a comparação das médias foi utilizado o teste de Tukey, ao nível de probabilidade de 5\%. Todas as análises foram realizadas pelo software estatístico SAS versão 9.0 


\subsection{RESULTADOS E DISCUSSÃO}

Houve diferença significativa na produção de matéria seca e nos teores de celulose e lignina nas plantas de cobertura (Tabela 6.3). O regime hídrico influenciou a produção de matéria seca e os teores de lignina das plantas de cobertura. Não houve interação entre os fatores.

Tabela 6.3 - Análise de variância (Valores de F) para a produção de matéria seca e teores de lignina e celulose em função da planta de cobertura e do regime hídrico.

\begin{tabular}{cccc}
\hline $\begin{array}{c}\text { Fonte de } \\
\text { variação }\end{array}$ & Matéria seca & Celulose & Lignina \\
\hline Pc & $11,64^{* *}$ & $6,28^{*}$ & $18,89^{* *}$ \\
Rh & $13,65^{* *}$ & 1,62 & $4,86^{* *}$ \\
Pc x Rh & 2,09 & 0,2 & 0,45 \\
\hline Pc = planta de cobertura; $R$ Rh $=$ regime hídrico; $* *, *$ significativos a 0,01 e 0,05 de probabilidade,
\end{tabular}
respectivamente pelo teste $\mathrm{F}$.

O milheto foi a espécie que apresentou o maior teor de celulose e o menor teor de lignina (Tabela 6.4). O amaranto e a quinoa apresentaram valores semelhantes para essas variáveis. Carvalho et al. (2010), ao analisarem os teores de celulose, hemicelulose e lignina em plantas de cobertura, também observaram que o milheto apresentou os menores teores de lignina. Os teores de lignina e celulose são fatores importantes na formação e manutenção de palhada no solo (Espindola et al., 2006; Carvalho et al., 2008; Carvalho et al., 2009; Acosta et al., 2014; Carvalho et al., 2015). A lignina é uma molécula que que tem função de conferir rigidez à parede celular e a sua taxa de decomposição é lenta quando comparada a de celulose e hemicelulose (Carvalho et al., 2010). Maiores teores de lignina representam redução na taxa de decomposição da palhada, enquanto que teores mais baixos desses compostos proporcionam maiores taxas de decomposição, consequentemente, maior ciclagem de nutrientes. Isso significa que a taxa de decomposição do milheto pode ser mais rápida o que significa que os minerais resultantes estarão disponíveis já para o próximo cultivo.

O milheto e o amaranto foram as espécies com maior produção de matéria seca, com produções de 13,33 e 13,26 t ha ${ }^{-1}$, respectivamente. Boer et al., (2008) em trabalho realizado com o milheto ADR500 e Carvalho et al. (2015) com o milheto BR05, ambos na região Centro-Oeste do Brasil, e Borges et al., (2015) na região Noroeste de São Paulo obtiveram produtividades de 10,81 e 4,62 e 7,40 $\mathrm{t} \mathrm{ha}^{-1}$ de biomassa seca, respectivamente. 
Já Costa et al., (2015), estudando o efeito de espaçamento e diferentes épocas de plantio no desempenho de espécies forrageiras na região sudeste, observaram produção de até 17,05 $\mathrm{t} \mathrm{ha}^{-1}$ para o milheto.

Com relação ao amaranto, os valores de biomassa seca obtidos no presente trabalho foram bastante superiores a outros relatados na literatura (Erasmo et al., 2004; Boer et al., 2007; Costa et al., 2008; Ferreira et al., 2014).

Tabela 6.4 - Valores médios da produção de matéria seca e teores de celulose e lignina nas plantas de cobertura avaliadas sob regime hídrico variável.

\begin{tabular}{cccc}
\hline $\begin{array}{c}\text { Planta de } \\
\text { cobertura }\end{array}$ & $\begin{array}{c}\text { Matéria seca } \\
\mathrm{tha}^{-1}\end{array}$ & Celulose $(\%)$ & Lignina (\%) \\
\hline Quinoa & $10,00 \mathrm{~b}$ & $26,75 \mathrm{~b}$ & $4,28 \mathrm{a}$ \\
Milheto & $13,33 \mathrm{a}$ & $30,41 \mathrm{a}$ & $3,64 \mathrm{~b}$ \\
Amaranto & $13,26 \mathrm{a}$ & $27,90 \mathrm{~b}$ & $4,35 \mathrm{a}$ \\
\hline
\end{tabular}

Médias seguidas de letras diferentes, na coluna, diferem estatisticamente entre si, pelo teste de Tukey ao nível de 5\% de probabilidade. Os valores de celulose e lignina foram transformados "arco seno raiz (x/100)"

Observou-se aumento do teor de lignina nas espécies à medida que se aumentou a disponibilidade hídrica até um certo limite, quando houve o decréscimo no teor desse composto (Tabela 6.5). Os teores de celulose não foram influenciados pelos regimes hídricos. A produção de matéria seca das plantas de cobertura foi afetada somente na lâmina inferior de água $(167$ mm) e não houve diferença estatística nos demais regimes. Entretanto esta lâmina inferior normalmente não ocorre na prática na região do Cerrado. Junior Ramos et al., (2013) encontraram reduções de até 39\% na matéria seca do milheto ao reduzir a disponibilidade de água. Cunha et al. (2016), em análise do crescimento e produção da cana de açúcar em função da adubação nitrogenada e lâminas de irrigação, no município de Rio Verde - GO, observaram aumento no tamanho das plantas a medida que se aumentou a disponibilidade hídrica, e consequentemente, maior produção de matéria seca. Segundo Shigaki et al., (2004), a água desempenha um papel fundamental no alongamento dos entrenós, o que resulta em plantas mais altas e com maior produção de matéria seca.

Tabela 6.5 - Valores médios da produção de matéria seca e teores de celulose e lignina na parte aérea de amaranto, milheto e quinoa em função dos regimes hídricos aplicados.

\begin{tabular}{cccc}
\hline $\begin{array}{l}\text { Regime } \\
\text { hídrico }\end{array}$ & $\begin{array}{c}\text { Matéria seca } \\
\mathrm{t} \mathrm{ha}^{-1}\end{array}$ & Celulose (\%) & Lignina (\%) \\
\hline 167 & $9,35 \mathrm{~b}$ & $26,20 \mathrm{a}$ & $3,68 \mathrm{~b}$
\end{tabular}


Médias seguidas de letras diferentes, na coluna, diferem estatisticamente entre si, pelo teste de Tukey ao nível de $5 \%$ de probabilidade. Os valores de celulose e lignina foram transformados "arco seno raiz (x/100)"

Os dados da análise de variância (valores de F) dos componentes morfológicos do milho indicam que os regimes hídricos aplicados nas parcelas, anteriormente ao plantio do milho, promoveram diferenças significativas na altura de plantas e altura de inserção de espiga (Tabela 6.6). Os tratamentos das subparcelas (plantas de cobertura) cultivadas anteriormente ao plantio do milho influenciaram significativamente a altura de plantas, altura de inserção de espiga e o diâmetro de colmo. Resultados semelhantes foram obtidos em trabalhos que avaliaram o efeito de plantas de cobertura sobre características morfológicas do milho em diferentes regiões do país (Favarato et al., 2016; Borges et al., 2015). Entretanto, em alguns trabalhos realizados na região Nordeste e Centro Oeste do Brasil não foi observado o efeito de plantas de cobertura nessas variáveis (Albuquerque et al., 2013; Kappes et al., 2013; Rosa et al., 2011; Carvalho et al; 2004).

Tabela 6.6 - Análise de variância (Valores de F) para os componentes morfológicos do milho.

\begin{tabular}{cccc}
\hline $\begin{array}{c}\text { Causa } \\
\text { variação }\end{array}$ & Altura de plantas & Altura inserção espiga & Diâmetro de colmo \\
\hline $\mathbf{P c}$ & $7,04^{* *}$ & $7,74^{* *}$ & $3,66^{* *}$ \\
$\mathbf{R h}$ & $13,57^{* *}$ & $13,39^{* *}$ & 3,53 \\
$\mathbf{P c} \mathbf{x}$ Rh & 0,73 & 1,33 & 0,4 \\
\hline $\begin{array}{l}\text { Pc }=\text { planta de cobertura; } \mathrm{Rh}=\text { regime hídrico; } \\
\text { respectivamente pelo teste } \mathrm{F} \text {. }\end{array}$
\end{tabular}

As plantas de milho cultivadas sobre a palhada de milheto apresentaram os maiores valores de altura de plantas $(2,96 \mathrm{~m})$ e altura de inserção de espiga $(1,35 \mathrm{~m})$ (Tabela 6.7). Apesar de o milheto ter acumulado menores quantidades de macro e micronutrientes que o amaranto e a quinoa, conforme apresentado no capítulo I, esse fato pode ser justificado pelo menor teor de lignina no milheto. Fato este que favorece a decomposição mais rápida da espécie e maior liberação de nutrientes para o milho. Ferreira et al. (2011) e Paternelli et al. (2011) afirmam que resíduos com elevada 
decomposição proporcionam liberação mais rápida de nutrientes, com destaque para o nitrogênio. Resultados semelhantes foram obtidos por Borges et al., (2015), que observaram maiores valores de altura de plantas $(2,07 \mathrm{~m})$ e altura de inserção de espiga (1,07 m) no milho cultivado após o milheto, no estado de São Paulo. A altura de plantas, segundo Silva et al. (2006) é um parâmetro que expressa o desenvolvimento da cultura e tem correlação positiva com a produtividade. Plantas maiores tendem a ser mais produtivas, provavelmente porque acumulam maiores quantidades de reservas no colmo. Ressalta-se ainda que a altura de planta e de inserção da espiga são variáveis de grande importância por estarem diretamente relacionadas com a tolerância ao acamamento. Segundo Li et al., (2007) e Siqueira et al. (2009), quanto maior for a altura de inserção de espiga, maior será a susceptibilidade da planta ao acamamento.

Quanto ao diâmetro do colmo, os menores valores foram obtidos nas plantas de milho cultivadas sobre a palhada de amaranto.

Tabela 6.7 - Valores médios das características morfológicas do milho em função da planta de cobertura antecessora.

\begin{tabular}{|c|c|c|c|}
\hline \multirow{2}{*}{$\begin{array}{l}\text { Planta de } \\
\text { cobertura }\end{array}$} & Altura de plantas & Altura inserção espiga & Diâmetro de colmo \\
\hline & \multicolumn{2}{|r|}{$\mathrm{M}$} & $\mathrm{mm}$ \\
\hline Quinoa & $2,87 \mathrm{~b}$ & $1,29 \mathrm{~b}$ & $18,94 \mathrm{ab}$ \\
\hline Milheto & $2,96 \mathrm{a}$ & $1,35 \mathrm{a}$ & $19,60 \mathrm{a}$ \\
\hline Amaranto & $2,86 \mathrm{~b}$ & $1,28 \mathrm{~b}$ & $18,75 \mathrm{~b}$ \\
\hline
\end{tabular}

Médias seguidas de letras diferentes, na coluna, diferem estatisticamente entre si, pelo teste de Tukey ao nível de $5 \%$ de probabilidade.

Avaliando-se os efeitos do regime hídrico aplicado às plantas de cobertura antecessoras, observa-se que a menor altura de planta e altura de inserção de espiga ocorreram no menor regime hídrico (Tabela 6.8). Esse resultado pode estar relacionado à quantidade de matéria seca produzida pelas culturas nos diferentes regimes hídricos, uma vez que no menor regime hídrico $(167 \mathrm{~mm})$ foi obtida a menor produção de matéria seca $\left(9,35 \mathrm{t} \mathrm{ha}^{-1}\right)$, contribuindo assim para menor cobertura do solo e menor ciclagem de nutrientes para a cultura subsequente.

Tabela 6.8 - Valores médios das características morfológicas do milho em função do regime hídrico aplicado a planta de cobertura antecessora. 


\begin{tabular}{cccc}
\hline \multirow{2}{*}{$\begin{array}{c}\text { Regime } \\
\text { hídrico }(\mathrm{mm})\end{array}$} & Altura de plantas & Altura inserção espiga & Diâmetro de colmo \\
\cline { 2 - 3 } & & & \\
\hline 167 & $2,75 \mathrm{~b}$ & $\mathrm{~m}$ & $\mathrm{~mm}$ \\
268 & $2,94 \mathrm{a}$ & $1,22 \mathrm{~b}$ & $18,18 \mathrm{a}$ \\
381 & $2,97 \mathrm{a}$ & $1,34 \mathrm{a}$ & $19,18 \mathrm{a}$ \\
432 & $2,92 \mathrm{a}$ & $1,36 \mathrm{a}$ & $19,50 \mathrm{a}$ \\
& & $1,34 \mathrm{a}$ & $19,51 \mathrm{a}$ \\
\hline
\end{tabular}

Médias seguidas de letras diferentes, na coluna, diferem estatisticamente entre si, pelo teste de Tukey ao nível de $5 \%$ de probabilidade.

A produtividade de grãos não foi influenciada pelas plantas de coberturas cultivadas anteriormente sob diferentes regimes hídricos (Tabela 6.9). Esses Resultados corroboram com os de Torres et al., (2015), e Camargo et al. (2007) que não verificaram efeito de plantas de cobertura na produtividade de grãos. Albuquerque et al. (2013) em estudo sobre efeito de plantas de cobertura na produção de milho no estado de Alagoas encontraram diferenças significativas entre plantas de cobertura e produtividade do milho. Carvalho et al., (2015) observaram produtividades de até $12,13 \mathrm{t} \mathrm{ha}^{-1}$ nas parcelas de milho cultivadas após o milheto em Planaltina - DF.

Entre os componentes de produção avaliados, observou-se que apenas o diâmetro de espiga e o número de grãos por fileira foram influenciados pelas plantas de cobertura. Para as demais variáveis não houve diferença estatística.

Tabela 6.9 - Análise de variância (Valores de F) para produtividade de grãos e componentes produtivos do milho.

\begin{tabular}{ccccccc}
\hline $\begin{array}{c}\text { Causa } \\
\text { variaçã }\end{array}$ & $\begin{array}{c}\text { Produtividade } \\
\text { de grãos }\end{array}$ & $\begin{array}{c}\text { Peso } \\
\text { médio } \\
\text { espiga }\end{array}$ & $\begin{array}{c}\text { Diâmetro } \\
\text { espiga }\end{array}$ & $\begin{array}{c}\text { Compriment } \\
\text { o espiga }\end{array}$ & $\begin{array}{c}\mathrm{N}^{\circ} \\
\text { fileira } \\
\text { grãos }\end{array}$ & $\begin{array}{c}\mathrm{N}^{\circ} \text { grãos } \\
\text { fileira }\end{array}$ \\
\cline { 2 - 7 } $\mathrm{Pc}$ & 2,35 & 2,3 & $4,37^{*}$ & 1,69 & 0,79 & $3,2^{*}$ \\
$\mathrm{Rh}$ & 1,97 & 0,57 & 2,23 & 0,95 & 0,3 & 0,32 \\
$\mathrm{Pc} \times \mathrm{Rh}$ & 1,44 & 0,89 & 1,13 & 1,14 & 2,11 & 2,46 \\
\hline
\end{tabular}

$\mathrm{Pc}=$ planta de cobertura; $\mathrm{Rh}=$ regime hídrico; $*$ significativos a 0,05 de probabilidade, respectivamente pelo teste $\mathrm{F}$.

Observa-se que apesar de não haver diferenças significativas entre as plantas de cobertura na produção de grãos, os valores obtidos são considerados altos. A produtividade média nacional na safra $2015 / 16$ foi de 4.799 e $3.904 \mathrm{Kg} \mathrm{ha}^{-1}$ na primeira 
e segunda safra respectivamente (CONAB, 2016). Apesar de não ter ocorrido diferença significativa, nos tratamentos com cultivo anterior de quinoa, a produtividade do milho tendeu a ser $600 \mathrm{~kg} \mathrm{ha}^{-1}$ maior que naquela sob cultivo anterior de amaranto. $\mathrm{O}$ maior diâmetro de espiga foi obtido na área cultivada sobre palhada de milheto e amaranto e a maior quantidade de grãos por fileira foi obtida na área cultivada sobre palhada de milheto e quinoa. Favarato et al. (2016) não encontraram diferença no diâmetro de espiga em função das plantas de cobertura estudadas.

Tabela 6.10 - Valores médios da produtividade de grãos e características produtivas do milho em função das plantas de cobertura antecessoras.

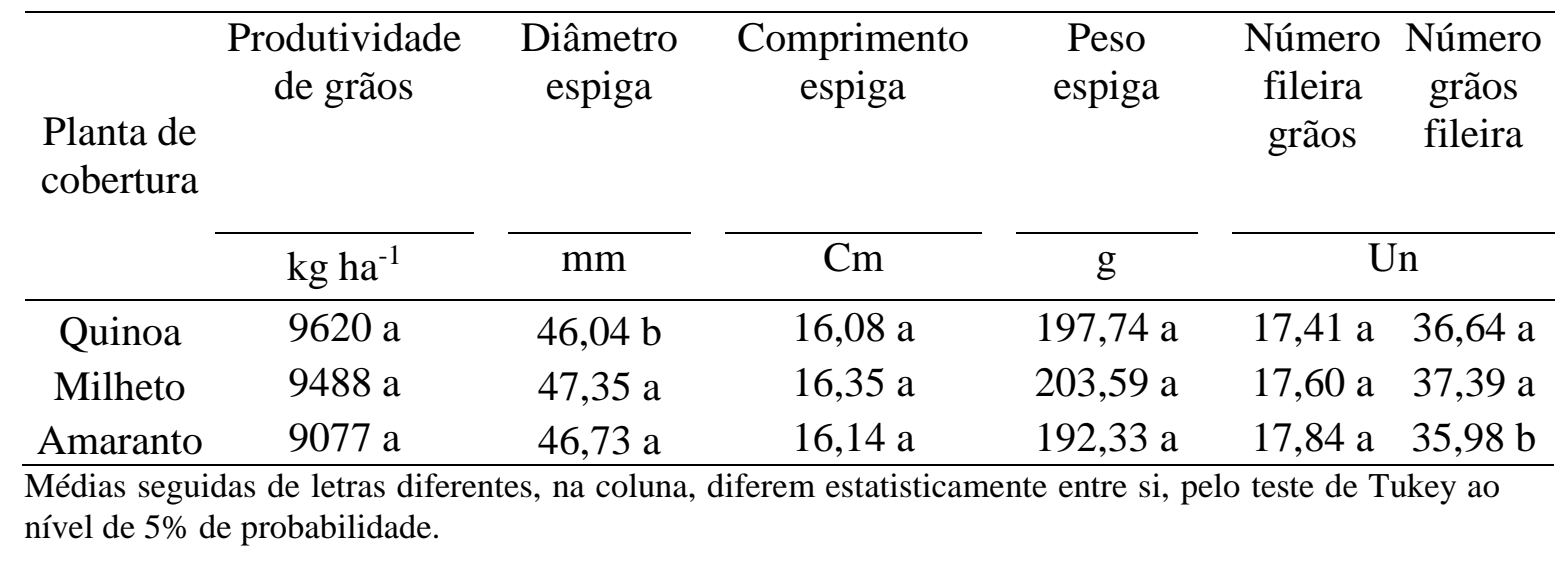

\subsection{CONCLUSÕES}

Os regimes hídricos influenciaram a produção de matéria seca os teores de lignina na parte aérea das plantas de cobertura.

O regime hídrico aplicado as plantas de cobertura, bem como as diferentes espécies de plantas de cobertura, influenciaram os atributos morfológicos (altura de planta, altura de inserção de espiga, diâmetro de colmo), e alguns dos atributos produtivos (número de grãos por fileira e diâmetro de espiga) do milho cultivado em sucessão.

As plantas de cobertura promoveram efeito semelhante na produtividade de milho cultivado em sucessão. 


\subsection{REFERÊNCIAS BIBLIOGRÁFICAS}

ACOSTA, J.A.A; AMADO, T.J.C; SILVA, L.S; SANTI, A; WEBER, M.A. Decomposição da fitomassa de plantas de cobertura e liberação de nitrogênio em função da quantidade de resíduos aportada ao solo sob sistema plantio direto. Ciência Rural, Santa Maria, v. 44, p. 801-809, 2014.

ALBUQUERQUE, A. W., SANTOS, J. R., MOURA FILHO, G. E REIS, L. S. Plantas de cobertura e adubação nitrogenada na produção de milho em sistema de plantio direto. Revista Brasileira de Engenharia Agrícola e Ambiental, 17, 721-726, 2013.

BARROS, D.L; GOMIDE, P.H.L; CARVALHO, G.J. Plantas de cobertura e seu efeito na cultura em sucessão. Biosci. J, Uberlândia, v. 29, n. 2, p. 308-318, 2013.

BOER, C. A; ASSIS, R.L; SILVA, G.P; BRAZ, A.J.B.P; BARROSO, A.L.L; CARGNELLUTI FILHO, A; PIRES, F.R. Biomassa, decomposição e cobertura do solo ocasionada por resíduos culturais de três espécies vegetais na região Centro-Oeste do Brasil. Revista Brasileira de Ciência do Solo, Viçosa, v. 32, n. 2, p. 843-851, 2008.

BORGES, W.L.B; FREITAS, R.S; MATEUS, G.P; SÁ, M.E; ALVES, M.C. Plantas de cobertura para o noroeste do estado de São Paulo. Ciência Rural, Santa Maria, v. 45, n. 5, p. 799-805, 2015.

CARLIN, S. D.; SANTOS, D. M. M. Indicadores fisiológicos da interação entre deficit hídrico e acidez do solo em cana-de-açúcar. Pesquisa Agropecuária Brasileira, v.44, p.1106-1113, 2009.

CARVALHO, M.A.C; SORATTO, R.P; ATHAYDE, L.M.F; ARF, O; SÁ, M.E. Produtividade do milho em sucessão a adubos verdes no sistema de plantio direto e convencional. Pesquisa Agropecuária Brasileira, Brasília, v.39, n.1, p.47-53, 2004.

CARVALHO, A.M; COSER, T.R; REIN, T.A; DANTAS, R.A; SILVA, R.R; SOUZA, K.W. Manejo de plantas de cobertura na floração e na maturação fisiológica e seu efeito na produtividade de milho. Pesquisa Agropecuária Brasileira, v.50, n.7, p.551-561, 2015.

CARDOSO, R.A; BENTO, A.S; MORESKI, H.M; GASPAROTTO, F. Influencia da adubação verde nas propriedades físicas e biológicas do solo e na produtividade da cultura da soja. Semina, Londrina, v. 35, n. 2, p. 51-60, 2014.

CASALI, C.A. Sistemas de culturas sob diferentes manejos em longa duração alteram as formas de fósforo do solo [tese]. Santa Maria: Universidade Federal de Santa Maria; 2012.

COMPANHIA NACIONAL DE ABASTECIMENTO. Perspectivas para a agropecuária, safra 2014-2015. Pesquisa Agropecuária Brasileira, Brasília, v.2, p. 1-155, 2014.

COSTA, N.R; ANDREOTTI, M; ULIAN, N.A; COSTA, B.S; PARIZ, C.M; TEIXEIRA FILHO, M.C.M. Acúmulo de nutrientes e tempo de decomposição da palhada de espécies forrageiras em função de épocas de semeadura. Biosci, J., Uberlândia, v.31, n.3, p. 818829, 2015. 
CUNHA, F.N; SILVA, N.F; SOUZA, A.E.C; TEIXEIRA, M.B; SOARES, F.A.L; VIDAL, V.M. Yield of sugarcane submitted to nitrogen fertilization and water depths by subsurface drip irrigation. Agriambi, v. 20, n. 9, p. 841-846, 2016.

ERASMO, E.A.L; DOMINGOS, V.D; SPEHAR, C.R; DIDONET, J; SARMENTO, R.A; CUNHA, A.M. Avaliação de cultivares de amaranto (Amaranthus spp.) em sistema plantio direto no sul do Tocantins. Biosci. J, Uberlândia, V.20, n. 1, p. 171-176, 2004.

ESPÍNDOLA, J.A.A. et al. Decomposição e liberação de nutrientes acumulados em leguminosas herbáceas perenes consorciadas com bananeira. Revista Brasileira de Ciência do Solo, v.30, p.321- 328, 2006

FERREIRA, C.C; RIBEIRO JUNIOR, W.Q; RAMOS, M.L.G; SPEHAR, C.R; FARIAS, T.R.R. Efeito da densidade de semeadura e doses de nitrogênio sobre a produtividade e biometria de amaranto, no Cerrado do planalto central. Biosci. J, Uberlândia, v. 30, supplement 2, p. 534-546, 2014.

FERREIRA, E. P. B., STONE, L. F., PARTELLI, F. L. E DIDONET, A. D. Produtividade do feijoeiro comum influenciada por plantas de cobertura e sistemas de manejo do solo. Revista Brasileira de Engenharia Agrícola e Ambiental, 15, 695-701, 2011.

KAPPES, C; ARF, O; ANDRADE, J.A.C. Produtividade do milho em condições de diferentes manejos do solo e de doses de nitrogênio. R. Bras. Ci. Solo, v.37, p. 1310 1321, 2013.

LIMA FILHO, O F; AMBROSANO, E.J; ROSSI, F; CARLOS, J.A.D. organizadores. Adubação verde e plantas de cobertura no Brasil: fundamentos e prática. Brasília, DF: Embrapa; 2014. v.1.

LI, Y. et al. The genetics relationships among plant-height traits found using multiple trait QTL mapping of a dent corn and popcorn cross. Genome; Toronto, v.50, n.4, p.357-364, 2007.

MESCHEDE, D. K.; FERREIRA, A. B; RIBEIRO JUNIOR., C. C. Avaliação de diferentes coberturas na supressão de plantas daninhas no Cerrado. Planta Daninha, Viçosa, v. 25, n. 3, p. 465-471, 2007

PACHECO, L. P; LEANDRO, W.M; MACHADO, P.L.O.A; ASSIS, R.L; COBUCCI, T; MADARI, B.E; PETTER, F.A. Produção de fitomassa e acúmulo e liberação de nutrientes por plantas de cobertura na safrinha. Pesquisa Agropecuária Brasileira, Brasília, v. 46, n. 1, p. 17-25, 2011.

PARTELLI, F. L., VIEIRA, H. D., FERREIRA, E. P. B., VIANA, A. P., ESPINDOLA, J. A. A., Urquiaga, S. e Boddey, R. M. Biologic dinitrogen fixation and nutrient cycling in cover crops and their effect on organic Conilon coffee. Semina: Ciências Agrárias, 32, 995-1006, 2011.

SILVA, A. G; CRUSCIOL, C.A.C; SORATTO, R.P; COSTA, C.H.M; FERRARI NETO, J. Produção de fitomassa e acúmulo de nutrientes por plantas de cobertura e cultivo da mamona em sucessão no sistema plantio direto. Ciência Rural, v. 40, n. 10, p. 20922098, 2010. 
Silva, D. A., VITORINO, A. C. T., SOUZA, L. C. F., GONÇALVES, M. C. E ROSCOE, R. Culturas antecessoras e adubação nitrogenada na cultura do milho, em sistema de plantio direto. Revista Brasileira de Milho e Sorgo, 5, 75-88, 2006.

SIQUEIRA, B.C. et al. Ação dos fertilizantes Bacsol e Orgasol na altura de inserção da espiga e coloração dos grãos na cultura do milho orgânico. In: Semana de Ciência e Tecnologia do IFMG. 2., Jornada Científica. 2., 19 a 23 de outubro de 2009.

SPEHAR, C. R. Quinoa: alternativa para a diversificação agrícola e alimentar. Planaltina: Embrapa Cerrados, 2007. 103p.

SPEHAR, C. R. Production systems in the savannas of Brazil: Key factors to sustainability. In: LAL, R. (Ed.). Soil Quality and Agricultural Sustainability. Ann Arbor Press, Chelsea, Michigan. 1998. p. 301-318. 1998

TORRES, J.L.R; CUNHA, M.A; PEREIRA, M.G; VIEIRA, D.M.S. Cultivo de feijão e milho em sucessão a plantas de cobertura. Revista Caatinga, v. 27, n. 4, p. 117-125, 2014.

TORRES, J. L. R. et al. Produtividade de feijão so-bre lâminas de irrigação e Coberturas de solo. Bioscience Journal, Uberlândia, v. 29, n. 4, p. 833-841, 2013.

TEIXEIRA, C. M. et al. Liberação de macronutrien-tes das palhadas de milheto, solteiro e consorciado com feijão-de-porco sob cultivo de feijão. Revista Brasileira de Ciência do Solo, Viçosa, v. 34, n. 2, p. 497-505, 2010. 
CAPITULO III

INFLUÊNCIA DE PLANTAS DE COBERTURA CULTIVADAS SOB REGIMES HÍDRICOS VARIÁVEIS NAS FRAÇÕES DO CARBONO ORGÂNICO DO SOLO. 


\section{INFLUÊNCIA DE PLANTAS DE COBERTURA CULTIVADAS SOB REGIMES HÍDRICOS VARIÁVEIS NAS FRAÇÕES DO CARBONO ORGÂNICO DO SOLO.}

\subsection{RESUMO}

O objetivo desse trabalho foi avaliar as alterações promovidas por plantas de cobertura cultivadas sob regimes hídricos variáveis nas frações do carbono orgânico do solo. O experimento foi desenvolvido em condições de campo, de maio a outubro de 2015, na área experimental da Embrapa Cerrados, localizada no município de Planaltina - DF. Os tratamentos foram dispostos em blocos casualizados, com parcelas subdivididas e três repetições. As parcelas foram compostas por quatro regimes hídricos (167 mm; 268 $\mathrm{mm} ; 381 \mathrm{~mm} ; 432 \mathrm{~mm}$ ) e as subparcelas foram compostas pelas seguintes plantas de cobertura: amaranto "BRS Alegria" (Amaranthus cruentus), quinoa, "Derivado do BRS Piabiru" (Chenopodium quinoa, Wild) e milheto (Pennisetum glaucum). Foram avaliados o carbono orgânico total (COT), carbono das frações húmicas (ácido húmico - $\mathrm{C}-\mathrm{AH}$; ácido fúlvico C-AF e humina C-HUM) e o carbono da biomassa microbiana (C-mic) nas camadas de 0-5, 5-10 e 10-20 cm do solo. O solo cultivado com milheto apresentou os maiores teores de COT e as plantas de cobertura cultivadas em condições de maior disponibilidade hídrica propiciaram aumento nos teores de $\mathrm{C}$ das frações ácido húmico $\mathrm{e}$ ácido fúlvico. $\mathrm{O}$ aumento da disponibilidade hídrica promoveu aumento e reduções no carbono microbiano nas três camadas de solo, dependendo da espécie utilizada.

Palavras-chave: Cobertura do solo; disponibilidade hídrica; substâncias húmicas, carbono microbiano

\subsection{ABSTRACT}

The objective of this work was to evaluate the changes promoted by cover crops cultivated under variable water regimes in the soil organic carbon fractions. The experiment was carried out in field conditions, from May to October, 2015, in the experimental area of Embrapa Cerrados, located in the city of Planaltina - DF. The treatments were arranged in randomized blocks, with subdivided plots and three replicates. The plots were composed of four water regimes $(167 \mathrm{~mm}, 268 \mathrm{~mm}, 381 \mathrm{~mm}$, $432 \mathrm{~mm}$ ) and the subplots were composed of the following cover plants: BRS Alegria (Amaranthus cruentus), quinoa, "Derived from BRS Piabiru" (Chenopodium quinoa, Wild) and millet (Pennisetum glaucum). The total organic carbon (COT), carbon of humic fractions (humic acid - C- AH, fulvic acid C-AF and C-HUM humin) and carbon of microbial biomass (C-mic) $-5,5-10$ and 10-20 cm from the soil were measured. The soil cultivated with millet showed the highest TOC contents and the cover crops grown under conditions of higher water availability resulted in an increase in the $\mathrm{C}$ content of humic acid and fulvic acid fractions. The increase in water availability promoted increase and reductions in microbial carbon in the three soil layers, depending on the species used. 
Keywords: Soil cover; Water availability; Humic substances, microbial carbon

\subsection{INTRODUÇÃ̃O}

O uso de plantas de cobertura contribui para a conservação do solo, reduzindo a erosão e a perda de nutrientes, propicia efeitos positivos nas suas propriedades físicas, químicas e biológicas, bem como pode aumentar o teor de matéria orgânica do solo (Crusciol et al., 2012; Nascente e Crusciol, 2012; Carvalho et al., 2012; Barros et al., 2013; Ensinas et al., 2016). Além de aumentar a matéria orgânica, os resíduos das plantas de cobertura servem de substrato para a biomassa microbiana do solo, principalmente, nas camadas superficiais (Casali, 2012; Guimarães et al., 2013; Lima Filho et al., 2014; Ensinas et al., 2016)

A matéria orgânica do solo desempenha papel importante na manutenção da produtividade dos solos tropicais. Representa o principal reservatório de energia para os microrganismos e nutrientes para as plantas (Perez et al, 2004). É o produto da acumulação de resíduos de plantas e animais parcialmente decompostos e parcialmente ressintetizados e é composta por frações ativas (lábeis) e frações mais estáveis (Passos et al., 2007; Primos et al. 2011; Barreto et al., 2014).

A fração lábil inclui resíduos vegetais em decomposição, formas solúveis em água, macrofauna edáfica e a biomassa microbiana (Campos et al., 2013). A biomassa microbiana é a fração viva da matéria orgânica do solo e é composta por actinomicetos, bactérias, fungos, protozoários e algas. Essa fração atua no processo de decomposição dos resíduos orgânicos e ciclagem de nutrientes (Cardoso et al; Perez et al, 2004) e é fortemente influenciada pelos resíduos vegetais depositados na superfície do solo (Duarte et al., 2014; Loureiro et al., 2016; Coser et al., 2016). Fatores como a composição química (relação $\mathrm{C} / \mathrm{N}$, teores de lignina, celulose e hemicelulose) e a quantidade de resíduo adicionada ao solo influencia o acúmulo de carbono nessa fração (Silva e mendonça, 2007; Zhongkui et al., 2010).

Geralmente, resíduos de decomposição mais lenta proporcionam maior acúmulo da biomassa microbiana por ser fonte de energia e nutrientes aos microrganismos por período mais prolongado (Angers et al., 1993). A maior quantidade de resíduos no solo aumenta a disponibilidade de substrato e determina menor variação térmica e maior disponibilidade de água, favorecendo a biomassa microbiana (Vargas e Scholles, 2000). 
A fração estável (húmica) é composta pelos ácidos fúlvicos, ácidos húmicos e humina (Primo et al., 2011). Essa fração representa cerca de 2/3 do C orgânico, apresenta tempo de permanência no solo que pode chegar a centenas de anos e sua principal função é atuar as propriedades físicas e químicas do solo, além de ser importante no sequestro de C atmosférico (Figueiredo et al., 2010; Silva \& Mendonça, 2007). As frações húmicas da matéria orgânica também são influenciadas pelos resíduos vegetais adicionados ao solo (Guimarães et al., 2013). Dentre elas, a humina é a menos propensa a se alterar com as práticas de manejo porque é a mais estável devido a sua insolubilidade e resistência a biodegradação, favorecida pela formação de complexos argilo-húmicos estáveis (Grinhut et al., 2007).

A quantidade e qualidade dos resíduos vegetais depositados a superfície depende das condições edáficas, práticas sanitárias, manejo e principalmente da disponibilidade hídrica para a planta durante o seu ciclo. A água é um fator essencial para a produção de biomassa e entrada de resíduos orgânicos no solo e sua humificação (Paternelli et al., 2009; Costa et al., 2013) e influencia o acúmulo de matéria orgânica, desde as frações mais lábeis até as mais estáveis (Carmo et al., 2012).

Na região Centro-Oeste do Brasil, a produção e manutenção da cobertura vegetal na superfície do solo é um desafio, devido ao inverno seco, que limita o cultivo nessa época e ao verão quente e chuvoso, que acelera a decomposição da palhada (Leite et al., 2010; Silva et al., 2010). Portanto, deve-se buscar espécies que, simultaneamente, se adaptam a diferentes condições hídricas e promova alterações positivas nos atributos do solo.

Assim, o objetivo desse trabalho foi avaliar as alterações promovidas por plantas de cobertura cultivadas sob regimes hídricos variáveis nas frações do carbono orgânico do solo.

\subsection{MATERIAL E MÉTODOS}

O experimento foi conduzido na estação experimental da Embrapa Cerrados, em Planaltina, DF, Brasil (latitude $15^{\circ} 35^{\prime} 30$ "S, longitude 47 42' 30" W), no período entre maio e outubro de 2015. O clima da região, segundo a classificação de Köppen, é do tipo Cwa (Alvares et al., 2013), com invernos secos e verões chuvosos. A média anual de precipitação é de $1400 \mathrm{~mm}$, e a temperatura média anual de $21,3{ }^{\circ} \mathrm{C}$. Os dados de precipitação pluviométrica e temperaturas máxima e mínima durante a condução do 
experimento são apresentados na Figura 7.1. O solo da área experimental é classificado como Latossolo Vermelho distrófico, textura argilosa (Santos et al., 2013).

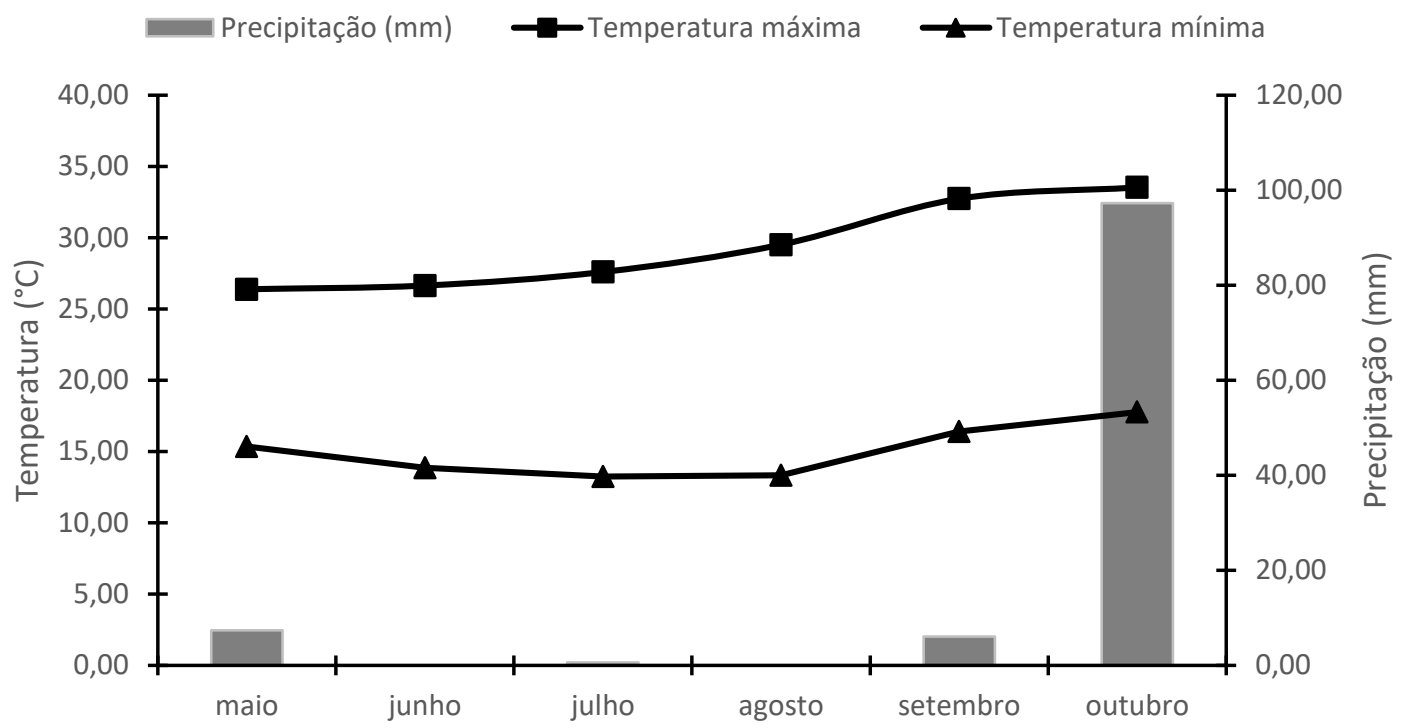

Figura 7.1: Precipitação pluviométrica e temperaturas máximas e mínimas ocorridas na área experimental nos meses de maio a outubro de 2015. *Dados obtidos de estação automática localizada ao lado da área

O histórico dos últimos quatro anos de cultivo da área experimental está apresentado na Tabela 7.2. No momento da implantação do experimento, o solo da camada de 0-10, 10-20 e 20-30 cm apresentava as seguintes características químicas.

Tabela 7.1 - Análise química do solo da área experimental, nas profundidades de 0-10, 10-20, 20-30 cm, realizada em abril/2013.

\begin{tabular}{|c|c|c|c|c|c|c|c|c|}
\hline \multirow{2}{*}{$\begin{array}{l}\text { Profundidade } \\
(\mathrm{cm})\end{array}$} & $\mathrm{pH}$ & $\mathrm{Ca}$ & $\mathrm{Mg}$ & $\mathrm{K}$ & $\mathrm{H}+\mathrm{Al}$ & $\mathrm{P}$ & $S$ & M.O \\
\hline & $\begin{array}{l}\text { em } \\
\text { água }\end{array}$ & $\mathrm{cmoc} / \mathrm{dm}^{3}$ & $\mathrm{cmoc} / \mathrm{dm}^{3}$ & $\mathrm{mg} / \mathrm{dm}^{3}$ & $\mathrm{cmoc} / \mathrm{dm}^{3}$ & $\mathrm{mg} / \mathrm{dm}^{3}$ & $\mathrm{mg} / \mathrm{kg}$ & $\%$ \\
\hline $0-10$ & 5,75 & 3,33 & 1,39 & 205,88 & 4,61 & 46,87 & 19,17 & 2,61 \\
\hline $10-20$ & 5,80 & 3,35 & 1,43 & 209,25 & 4,44 & 50,26 & 20,25 & 2,58 \\
\hline $20-30$ & 5,82 & 3,25 & 1,39 & 236,00 & 4,44 & 47,46 & 20,49 & - \\
\hline
\end{tabular}

Tabela 7.2: Descrição do histórico de cultivo da área de estudo sob sistema de plantio direto no período compreendido entre 2011 - 2015.

\begin{tabular}{ccc}
\hline & \multicolumn{2}{c}{ Período } \\
\cline { 2 - 3 } Safra & Inverno & Verão \\
\hline $2011 / 2012$ & Soja sob regime hídrico variável & Pousio
\end{tabular}


Foi utilizado o delineamento de blocos ao acaso em esquema de parcelas subdivididas, com três repetições. As parcelas foram compostas por quatro regimes hídricos (167 mm; $268 \mathrm{~mm} ; 381 \mathrm{~mm} ; 432 \mathrm{~mm}$ ) e as subparcelas foram compostas pelas seguintes plantas de cobertura: amaranto "BRS Alegria" (Amaranthus cruentus), quinoa, "Genótipo derivado do BRS Piabiru" (Chenopodium quinoa, Wild) e milheto (Pennisetum glaucum). As dimensões das parcelas foram de 24 x 3,2 m e as subparcelas foram $8 \times 3,2 \mathrm{~m}$.

As plantas de cobertura foram semeadas na primeira semana de maio. A semeadura foi realizada manualmente, sob sistema de plantio direto. Foi utilizado o espaçamento de 0,4 m entre linhas e densidade de semeadura de 200 sementes $/ \mathrm{m}$ para amaranto, 150 sementes $/ \mathrm{m}$ para quinoa e 58 sementes $/ \mathrm{m}$ para milheto. A elevada taxa de semeadura utilizada teve o objetivo de evitar desuniformidade do stand final devido a falhas na germinação ocasionadas pelo pequeno tamanho das sementes. $\mathrm{O}$ excedente foi retirado por desbaste aos 20 dias após a emergência (DAE), obtendo-se um stand de 10 plantas $/ \mathrm{m}$ para amaranto e 20 plantas $/ \mathrm{m}$ para quinoa e milheto.

A adubação de base foi feita nos sulcos na dose de $400 \mathrm{~kg} / \mathrm{ha}$ da fórmula 04-3016. Foi realizada adubação nitrogenada de cobertura a lanço, aos 30 dias após a emergência das plântulas na dose de $100 \mathrm{~kg} / \mathrm{ha}$. Para evitar a competição das plantas invasoras foram realizadas capinas manuais. $\mathrm{O}$ controle de pragas foi realizado por meio da aplicação de defensivos químicos. As espécies utilizadas como plantas de cobertura foram cortadas no estágio de florescimento

Os diferentes regimes hídricos foram obtidos utilizando barra irrigadora de aspersão com $40 \mathrm{~m}$ de largura, ligada ao carretel com velocidade regulável. Em cada lateral da barra irrigadora foram instalados oito aspersores uniformemente espaçados. Durante os primeiros 35 dias após a emergência (DAE) a irrigação foi uniforme. Durante esse período foram realizadas dez irrigações totalizando uma lâmina de $135 \mathrm{~mm}$. Após este período foi adaptada a metodologia do line source (HANKS et al., 1976), utilizando bocais de orifícios decrescentes da área central até o $6^{\circ}$ aspersor e excluindo os dois aspersores da extremidade, constituindo quatro regimes hídricos. Para cada lateral da 
barra irrigadora foram delimitadas 4 parcelas com 3,2 metros de largura e 1 metro de distância entre parcelas, representando os regimes hídricos. Nessa fase foram realizadas 13 irrigações e a lâmina acumulada das irrigações uniformes e variáveis foi de 167, 268, 381, $432 \mathrm{~mm}$ para os quatro regimes em estudo. Para determinar o valor da lâmina aplicada foram instaladas, a cada turno de rega, duas fileiras de coletores paralelas à linha de irrigação para medição do volume de água em cada evento de irrigação.

As irrigações foram realizadas conforme descrito no programa de monitoramento de irrigação no Cerrado (EMBRAPA, 2011), utilizando como referência a cultura do trigo, os indicadores agrometeorológicos da região, o tipo de solo e a data de germinação plena.

Em outubro de 2015 realizou-se a coleta de solo para determinação do carbono orgânico total (COT), carbono das frações húmicas (ácido húmico, ácido fúlvico e humina) e carbono da biomassa microbiana (Cmic). Foram coletadas cinco sub amostras por parcela, na camada de 0-5, 5-10 e 10-20 cm. As amostras foram devidamente acondicionadas em sacos plásticos e encaminhadas ao laboratório.

O COT foi determinado por oxidação com dicromato de potássio e titulação com sulfato ferroso amoniacal, segundo o método Walkley e Black (1934).

O fracionamento químico quantitativo do carbono das frações húmicas foi realizado segundo Benites et al. (2003), usando como extrator o $\mathrm{NaOH} \mathrm{0,1} \mathrm{mol} \mathrm{L}{ }^{-1}$. Deste fracionamento foram obtidas as frações: ácidos húmicos $(\mathrm{C}-\mathrm{AH})$, ácidos fúlvicos (C-AF) e humina (C-HUM). Para a separação das substâncias húmicas foram colocados $2 \mathrm{~g}$ de TFSA passados em peneira com malha de $0,5 \mathrm{~mm}$ em tubos de centrífuga de $50 \mathrm{ml}$,

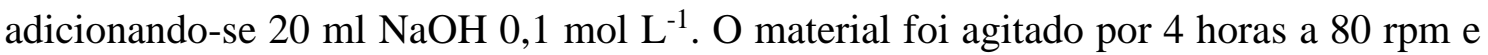
permaneceu em repouso por 12 horas. Posteriormente, a solução foi centrifugada por 30 minutos a $4000 \mathrm{rpm}$. Após isso, o sobrenadante foi recolhido e armazenado em recipiente separado. Foram adicionados novamente $20 \mathrm{ml} \mathrm{NaOH}$ ao material retido nos mesmos tudo da centrífuga. Em seguida foi agitado novamente por 2,5 horas a $80 \mathrm{rpm}$ e posteriormente centrifugado por 30 minutos a $4.000 \mathrm{rpm}$. O sobrenadante foi adicionado ao que estava reservado, formando assim um extrato alcalino no copo descartável contendo as frações $\mathrm{C}-\mathrm{AH}$ e $\mathrm{C}-\mathrm{AF}$. 
A fração humina foi considerada como o precipitado retido nos tubos de centrífuga de $50 \mathrm{~mL}$. Este precipitado foi cuidadosamente transferido para beckers de $50 \mathrm{~mL}$. O pH do extrato alcalino foi ajustado para 1,3-1,5, pela adição de gotas de solução de $\mathrm{H}_{2} \mathrm{SO}_{4}$ $20 \%$. Após o ajuste do $\mathrm{pH}$, o extrato foi centrifugado por 20 minutos a $4.000 \mathrm{~g}$ para separação dos ácidos húmicos e fúlvicos. O sobrenadante, correspondente aos ácidos fúlvicos, foi transferido para outro tubo de centrífuga e seu volume completado para 50 $\mathrm{ml}$ com água destilada. Ao precipitado que corresponde ao $\mathrm{C}-\mathrm{AH}$ foram adicionados 30 $\mathrm{mL}$ de $\mathrm{NaOH} 0,1 \mathrm{~mol} \mathrm{~L}^{-1}$, posteriormente homogeneizado e completado volume com água destilada para $50 \mathrm{~mL}$.

As determinações de carbono nos extratos das frações C-AF, C-AH e C-HUM foram realizadas através da oxidação com dicromato de potássio e titulação do excesso com sulfato ferroso amoniacal de acordo com Yeomans e Bremner (1988).

O carbono da biomassa microbiana do solo (CBM) foi avaliado pelo método da fumigação extração, de acordo com Vance et al. (1987). Por esse método foram retiradas duas alíquotas de $10 \mathrm{~g}$ de solo por amostras. A primeira alíquota foi fumigada em dessecador contendo um Becker com pérolas de vidro e clorofórmio. Após um período de 24 horas procedeu-se a retirada do resíduo de clorofórmio do dessecador. A segunda alíquota serviu de controle (não fumigada). Ambas alíquotas receberam, então, $40 \mathrm{~mL}$ de $\mathrm{K}_{2} \mathrm{SO}_{4}$ e foram agitadas por 30 minutos. A suspensão resultante foi filtrada em papel de filtro Whatman $\mathrm{n}^{\circ} 1$. O carbono orgânico dos extratos foi determinado pela digestão de 10 mL do filtrado com $1 \mathrm{~mL}$ de $\mathrm{K}_{2} \mathrm{Cr}_{2} \mathrm{O}_{7}$ e $10 \mathrm{~mL}$ de uma mistura de $\mathrm{H}_{2} \mathrm{SO}_{4}$ e $\mathrm{H}_{3} \mathrm{PO}_{4}$ (1:1) em erlenmayers de $50 \mathrm{~mL}$. $\mathrm{O}$ excesso de $\mathrm{K}_{2} \mathrm{Cr}_{2} \mathrm{O}_{7}$ foi determinado por titulação com sulfato ferroso de amônio, utilizando-se difenilanina sulfonato de bário como indicador. O C da biomassa foi calculado através da seguinte forma:

$$
\text { C biomassa }=2,64 E C
$$

onde $\mathrm{EC}=(\mathrm{C}$ orgânico extraído de solos fumigados $)-($ C-orgânico de extraído de solos não fumigados).

A análise estatística foi feita pela análise de variância (ANOVA). O modelo estatístico foi ajustado utilizando-se o procmixed do SAS, por meio do método de máxima verossimilhança restrita (reml). As fontes de variação foram os regimes hídricos $(\mathrm{Rh})$ (parcelas), as plantas de cobertura (Pc) (subparcelas) e suas interações. Para a comparação 
das médias foi utilizado o teste de Tukey, ao nível de probabilidade de 5\%. Todas as análises foram realizadas pelo software estatístico SAS versão 9.

\subsection{RESULTADOS E DISCUSSÃO}

Verificou-se diferença significativa $(\mathrm{p}<0,01)$ no carbono orgânico total para plantas de cobertura e regime hídrico, na profundidade de $0-5 \mathrm{~cm}$ (Tabela 7.3). Quanto ao carbono das frações húmicas observou-se que, para o ácido húmico, a interação foi significativa nas profundidades de $0-5$ e $5-10 \mathrm{~cm}$. Na camada $10-20 \mathrm{~cm}$ houve efeito significativo de plantas de cobertura e regime hídrico; para o ácido fúlvico a interação foi significativa nas três profundidades; para a humina a interação foi significativa nas profundidades de 5-10 e 10-20 e na profundidade de 0-5 houve efeito apenas do fator regime hídrico. Com relação ao carbono da biomassa microbiana, observou-se que a interação foi significativa nas três profundidades.

Tabela 7.3: Análise de variância (valores de F) para as variáveis carbono orgânico total, frações húmicas (ácido húmico, ácido fúlvico e humina) e carbono microbiano, em função dos regimes hídricos e das plantas de cobertura.

\begin{tabular}{|c|c|c|c|}
\hline \multirow{2}{*}{$\begin{array}{c}\text { Fontes } \\
\text { de } \\
\text { variação }\end{array}$} & \multicolumn{3}{|c|}{ Profundidade } \\
\hline & $0-5$ & $5-10$ & $10-20$ \\
\hline & \multicolumn{3}{|c|}{ Carbono orgânico total } \\
\hline Pc & $8,54 * *$ & 1,29 & 3,20 \\
\hline $\mathrm{Rh}$ & $19,15^{* *}$ & 4,20 & 0,89 \\
\hline \multirow[t]{2}{*}{ Pc $x \mathrm{Rh}$} & 1,88 & 1,78 & 1,38 \\
\hline & \multicolumn{3}{|c|}{ Ácido húmico } \\
\hline $\mathrm{Pc}$ & $41,44 * *$ & $82,89 * *$ & $12,79 * *$ \\
\hline $\mathrm{Rh}$ & $16,88 * *$ & $14,57 * *$ & $12,81 * *$ \\
\hline \multirow[t]{2}{*}{ Pc $x$ Rh } & $9,48 * *$ & $13,22 * *$ & 2,56 \\
\hline & \multicolumn{3}{|c|}{ Ácido fúlvico } \\
\hline Pc & $9,86^{* *}$ & 0,71 & 0,71 \\
\hline $\mathrm{Rh}$ & 1,75 & $5,35 *$ & $8,37 * *$ \\
\hline $\mathrm{Pc} \times \mathrm{Rh}$ & $6,60 * *$ & $5,67 * *$ & $11,54 * *$ \\
\hline \multicolumn{4}{|c|}{ Humina } \\
\hline $\mathrm{Pc}$ & 0,35 & $20,72 * *$ & $10,43 * *$ \\
\hline $\mathrm{Rh}$ & $7,83 *$ & $6,74 *$ & $7,55^{*}$ \\
\hline
\end{tabular}




\begin{tabular}{cccc} 
Pc x Rh & 1,11 & $7,18 * *$ & $3,52^{*}$ \\
& \multicolumn{3}{c}{} \\
Pc & $10,98^{* *}$ & Carbono microbiano \\
$\mathrm{Rh}$ & 0,45 & 2,21 & $7,94^{* *}$ \\
$\mathrm{Pc} \times \mathrm{Rh}$ & $3,42^{*}$ & 4,60 & 0,57 \\
**** significativo a 1 e $5 \%$ de probabilidade respectivamente pelo teste $\mathrm{F}$. & $18,38^{* *}$ \\
\hline
\end{tabular}

**; * significativo a 1 e $5 \%$ de probabilidade respectivamente pelo teste $\mathrm{F}$.

\section{Carbono orgânico total (COT)}

Na camada de 0-5 cm, os maiores teores de COT foram encontrados no solo cultivado com milheto $\left(28,47 \mathrm{~g} \mathrm{~kg}^{-1}\right)$, que diferiu estatisticamente do amaranto e da quinoa (Tabela 7.4). O sistema radicular das gramíneas favorece o aporte de maior quantidade de resíduos e incrementos no COT (Ensinas et al., 2016). Por apresentarem maior densidade de raízes e melhor distribuição do sistema radicular no solo, há maior liberação de exsudatos e promovem a união de agregados pequenos e formação de agregados maiores, e estes asseguram proteção física e aumento do COT no solo (Santos et al., 2008; Silva et al., 2016). Silva et al., (2016) avaliando o efeito de plantas de cobertura na agregação e proteção física do carbono orgânico do solo, observaram que o milheto e a Brachiaria apresentaram grande capacidade de formação de agregados. Rossi et al. (2012), em estudo sobre as frações lábeis da matéria orgânica em sistema com Brachiaria e sorgo, observaram maior acúmulo nos teores de COT quando comparado com a área de cerrado nativo.

Para as demais profundidades não houve diferença significativa entre as espécies nos teores de COT. Apesar de as profundidades não terem sido comparadas estatisticamente, observa-se tendência de redução no COT em profundidade em todas as espécies estudadas.

Tabela 7.4: Efeito da planta de cobertura nos teores de carbono orgânico total nas profundidades de $0-5 \mathrm{~cm}, 5-10$ e $10-20 \mathrm{~cm}$ em Latossolo cultivado sob sistema de plantio direto.

\begin{tabular}{cccc}
\hline $\begin{array}{c}\text { Planta de } \\
\text { cobertura }\end{array}$ & $0-5$ & Profundidade \\
& & $5-10$ & $10-20$ \\
\hline Amaranto & $25,84 \mathrm{~b}$ & Carbono total $\mathrm{g} \mathrm{kg}^{-1}$ & 17,29 \\
Milheto & $28,47 \mathrm{a}$ & 19,32 & 16,86 \\
Quinoa & $25,81 \mathrm{~b}$ & 19,02 & 16,61 \\
\hline
\end{tabular}

Médias seguidas pelas mesmas letras não diferem entre si pelo teste de Tukey ao nível de 5\%. 
Quanto ao fator regime hídrico, observou-se, para a camada de 0-5 cm, que o menor regime hídrico foi o que promoveu o menor acúmulo de carbono (Tabela 7.5), promovendo diminuição de até $22 \%$ nos teores de COT ao se comparar o menor regime hídrico com os demais. Provavelmente, isto ocorre devido a maior produção de biomassa pelas plantas e consequentemente maior aporte de material orgânico ao solo quando cultivadas em condições de disponibilidade hídrica adequada. Com o maior fornecimento de água, a absorção de nutrientes é favorecida e dessa forma ocorre maior produção de biomassa vegetal, tanto na parte aérea como no sistema radicular, aumentando assim os teores de COT (Loss et al., 2013). Em áreas manejadas com irrigação, tem-se obtido maiores valores de COT, oriundos da maior deposição de resíduos vegetais quando comparado a áreas sem irrigação (Denef et al., 2008). Mesmo com o provável aumento do sistema radicular nos maiores regimes hídricos, este efeito não ocorreu nas maiores profundidades em nenhuma das espécies (Tabela 7.4.).

Tabela 7.5: Efeito do fator regime hídrico nos teores de carbono orgânico total nas profundidades de $0-5 \mathrm{~cm}, 5-10$ e 10-20 cm Latossolo cultivado sob sistema de plantio direto..

\begin{tabular}{cccc}
\hline $\begin{array}{c}\text { Regime } \\
\text { hídrico } \\
(\mathrm{mm})\end{array}$ & $0-5$ & $\begin{array}{c}\text { Profundidade } \\
5-10\end{array}$ & $10-20$ \\
\hline & & $\mathrm{COT}\left(\mathrm{g} \mathrm{kg}^{-1}\right)$ & 17,22 \\
167 & $23,34 \mathrm{~b}$ & 18,74 & 16,79 \\
268 & $27,51 \mathrm{a}$ & 19,15 & 16,38 \\
381 & $27,44 \mathrm{a}$ & 18,52 & 17,02 \\
432 & $28,52 \mathrm{a}$ & 19,69 & \\
\hline
\end{tabular}

Médias seguidas pelas mesmas letras não diferem entre si pelo teste de Tukey ao nível de 5\%.

\section{Carbono das frações húmicas}

Com relação as frações húmicas da matéria orgânica, de maneira geral observouse predomínio da fração humina sobre as frações ácido húmico e ácido fúlvico (Tabelas 7.6, 7.7 e 7.8). Vários estudos também evidenciaram o predomínio do carbono dessa fração sobre as demais (Assis et al., 2006; Rossi et al., 2011; Araújo et al., 2014). Normalmente, os maiores valores dessa fração estão relacionados ao tamanho das moléculas e ao maior grau de estabilidade dessa fração (Rossi et al., 2011). Além do mais, a insolubilidade e a resistência à biodegradação dessa fração favorece a formação de complexos argilo-húmicos estáveis, o que garante maior proteção química (Grinhut et al., 
2007). Já o carbono das frações ácido fúlvico e ácido húmico pode ser mineralizado, polimerizado e translocado para camadas mais profundas, devido à sua menor estabilidade e maior mobilidade, resultando em menores concentrações nas camadas de solo (Fontana et al., 2006; Han et al., 2016).

\section{Ácido húmico}

Em geral, o maior teor de carbono na fração ácido húmico foi observado no solo cultivado com quinoa até a lâmina de $268 \mathrm{~mm}$, nas camadas 0 - 5 e 5-10 cm (Tabela 7.6). Na camada de 0-5 m, analisando-se a influência do regime hídrico dentro de cada espécie, observou-se que o aumento da disponibilidade hídrica aumentou em até $104 \%$ e $62 \%$ os teores de $\mathrm{C}$ nessa fração no solo cultivado com amaranto e quinoa, respectivamente, ao se comparar o menor regime hídrico com o maior. Na camada de 5-10 cm, para o amaranto, apesar de não ter havido diferença estatística significativa, também se verificou tendência de aumento da fração ácido húmico. No solo cultivado com quinoa, o teor de C-AH foi menor no menor regime hídrico $(167 \mathrm{~mm})$ e maior no regime hídrico $381 \mathrm{~mm}$. Nos demais regimes hídricos não houve diferença significativa. Porém, também foi observado aumento de até $66 \%$ no C-AH ao se comparar o menor regime hídrico com os demais. No solo cultivado com milheto, os maiores valores de C-AH foram observados nas lâminas 268 e $381 \mathrm{~mm}$, nas profundidades de 0-5 e 5-10 cm. Ao se comparar as espécies, observou-se que na camada de $5-10 \mathrm{~cm}$, a maior disponibilidade hídrica (381 e $432 \mathrm{~mm}$ ) proporcionou maiores teores de $\mathrm{C}-\mathrm{AH}$ no solo cultivado com quinoa, quando comparado com as outras duas espécies. Independente do regime hídrico, observou-se de maneira geral, maiores valores de $\mathrm{C}-\mathrm{AH}$ no solo cultivado com quinoa, nas duas profundidades e tendência de redução nos teores de carbono nessa fração em profundidade.

Segundo Souza e Melo et al., (2003) maiores valores de C-AH, na maioria das vezes implicam em maior expressão da fração coloidal da matéria orgânica, contribuindo assim para maior retenção de umidade, maior agregação do solo e maior retenção de cátions. Araújo et al. (2014) em estudo sobre as frações da matéria orgânica do solo em cafeeiro sob diferentes regimes hídricos na região Centro Oeste, observaram aumento dos teores de $\mathrm{C}-\mathrm{AH}$ com a irrigação. Com relação à tendência de redução dos teores de $\mathrm{C}-$ AH em profundidade, Santos et al., (2013) também observaram que os níveis de C dessa fração diminuíram em profundidade devido à redução dos resíduos vegetais da cultura. 
Tabela 7.6: Desdobramento da interação entre regime hídrico e plantas de cobertura referente aos teores de ácido húmico $\left(\mathrm{g} \mathrm{kg}^{-1}\right)$ nas profundidades de $0-5$ e $5-10 \mathrm{~cm}$ Latossolo cultivado sob sistema de plantio direto..

\begin{tabular}{cccc}
\hline $\begin{array}{c}\text { Regime } \\
\text { hídrico } \\
(\mathrm{mm})\end{array}$ & Amaranto & Milheto & Quinoa \\
\cline { 2 - 4 } & & $0-5$ & \\
167 & $2,05 \mathrm{Bc}$ & $3,20 \mathrm{Ab}$ & $2,89 \mathrm{Ab}$ \\
268 & $2,87 \mathrm{Bbc}$ & $4,46 \mathrm{Aa}$ & $4,42 \mathrm{Aa}$ \\
381 & $3,08 \mathrm{Bb}$ & $3,41 \mathrm{Bb}$ & $4,79 \mathrm{Aa}$ \\
432 & $4,19 \mathrm{Aa}$ & $3,69 \mathrm{Bab}$ & $4,68 \mathrm{Aa}$ \\
& & $5-10$ & $2,73 \mathrm{Ac}$ \\
167 & $2,30 \mathrm{Aa}$ & $2,58 \mathrm{Ab}$ & $4,02 \mathrm{Ab}$ \\
268 & $2,61 \mathrm{Ba}$ & $3,76 \mathrm{Aa}$ & $4,79 \mathrm{Aa}$ \\
381 & $2,75 \mathrm{Ba}$ & $2,60 \mathrm{Bb}$ & $3,99 \mathrm{Ab}$ \\
432 & $2,76 \mathrm{Ba}$ & $3,19 \mathrm{Bab}$ & \\
\hline
\end{tabular}

Médias seguidas pelas mesmas letras, maiúsculas nas linhas e minúsculas nas colunas, não diferem entre si pelo teste de Tukey ao nível de $5 \%$.

Analisando-se o efeito isolado dos fatores regimes hídricos e plantas de cobertura na camada de 10-20 cm, observou-se que o solo cultivado com quinoa apresentou os maiores teores de carbono nessa fração (Tabela 7.7). Quando ao regime hídrico, ocorreu comportamento semelhantes as demais profundidades, ou seja, o aumento da disponibilidade hídrica promoveu aumento o $\mathrm{C}-\mathrm{AH}$.

Tabela 7.7: Efeito do regime hídrico e da planta de cobertura nos teores de ácido húmico $\left(\mathrm{g} \mathrm{kg}^{-1}\right)$ na profundidade de $10-20 \mathrm{~cm}$ em Latossolo cultivado sob sistema de plantio direto.

\begin{tabular}{cccc}
\hline & Planta de cobertura & \\
Amaranto & Milheto & Quinoa & \\
$2,24 \mathrm{~b}$ & $2,63 \mathrm{~b}$ & $3,16 \mathrm{a}$ \\
& & & \\
& Regime hídrico $(\mathbf{m m})$ & & $\mathbf{3 8 1}$ \\
$\mathbf{1 6 7}$ & $\mathbf{2 6 8}$ & $\mathbf{4 3 2}$ \\
$2,14 \mathrm{~b}$ & $2,67 \mathrm{ab}$ & $2,79 \mathrm{a}$ & $3,10 \mathrm{a}$ \\
\hline
\end{tabular}

Médias seguidas pelas mesmas letras minúsculas nas linhas, não diferem entre si pelo teste de Tukey ao nível de $5 \%$.

Foi obtida a relação percentual entre C-AH e COT. A interação foi significativa para as três profundidades e o desdobramento está apresentado na tabela 7.8. Os percentuais de C-AH em relação ao carbono orgânico total variaram de 9,49 - 17,39\%; $11,79-20,67 \%$ e $10,79-25,67 \%$ para as camadas de 0-5, 5-10 e 10-20 respectivamente. Santos et al., (2014) ao avaliarem efeitos de plantas de cobertura em frações da matéria 
orgânica encontraram percentuais de C-AH no COT que variaram de 15-18\% na camada de $0-10 \mathrm{~cm}$ e $14-18 \%$ na camada de $10-20 \mathrm{~cm}$. Barreto et al., (2008) em estudo sobre frações do carbono orgânico total em um solo de mata submetido a diferentes usos encontraram percentuais de C-AH que variaram 4,84 a 9,04\% na profundidade de $0-10 \mathrm{~cm}$ e 4,7 a 5,33\% na profundidade de $10-20 \mathrm{~cm}$. De maneira geral, observou-se maior contribuição dessa fração com o aumento da profundidade. Tal fato justifica-se porque as frações lábeis, fortemente influenciadas pelos resíduos vegetais das camadas superficiais, reduzirem em profundidade, aumentando assim a participação das frações estáveis no carbono orgânico total. $\mathrm{O}$ aumento da disponibilidade hídrica aumentou o percentual do C-AH no COT em $6,04 \%$ e $13,65 \%$ nos solos cultivados com amaranto e quinoa, respectivamente, na profundidade de 0-5 cm; na profundidade de 5-10 e 10-20 cm o aumento do C-AH foi de 2,95 e 6,47\% no solo cultivado com amaranto e 5,07 e 11,43\% nos solos cultivados com quinoa. De maneira geral, os solos cultivados com quinoa apresentaram os maiores percentuais de C-AH no COT, nas três profundidades estudadas e regimes hídricos.

Tabela 7.8: Desdobramento da interação da relação percentual (\%) entre carbono da fração ácido húmico e carbono orgânico total em função da planta de cobertura e do regime hídrico, nas profundidades de 0-5, 5-10 e 10-20 cm.

\begin{tabular}{cccc}
\hline $\begin{array}{c}\text { Regime } \\
\text { hídrico }\end{array}$ & Amaranto & Mlanta de cobertura \\
\hline & & Milheto & Quinoa \\
\hline $\mathbf{1 6 7}$ & $9,49 \mathrm{Bb}$ & $11,81 \mathrm{Ab}$ & $13,65 \mathrm{Ab}$ \\
$\mathbf{2 6 8}$ & $10,30 \mathrm{Bb}$ & $15,48 \mathrm{Aa}$ & $17,08 \mathrm{Aa}$ \\
$\mathbf{3 8 1}$ & $11,48 \mathrm{Bb}$ & $12,18 \mathrm{Bb}$ & $17,39 \mathrm{Aa}$ \\
$\mathbf{4 3 2}$ & $15,53 \mathrm{Aa}$ & $12,50 \mathrm{Bb}$ & $16,42 \mathrm{Aa}$ \\
& & $5-10 \mathrm{~cm}$ & $15,66 \mathrm{Ab}$ \\
$\mathbf{1 6 7}$ & $11,79 \mathrm{Ba}$ & $13,41 \mathrm{Ab}$ & $20,73 \mathrm{Aa}$ \\
$\mathbf{2 6 8}$ & $13,55 \mathrm{Ba}$ & $19,62 \mathrm{Aa}$ & $17,39 \mathrm{Ab}$ \\
$\mathbf{3 8 1}$ & $14,74 \mathrm{Ba}$ & $14,67 \mathrm{Bb}$ & $20,67 \mathrm{Aa}$ \\
$\mathbf{4 3 2}$ & $13,89 \mathrm{Ba}$ & $16,14 \mathrm{Bb}$ & $14,24 \mathrm{Ac}$ \\
& & $10-20 \mathrm{~cm}$ & $18,11 \mathrm{Abc}$ \\
$\mathbf{1 6 7}$ & $10,79 \mathrm{Ab}$ & $12,69 \mathrm{Aa}$ & $25,67 \mathrm{Aa}$ \\
$\mathbf{2 6 8}$ & $11,98 \mathrm{Bab}$ & $17,97 \mathrm{Aa}$ & $21,70 \mathrm{Aab}$ \\
$\mathbf{3 8 1}$ & $12,10 \mathrm{Bab}$ & $16,11 \mathrm{Ba}$ & $15,50 \mathrm{Ba}$ \\
$\mathbf{4 3 2}$ & $17,26 \mathrm{Aba}$ & &
\end{tabular}

Médias seguidas pelas mesmas letras, maiúsculas nas linhas e minúsculas nas colunas, não diferem entre si pelo teste de Tukey ao nível de 5\%. 


\section{Ácido fúlvico}

Analisando-se a camada de 0-5 cm observou-se que os maiores teores de ácido fúlvico, em geral, ocorreram na quinoa, principalmente nas maiores lâminas de água aplicadas. Rosa et al., (2017) estudando as substâncias húmicas em solo cultivado com plantas de cobertura, também observaram diferenças no teor de $\mathrm{C}-\mathrm{AF}$ entre as plantas de cobertura (Mucuna deeringiana, Cajanus cajan, Crotalaria juncea).

$\mathrm{O}$ regime hídrico não influenciou os teores de $\mathrm{C}$ dessa fração no solo cultivado com amaranto. Na quinoa, de maneira geral, o aumento do regime hídrico foi semelhante entre todas as lâminas, com exceção daquela de $167 \mathrm{~mm}$, que promoveu diminuição do C-AF, comparada à lâmina de $381 \mathrm{~mm}$. Araújo et al., (2014) em estudo sobre as frações da matéria orgânica do solo em cafeeiro sob diferentes regimes hídricos na região Centro Oeste, também observaram aumento no teor dessa fração, com o aumento da disponibilidade hídrica. Matei et al. (2012) observaram que a disponibilidade de água no solo favorece o aumento da quantidade e qualidade do C - AF nas camadas superficiais. No milheto, em geral, o C-AF foi semelhante entre as lâminas de água, com exceção da lâmina $268 \mathrm{~mm}$ que apresentou maior C-AF que a de $381 \mathrm{~mm}$.

Já para a camada de 5-10 cm, o regime hídrico influenciou o $\mathrm{C}-\mathrm{AF}$ no solo cultivado com amaranto, sendo o menor teor observado no regime hídrico inferior. Não houve efeito do regime hídrico no $\mathrm{C}-\mathrm{AF}$ no solo cultivado com quinoa. No milheto o menor valor foi obtido novamente no regime $381 \mathrm{~mm}$, em relação à lâmina $268 \mathrm{~mm}$. Na profundidade de 10-20 cm, o regime hídrico também influenciou o $\mathrm{C}-\mathrm{AF}$ no solo cultivado com amaranto. $\mathrm{O}$ fato que se destaca é que o maior teor foi obtido no maior regime hídrico, o que evidencia que elevada disponibilidade de água para o amaranto pode influenciar o $\mathrm{C}$ - AF em camadas mais profundas do solo. Uma possível justificativa está relacionada à maior solubilidade e polaridade dessa fração ocasionada pelo menor peso molecular e maior densidade de grupamentos carboxílicos o que a torna mais móvel no solo, atingindo camadas mais profundas (Silva e Mendonça, 2007). Já para o milheto, os dois regimes hídricos superiores $(381$ e $432 \mathrm{~mm}$ ) reduziram os teores dessa fração. Para a quinoa, o regime hídrico de $432 \mathrm{~mm}$ apresentou menores valores de C-AF que aquele de $268 \mathrm{~mm}$.

Tabela 7.9: Desdobramento da interação entre regime hídrico e plantas de cobertura referente aos teores de ácido fúlvico $\left(\mathrm{g} \mathrm{kg}^{-1}\right)$ nas profundidades de $0-5$ e $5-10$ e 10 $20 \mathrm{~cm}$ em Latossolo cultivado sob sistema de plantio direto. 


\begin{tabular}{cccc}
\hline $\begin{array}{c}\text { Regime } \\
\text { hídrico } \\
(\mathrm{mm})\end{array}$ & Amaranto & Milheto & Quinoa \\
\cline { 2 - 4 } & & $0-5$ & \\
167 & $2,89 \mathrm{Ba}$ & $3,63 \mathrm{Aab}$ & $3,26 \mathrm{Bb}$ \\
268 & $3,44 \mathrm{Aa}$ & $3,86 \mathrm{Aa}$ & $3,91 \mathrm{Aab}$ \\
381 & $3,28 \mathrm{Ba}$ & $3,07 \mathrm{Bb}$ & $4,21 \mathrm{Aa}$ \\
432 & $3,48 \mathrm{Aa}$ & $3,3 \mathrm{Aab}$ & $3,47 \mathrm{Aab}$ \\
& & $5-10$ & \\
167 & $2,36 \mathrm{Bb}$ & $3,1 \mathrm{Aab}$ & $3,19 \mathrm{Aa}$ \\
268 & $3,17 \mathrm{Aa}$ & $3,38 \mathrm{Aa}$ & $3,11 \mathrm{Aa}$ \\
381 & $2,94 \mathrm{Aba}$ & $2,57 \mathrm{Bb}$ & $3,18 \mathrm{Aa}$ \\
432 & $3,29 \mathrm{Aa}$ & $2,90 \mathrm{Aab}$ & $2,78 \mathrm{Aa}$ \\
& & $10-20$ & $2,86 \mathrm{Bab}$ \\
167 & $2,27 \mathrm{Cb}$ & $3,41 \mathrm{Aa}$ & $2,88 \mathrm{Aa}$ \\
268 & $2,65 \mathrm{Ba}$ & $3,05 \mathrm{Aa}$ & $2,70 \mathrm{Aab}$ \\
381 & $2,44 \mathrm{Ba}$ & $2,32 \mathrm{Ab}$ & $2,37 \mathrm{Bb}$ \\
432 & $3,21 \mathrm{Aa}$ & $2,25 \mathrm{Bb}$ & \multicolumn{3}{c}{ Pa cobertura } \\
\hline
\end{tabular}

Médias seguidas pelas mesmas letras, maiúsculas nas linhas e minúsculas nas colunas, não diferem entre si pelo teste de Tukey ao nível de 5\%.

Os percentuais de C-AF no COT nas profundidades de 0-5, 5-10 e 10-20 estão apresentados nas tabelas 7.10 e 7.11. A interação foi significativa para as camadas de 510 e $10-20 \mathrm{~cm}$ e na camada de $0-5 \mathrm{~cm}$ foi significativo apenas para plantas de cobertura. $\mathrm{Na}$ camada de 0-5 cm, o solo cultivado com quinoa apresentou os maiores percentuais. Os percentuais de C-AF variaram de 12,12 a 18,30\% e 12,86 a 19,24\% nas profundidades de 5-10 e 10-20 cm (Tabela 7.11) no solo sob as diferentes plantas de cobertura. Santos et al., (2014) ao avaliarem efeitos de plantas de cobertura em frações da matéria orgânica encontraram percentuais de C-AF no COT que variaram de $14-17 \%$ na camada de $0-10$ cm e $14-16 \%$ na camada de $10-20 \mathrm{~cm}$. Barreto et al., (2008) encontraram percentuais de C-AF que variaram 14,98 a $26,21 \%$ na profundidade de $0-10 \mathrm{~cm}$ e 27,34 a $36,97 \%$ na profundidade de 10-20 $\mathrm{cm}$. O aumento da disponibilidade hídrica aumentou a participação do C-AF no COT em até 4,44\% e 5,92\% no solo cultivado com amaranto, nas profundidades de 5-10 e 10-20 cm, respectivamente. No solo cultivado com quinoa houve reduções de até 6,76 e 3,71\% para essas mesmas profundidades. No milheto também foram observadas reduções de até 1,64 e 6,34\% nas duas profundidades. Ao analisar o efeito isolado do fator planta de cobertura na camada de 0-5 cm, observa-se que o maior percentual de C-AF no COT foi observado no solo cultivado com quinoa. 
Mesmo não tendo sido realizada comparação entre as frações C-AF e C-AH, de maneira geral, observa-se que os percentuais de C-AH no COT foram maiores que os de C-AF. A presença de maiores percentuais da fração C-AH indica um estado mais avançado de mineralização da matéria orgânica (Barreto et al., 2008). Maiores teores de C-AH também são favoráveis à qualidade física do solo, tendo em vista que essa fração húmica é responsável pela maior capacidade de troca catiônica de origem orgânica nas camadas superficiais do solo (Benites et al., 2003).

Tabela 7.10: Relação percentual (\%) entre carbono da fração ácido fúlvico e carbono orgânico total em função da planta de cobertura, nas profundidades de 0-5 em Latossolo cultivado sob sistema de plantio direto.

\begin{tabular}{ccc}
\hline & Planta de cobertura & \\
Amaranto & Milheto & Quinoa \\
$12,72 \mathrm{~b}$ & $12,23 \mathrm{~b}$ & $14,52 \mathrm{a}$ \\
\hline
\end{tabular}

Médias seguidas pelas mesmas letras, minúsculas nas colunas, não diferem entre si pelo teste de Tukey ao nível de $5 \%$.

Tabela 7.11: Desdobramento da interação da relação percentual (\%) entre carbono da fração ácido fúlvico e carbono orgânico total em função da planta de cobertura e do regime hídrico, nas profundidades de 5-10 e 10-20 cm.

\begin{tabular}{cccc}
\hline $\begin{array}{c}\text { Regime } \\
\text { hídrico }\end{array}$ & \multicolumn{3}{c}{ Planta de cobertura } \\
\cline { 2 - 4 } & Amaranto & Milheto & Quinoa \\
\hline $\mathbf{1 6 7}$ & $12,12 \mathrm{Cb}$ & $16,10 \mathrm{~cm}$ & $18,30 \mathrm{Aa}$ \\
$\mathbf{2 6 8}$ & $16,51 \mathrm{Aa}$ & $17,55 \mathrm{Aa}$ & $16,06 \mathrm{Ab}$ \\
$\mathbf{3 8 1}$ & $15,75 \mathrm{Aa}$ & $14,46 \mathrm{Ab}$ & $11,54 \mathrm{Bc}$ \\
$\mathbf{4 3 2}$ & $16,56 \mathrm{Aa}$ & $14,67 \mathrm{Bb}$ & $14,34 \mathrm{Bb}$ \\
& & $10-20 \mathrm{~cm}$ & $17,77 \mathrm{Aa}$ \\
$\mathbf{1 6 7}$ & $12,86 \mathrm{Bb}$ & $19,24 \mathrm{Aa}$ & $17,76 \mathrm{Aa}$ \\
$\mathbf{2 6 8}$ & $15,30 \mathrm{Ab}$ & $18,17 \mathrm{Aa}$ & $18,23 \mathrm{Aa}$ \\
$\mathbf{3 8 1}$ & $14,36 \mathrm{Bb}$ & $14,80 \mathrm{Bb}$ & $14,06 \mathrm{Bb}$ \\
\hline $\mathbf{4 3 2}$ & $18,78 \mathrm{Aa}$ & $12,91 \mathrm{Bb}$ & $\mathrm{c}$ \\
\hline
\end{tabular}

Médias seguidas pelas mesmas letras, maiúsculas nas linhas e minúsculas nas colunas, não diferem entre si pelo teste de Tukey ao nível de 5\%.

\section{Humina}

O regime hídrico influenciou os teores de C $-\mathrm{HUM}$ na profundidade de $0-5 \mathrm{~cm}$ (Tabela 7.12), mas foi semelhante entre as plantas de cobertura (Tabela 7.3). Ao se comparar o menor regime hídrico com o maior observou-se aumento de $12 \%$ no carbono dessa fração, indicando que maiores lâminas de água no solo promovem aumento de 
frações insolúveis de carbono nesta camada de solo, o que pode contribuir para o aumento dos teores de carbono orgânico. Araújo et al. (2014) em estudo sobre as frações da matéria orgânica do solo em cafeeiro sob diferentes regimes hídricos na região Centro Oeste, observaram aumento dos teores de C $-\mathrm{HUM}$ na camada de $0-5 \mathrm{~cm}$ sob irrigação. Uma possível justificativa é que a disponibilidade hídrica na camada superficial favorece o crescimento e a diversidade da população microbiana que tem um papel importante na mineralização e humificação da matéria orgânica (Matei et al 2012; Figueiredo et al., 2012).

Tabela 7.12: Efeito isolado do fator regime hídrico nos teores de humina $\left(\mathrm{g} \mathrm{kg}^{-1}\right)$ na profundidade de $0-5 \mathrm{~cm}$

\begin{tabular}{cccc}
\hline & \multicolumn{4}{c}{ Regime hídrico $(\mathbf{m m})$} & \\
$\mathbf{1 6 7}$ & $\mathbf{2 6 8}$ & $\mathbf{3 8 1}$ & $\mathbf{4 3 2}$ \\
$10,91 \mathrm{~b}$ & $12,48 \mathrm{a}$ & $12,41 \mathrm{a}$ & $12,45 \mathrm{a}$ \\
\hline
\end{tabular}

Médias seguidas pelas mesmas letras minúsculas nas linhas, não diferem entre si pelo teste de Tukey ao nível de $5 \%$.

Analisando-se o desdobramento da interação entre os regimes hídricos e as plantas de cobertura observou-se que o maior teor de C-HUM, na profundidade de 5-10 cm, foi obtido na quinoa, no regime de $381 \mathrm{~mm}$ (Tabela 7.13). O regime hídrico não influenciou no C-HUM no solo cultivado com amaranto e milheto nessa camada de solo. Comparando-se as plantas de cobertura, observa-se que não se diferenciaram quanto ao acúmulo de C-HUM nos regimes de 268 e $432 \mathrm{~mm}$. No regime de $381 \mathrm{~mm}$, a quinoa acumulou maior quantidade de humina e no regime inferior $(167 \mathrm{~mm})$, o milheto apresentou a menor capacidade de acumular carbono nessa fração. Existem poucos trabalhos comparando os regimes hídricos e o fracionamento químico do carbono orgânico no solo, mas há trabalhos como o de Souza et al. (2016) que mostram o efeito de diferentes sistemas de manejo nas frações da matéria orgânica do solo na região Centro Oeste os autores observaram diferenças nos teores de C-HUM, nos sistemas estudados. Já para a camada de 10-20 cm não foi observada a influência do regime hídrico em nenhuma das espécies estudadas. Comparando-se as espécies dentro de cada regime hídrico, observou-se que o amaranto apresentou maior capacidade de acumular carbono nessa fração nos regimes de 268 e 381 mm. Nos demais regimes hídricos, não houve diferença entre as espécies. 
Tabela 7.13: Desdobramento da interação entre regime hídrico e plantas de cobertura referente aos teores de humina $\left(\mathrm{g} \mathrm{kg}^{-1}\right)$ nas profundidades de $5-10$ e $10-20 \mathrm{~cm}$.

\begin{tabular}{cccc}
\hline $\begin{array}{c}\text { Regime } \\
\text { hídrico } \\
(\mathrm{mm})\end{array}$ & Amaranto & Milheto & Quinoa \\
\cline { 2 - 4 } & & $5-10$ & \\
167 & $9,20 \mathrm{Aa}$ & $8,08 \mathrm{Ba}$ & $9,61 \mathrm{Ab}$ \\
268 & $8,57 \mathrm{Aa}$ & $7,95 \mathrm{Aa}$ & $8,51 \mathrm{Ab}$ \\
381 & $8,16 \mathrm{Ba}$ & $8,14 \mathrm{Ba}$ & $12,27 \mathrm{Aa}$ \\
432 & $8,16 \mathrm{Aa}$ & $8,12 \mathrm{Aa}$ & $8,81 \mathrm{Ab}$ \\
& & & \\
& & $10-20$ & $7,09 \mathrm{Aa}$ \\
167 & $7,5 \mathrm{Aa}$ & $7,10 \mathrm{Aa}$ & $7,23 \mathrm{Aba}$ \\
268 & $7,66 \mathrm{Aa}$ & $7,06 \mathrm{Ba}$ & $7,53 \mathrm{Ba}$ \\
381 & $8,10 \mathrm{Aa}$ & $7,37 \mathrm{Ba}$ & $7,36 \mathrm{Aa}$ \\
432 & $7,36 \mathrm{Aa}$ & $7,40 \mathrm{Aa}$ &
\end{tabular}

Médias seguidas pelas mesmas letras, maiúsculas nas linhas e minúsculas nas colunas, não diferem entre si pelo teste de Tukey ao nível de 5\%.

Os percentuais de C-HUM no COT estão apresentados nas Tabelas 7.14 e 7.15. A interação foi significativa para a profundidade de $0-5 \mathrm{~cm}$ (Tabela 7.14). Nas camadas de 5-10 cm e 10-20 cm houve diferença significativa para plantas de cobertura e regime hídrico. (Tabela 7.15). A humina foi a fração que apresentou maior teor em relação ao carbono orgânico total. Resultados semelhantes foram obtidos por Melo et al., (2016) ao estudarem o estoque e frações da matéria orgânica na região Centro Oeste. Maiores percentuais de humina em relação às demais frações indicam que a matéria orgânica do solo está em processo avançado de humificação e favorecem maior expressão da fração coloidal da matéria orgânica (Loss et al., 2010; Guareshi et al., 2013). Os percentuais de C-HUM no COT variaram de 38,20 - 56,48\% na profundidade de 0-5 cm. Santos et al., (2014) ao avaliarem os efeitos de plantas de cobertura em frações da matéria orgânica encontraram percentuais de C-AH no COT que variaram de 30-35\% na camada de 0-10 cm. Souza e Melo (2003) encontraram 50-78\%; Leite et al., (2003) relataram 50-60\%. Barreto et al., (2008) encontraram percentuais de C-HUM que variaram de 20,50 a $33,18 \%$ na profundidade de $0-10 \mathrm{~cm}$. Observaram-se também reduções de até $13,13 \%$ e no solo cultivado com amaranto, nessa profundidade. O regime hídrico não influenciou os percentuais de C-HUM nos solos cultivados com milheto e quinoa. Observa-se também que as espécies não influenciaram os percentuais de C-HUM em nenhum dos regimes hídricos, exceto no regime de $167 \mathrm{~mm}$, em que o maior valor foi observado no solo cultivado com amaranto. Na profundidade de 5-10 e 10-20, de maneira geral, os 
menores percentuais dessa fração foram observados no solo cultivado com milheto (Tabela 7.15).

Tabela 7.14: Desdobramento da interação da relação percentual (\%) entre carbono da fração humina e carbono orgânico total em função da planta de cobertura e do regime hídrico, nas profundidades de $0-5 \mathrm{~cm}$.

\begin{tabular}{cccc}
\hline $\begin{array}{c}\text { Regime } \\
\text { hídrico }\end{array}$ & Amaranto & Milheto & Quinoa \\
\cline { 2 - 4 } & & $0-5 \mathrm{~cm}$ & \\
$\mathbf{1 6 7}$ & $56,48 \mathrm{Aa}$ & $38,20 \mathrm{Ca}$ & $47,76 \mathrm{Ba}$ \\
$\mathbf{2 6 8}$ & $43,35 \mathrm{Ab}$ & $43,88 \mathrm{Aa}$ & $49,69 \mathrm{Aa}$ \\
$\mathbf{3 8 1}$ & $45,54 \mathrm{Ab}$ & $45,53 \mathrm{Aa}$ & $44,53 \mathrm{Aa}$ \\
$\mathbf{4 3 2}$ & $46,44 \mathrm{Ab}$ & $42,22 \mathrm{Aa}$ & $43,32 \mathrm{Aa}$ \\
\hline
\end{tabular}

Médias seguidas pelas mesmas letras, maiúsculas nas linhas e minúsculas nas colunas, não diferem entre si pelo teste de Tukey ao nível de $5 \%$.

Tabela 7.15: Relação percentual (\%) entre carbono da fração humina e carbono orgânico total em função da planta de cobertura e do regime hídrico, nas profundidades de 0-5.

\begin{tabular}{cccc}
\hline \multicolumn{4}{c}{$\mathbf{5 - 1 0}$ cm } \\
Planta de cobertura \\
Amaranto & Milheto & Quinoa & \\
$44,20 \mathrm{ab}$ & $42,55 \mathrm{~b}$ & $47,28 \mathrm{a}$ & \\
& & & \\
& Regime hídrico $(\mathrm{mm})$ & 381 & 432 \\
$48,10 \mathrm{a}$ & 268 & $44,69 \mathrm{ab}$ & $42,56 \mathrm{~b}$
\end{tabular}

$10-20 \mathrm{~cm}$

\begin{tabular}{cccc}
\hline \multicolumn{4}{c}{ Planta de cobertura } \\
Amaranto & Milheto & Quinoa & \\
$44,39 \mathrm{ab}$ & $42,87 \mathrm{~b}$ & $45,79 \mathrm{a}$ & \\
& & & \\
& Regime hídrico $(\mathrm{mm})$ & 381 & 432 \\
167 & 268 & $48,96 \mathrm{a}$ & $42,71 \mathrm{~b}$ \\
\hline $42,06 \mathrm{~b}$ & $43,66 \mathrm{~b}$ & &
\end{tabular}
nível de 5\%.

\section{Carbono da biomassa microbiana}

Os valores de C-mic variaram de 175,66 a 296,48; 98,25 a 199,22; e 32,41 a $120,30 \mathrm{mg} \mathrm{kg}^{-1}$ para as camadas de 0-5, 5-10 e 10-20 cm, respectivamente. Oliveira et al. (2016), avaliando a dinâmica de atributos microbiológicos do solo em diferentes sistemas de cultivo na região Centro Oeste, encontraram valores de CBM que variaram de 114,07 a 546,46 $\mathrm{mg} \mathrm{kg}^{-1}$. Apesar das camadas de solo não terem sido comparadas, observou-se 
tendência de redução dos teores de C-mic em profundidade. Tal fato pode estar relacionado à redução dos resíduos das culturas em profundidade (Santos et al., 2013). Os resíduos das plantas de cobertura servem de substrato para a atividade microbiana (Casali, 2012; Guimarães et al., 2013; Lima Filho et al., 2014; Ensinas et al., 2016)

Tabela 7.16 - Desdobramento da interação entre regime hídrico e plantas de cobertura referente ao carbono da biomassa microbiana ( $\mathrm{mg} \mathrm{kg}^{-1}$ de solo) nas profundidades de 0 5 e $5-10$ e $10-20 \mathrm{~cm}$.

\begin{tabular}{cccc}
\hline $\begin{array}{c}\text { Regime } \\
\text { hídrico } \\
(\mathrm{mm})\end{array}$ & Amaranto & Milheto & Quinoa \\
\cline { 2 - 4 } & & $0-5$ & \\
167 & $293,34 \mathrm{Aa}$ & $224,96 \mathrm{ABa}$ & $178,87 \mathrm{Bb}$ \\
268 & $244,37 \mathrm{Aa}$ & $216,33 \mathrm{Aa}$ & $230,59 \mathrm{Aab}$ \\
381 & $288,91 \mathrm{Aa}$ & $193,07 \mathrm{Ba}$ & $288,30 \mathrm{Aa}$ \\
432 & $265,50 \mathrm{Aa}$ & $175,66 \mathrm{Ba}$ & $296,48 \mathrm{Aa}$ \\
& & $5-10$ & $126,76 \mathrm{Ab}$ \\
167 & $193,12 \mathrm{Aa}$ & $139,55 \mathrm{Aa}$ & $173,91 \mathrm{Aa}$ \\
268 & $128,90 \mathrm{Ab}$ & $127,70 \mathrm{Aa}$ & $199,22 \mathrm{Aa}$ \\
381 & $115,13 \mathrm{Bb}$ & $123,39 \mathrm{Ba}$ & $124,27 \mathrm{Ab}$ \\
432 & $98,25 \mathrm{Ab}$ & $123,56 \mathrm{Aa}$ & $32,41 \mathrm{Bb}$ \\
& & $10-20$ & $106,11 \mathrm{Aa}$ \\
167 & $120,30 \mathrm{Aa}$ & $104,59 \mathrm{Aa}$ & $100,25 \mathrm{Aa}$ \\
268 & $54,19 \mathrm{Bb}$ & $111,67 \mathrm{Aa}$ & $119,34 \mathrm{Aa}$ \\
381 & $75,83 \mathrm{Ab}$ & $87,49 \mathrm{Aa}$ & \\
432 & $65,83 \mathrm{Cb}$ & $85,26 \mathrm{Ba}$ & $\mathrm{d}$
\end{tabular}

Médias seguidas pelas mesmas letras, maiúsculas nas linhas e minúsculas nas colunas, não diferem entre si pelo teste de Tukey ao nível de $5 \%$.

Analisando-se a camada de 0-5 cm, observa-se, de maneira geral, que o solo cultivado com milheto apresentou os menores teores de C-mic, exceto no regime de 268 $\mathrm{mm}$, que não houve diferença entre as espécies. Diferentes teores de C-mic em solo cultivado com diferentes espécies podem estar relacionados à quantidade e qualidade dos materiais vegetais adicionados ao solo (Ferreira et al., 2011; Fernandes et al., 2012; Duarte et al., 2014; Loureiro et al., 2016; Coser et al., 2016). O solo cultivado com amaranto e quinoa apresentaram os mesmos teores de $\mathrm{C}$-mic em todas os regimes estudados, exceto no regime de $167 \mathrm{~mm}$. O regime hídrico influenciou os teores de Cmic apenas no solo cultivado com quinoa, onde foi observado que em condições de baixa disponibilidade hídrica (regime 167mm), o C-mic foi reduzido em 40\%. A água é essencial para os microrganismos, para sua absorção de nutrientes e sua locomoção 
(Moreira e Siqueira, 2006). Por outro lado, Oliveira et al. (2016) encontraram maiores valores de C-mic em solo seco. Segundo os autores, condições desfavoráveis de umidade do solo conduzem a uma concorrência mínima entre a microbiota e as plantas, aumentando assim a população de microrganismos. Na profundidade de $5-10 \mathrm{~cm}$, as plantas de cobertura influenciaram os teores de C-mic apenas quando submetidas ao regime de $381 \mathrm{~mm}$, sendo os maiores valores observados no solo com quinoa.

O C-mic foi semelhante em todos os regimes hídricos no solo cultivado com milheto, já para o amaranto houve reduções de até 96,5\% no C-mic com o aumento da disponibilidade hídrica. $\mathrm{O}$ excesso de água no solo interfere em fatores como a aeração, pH da solução e pressão osmótica que pode reduzir a atividade dos microrganismos (Moreira e Siqueira, 2006). Na quinoa, os maiores valores de C-mic foram observados nas lâminas intermediárias (381 e 268 mm). Com relação à camada de 10-20 cm, o solo cultivado com amaranto apresentou as mesmas tendências da camada de 5-10 cm, havendo redução no C-mic com o aumento da lâmina de água adicionada ao solo. Houve a redução de $82 \%$ do C-mic nessa camada, ao se comparar o regime hídrico superior com o inferior. O solo cultivado com quinoa apresentou comportamento semelhante à camada de 0-5 cm, tendo o menor valor de C-mic no menor regime hídrico. O regime hídrico não influenciou o C-mic no solo cultivado com milheto.

Com relação aos percentuais de C-mic no COT, a interação foi significativa para as profundidades de 0-5 e 10-20 cm. Na profundidade de $5-10 \mathrm{~cm}$ não houve efeito de nenhum dos fatores. Os percentuais de C-mic no COT variaram de 0,59 a 1,35\% na profundidade de $0-5 \mathrm{~cm}$ e de 0,24 a $0,70 \%$ na camada de $10-20 \mathrm{~cm}$ (Tabela 7.17). Jenkinson e Ladd (1981) consideram que os valores do C-mic no solo, ocorrem entre de 1 a 4\% do COT. Perez et al., (2004) ao avaliarem o carbono da biomassa microbiana em solos cultivados com soja encontraram percentuais de C-mic em relação ao COT, entre 1,0 a 2,3\% na camada de $0,5 \mathrm{~cm}$ e 0,9 a 1,5\% na profundidade de $10-20 \mathrm{~cm}$, em função dos sistemas de preparo do solo. Já Mazzeto et al., (2016) ao avaliarem a atividade da biomassa microbiana no solo no Sudoeste da Amazônia encontraram valores iguais a 2,98, 3,05 e 4,08\% para áreas agrícolas, áreas nativas e pastagem respectivamente. Solos que exibem valores altos e baixos da relação C-mic/COT podem representar, respectivamente acúmulo ou perda de carbono no solo (Balota et al., 1998). Na profundidade de $0-5 \mathrm{~cm}$ o regime hídrico não influenciou os percentuais de C-mic no solo 
cultivado com quinoa e milheto. Já na profundidade de $10-20 \mathrm{~cm}$ houve aumento de até $0,5 \%$ no solo cultivado com quinoa.

Tabela 7.17: Desdobramento da interação da relação percentual (\%) entre carbono da biomassa microbiana e carbono orgânico total em função da planta de cobertura e do regime hídrico, nas profundidades de $0-5 \mathrm{~cm}$.

\begin{tabular}{cccc}
\hline $\begin{array}{c}\text { Regime } \\
\text { hídrico }\end{array}$ & \multicolumn{3}{c}{ Planta de cobertura } \\
\cline { 2 - 4 } & Amaranto & Milheto & Quinoa \\
\hline $\mathbf{1 6 7}$ & $1,35 \mathrm{Aa}$ & $0-5 \mathrm{~cm}$ & $0,84 \mathrm{Ba}$ \\
$\mathbf{2 6 8}$ & $0,87 \mathrm{Ab}$ & $0,82 \mathrm{Ba}$ & $0,89 \mathrm{Aa}$ \\
$\mathbf{3 8 1}$ & $1,07 \mathrm{Aab}$ & $0,75 \mathrm{Aa}$ & $1,05 \mathrm{Aa}$ \\
$\mathbf{4 3 2}$ & $0,98 \mathrm{Ab}$ & $0,68 \mathrm{Ba}$ & $1,03 \mathrm{Aa}$ \\
& & $0,59 \mathrm{Ba}$ & $0,20 \mathrm{Bb}$ \\
$\mathbf{1 6 7}$ & $0,67 \mathrm{Aa}$ & $10-20 \mathrm{~cm}$ & $0,65 \mathrm{Aa}$ \\
$\mathbf{2 6 8}$ & $0,31 \mathrm{Bbc}$ & $0,58 \mathrm{Aa}$ & $0,67 \mathrm{Aa}$ \\
$\mathbf{3 8 1}$ & $0,44 \mathrm{Bb}$ & $0,66 \mathrm{Aa}$ & $0,70 \mathrm{Aa}$ \\
$\mathbf{4 3 2}$ & $0,24 \mathrm{Cc}$ & $0,55 \mathrm{Aba}$ & $0,48 \mathrm{Ba}$ \\
\hline
\end{tabular}

Médias seguidas pelas mesmas letras, maiúsculas nas linhas e minúsculas nas colunas, não diferem entre si pelo teste de Tukey ao nível de $5 \%$.

\subsection{CONCLUSÒES}

O solo cultivado com milheto apresentou os maiores teores de COT e as plantas de cobertura cultivadas em condições de maior disponibilidade hídrica propiciaram aumento nos teores de $\mathrm{C}$ das frações húmicas do solo.

O aumento da disponibilidade hídrica para as plantas provoca aumento e redução no carbono microbiano nas três camadas de solo, dependendo da espécie utilizada.

\subsection{REFERÊNCIAS BIBLIOGRÁFICAS}

ARAUJO, L.G; FIGUEIREDO, C.C; BORGES, I.B; RAMOS, M.L.G; ROCHA, O.C; GUERRA, A.F. Organic matter fractions in soil under coffee with split applications of phosphorus and water regimes. Revista Brasileira de Engenharia Agrícola e Ambiental, v.18, n.10, p. 1017-1022, 2014.

ASSIS, C.P.; JUCKSCH, I.; SÁ MENDONÇA, E.; NEVES, J.C.L. Carbono e nitrogênio em agregados de Latossolo submetido a diferentes sistemas de uso e manejo. Pesquisa Agropecuária Brasileira, v.41, p.1541-1550, 2006. 
BARROS, D.L; GOMIDE, P.H.L; CARVALHO, G.J. Plantas de cobertura e seu efeito na cultura em sucessão. Biosci. J, Uberlândia, v. 29, n. 2, p. 308-318, 2013.

BARRETO, P.A.B; GAMA-RODRIGUES, E.F; GAMA-RODRIGUES, A.C. Carbono das frações da matéria orgânica em solos sob plantações de eucalipto de diferentes idades. Scientia Florestalis, Piracicaba, v. 42, n. 104, p. 581-590, 2014.

BARRETO, A.C; FREIRE, M.B.G.S; NACIF, P.G.S; ARAUJO, Q.R; FREIRE, F.J; INACIO, E.S.B. Fracionamento físico e químico do carbono orgânico total em um solo de mata submetido a diferentes usos. Revista Brasileira de Ciencias do Solo. V.32, p.1471-1478, 2008.

BALOTA, E. L., COLOZZI-FILHO, A., ANDRADE, D. S. E HUNGRIA, M. Biomassa microbiana e sua atividade em solos sob diferentes sistemas de preparo e sucessão de culturas. Revista Brasileira de Ciência do Solo, 22, 641-649, 1998.

BENITES, V.M.; MADARI, B.; MACHADO, P.L.O.A. Extração e fracionamento quantitativo de substâncias húmicas do solo: um procedimento simplificado de baixo custo. Rio de Janeiro: Embrapa Solos, 2003. 7p. (Embrapa Solos. Comunicado técnico, 16).

CAMPOS, L.P; LEITE, L.F.C; MACIEL, G.A; BRASIL, E.L; IWATA, B.F. Estoque e frações do carbono orgânico em latossolo amarelo submetido a diferentes sistemas de manejo. Pesq. Agropec. Bras. V.48, n.3, p. 304-312, 2013.

CARVALHO AM, COELHO MC, DANTAS RA, FONSECA OP, GUIMARÃES JUNIOR R, FIGUEIREDO CC. Chemical composition of cover plants and its effect on maize yield in no-tillage systems in the Brazilian savanna. Crop Past Sci. 63:1075-1081, 2012.

CASALI CA. Sistemas de culturas sob diferentes manejos em longa duração alteram as formas de fósforo do solo [tese]. Santa Maria: Universidade Federal de Santa Maria; 2012.

CARMO, F. F.; FIGUEIREDO, C. C.; RAMOS, M. L. G.; VIVALDI, L. J.; ARAÚJO, L. G. Frações granulométricas da matéria orgânica em Latossolo sob plantio direto com gramíneas. Bioscience Journal, v.28, p.420-431, 2012.

COSTA, A. R.; SATO, J. H.; RAMOS, M. L. G.; FIGUEIREDO, C. C. SOUZA, J. P. ROCHA, O. C.; GUERRA, A. F. Microbiological properties and oxidizable organic carbon fractions of an Oxisol under coffee with split phosphorus applications and irrigation regimes. Revista Brasileira de Ciência do Solo, v.37, p.55-65, 2013.

COSER, T.R; RAMOS, M.L.G; FIGUEIREDO, C.C; CARVALHO, A.M; CAVALCANTE, E; MOREIRA, M.K.R; ARAUJO, P.S.M; OLIVEIRA, S.A; Soil microbiological properties and availabe nitrogen for corn in monoculture and intercropped with forage. Pesq. Agropec. Bras. V.51, n.9, p. 1660-1667, 2016.

CRUSCIOL CAC, MATEUS GP, NASCENTE AS, MARTINS PO, BORGHI E, PARIZ CM. An innovative crop-forage intercrop system: early cycle soybean cultivars and palisadegrass. Agronomy Journal. 104: 1085-95, 2012 
DUARTE, I.B; GALLO, A.S; GOMES, M.S; GUIMARAES, N.F; ROCHA, D.P; SILVA, R.F. Plantas de cobertura e seus efeitos na biomassa microbiana do solo. Acta iguazu, cascavel, v.3, n.2, p. 150-165, 2014.

DENEF, K. et al. Does long-term center-pivot irrigation increase soil carbon stocks in semi-arid agroecosystems Geoderma, v.145, p,121-129, 2008.

ENSINAS SC, SERRA AP, MARCHETTI ME, SILVA EF, PRADO EAF, LOURENTE ERP, ALTOMAR PH, POTRICH DC, MARTINEZ MA, CONRAD VA, JESUS MV, KADRI TC. Cover crops effect on soil organic matter fractions under no till system. Australian Journal of Crop Science. V. 10; p 503-512, 2016.

FERNANDES, M. M.; CARVALHO, M. G. C.; ARAÚJO, J. M. R.; MELO, F. R.; SILVA, C. A.; SAMPAIO, F. M. T.; LOBATO, M. G. R. Matéria orgânica e biomassa microbiana em plantios de eucalipto no Cerrado Piauiense. Revista Floresta e Ambiente, v. 19, n. 4, p. 453-459, 2012.

FERREIRA, E.P. de B.; WENDLAND, A.; DIDONET, A.D. Microbial biomass and enzyme activity of a Cerrado Oxisol under agroecological production system. Bragantia, v.70, p.899-907, 2011.

FIGUEIREDO, C. C.; I; RESCK, D. V. S.; CARNEIRO, M. A. C. Labile and stable fractions of soil organic matter under management systems and native cerrado. Revista Brasileira de Ciência do Solo v.34, p.907- 916, 2010.

FONTANA, A.; PEREIRA, M.G.; LOSS, A.; CUNHA, T.J.F.; SALTON, J.C. Atributos de fertilidade e frações húmicas de um Latossolo Vermelho no Cerrado. Pesquisa Agropecuária Brasileira, v.41, p.847-853, 2006.

GUIMARÃES，D.V; GONZAGA，M.I.S; SILVA，T.O; SILVA，T.L; DIAS，N.S; MATIAS, M.I.S. Soil organic matter pools and carbono fractions in soil under diferente land uses. Soil e Tillage Research, v. 126, p. 177-182, 2013.

GUARESCHI, R.F.; PEREIRA, M.G.; PERIN, A. Frações da matéria orgânica em áreas de Latossolo sob diferentes sistemas de manejo no Cerrado do Estado de Goiás. Semina: Ciências agrárias, v.34, p.2615-2628, 2013.

JENKINSON, E. S. E LADD, J. N. (1981). Microbial biomass in soil measurement and turnover. In E. A. Paul e J. N. Ladd (Eds.), Soil biochemistry (p. 415-471). New York: Marcel Dekker.

LEITE, L. F. C. et al. Decomposição e liberação de nutrientes de resíduos vegetais depositados sobre Latossolo Amarelo no Cerrado Maranhense. Revista Ciência Agronômica, v. 41, n. 1, p. 29-35, 2010.

LIMA FILHO OF, AMBROSANO EJ, ROSSI F, CARLOS JAD, Organizadores. Adubação verde e plantas de cobertura no Brasil: fundamentos e prática. Brasília, DF: Embrapa; 2014. v.1. 
LOUREIRO, D.C; POLLI, H; AQUINO, A.M; SÁ, M.M.F; GUERRA, J.G.M. Influencia do uso do solo sobre a conservação do carbono da biomassa microbiana em sistemas orgânicos de produção. Revista Brasileira De Agroecologia, v.11, n.1, p. 1-10, 2016.

LOSS, A.; COUTINHO, F. S.; PEREIRA, M. G.; SILVA, R. A. C.; TORRES, J. L. R.; RAVELLI NETO, A. Fertilidade e carbono total e oxidável de latossolo de cerrado sob pastagem irrigada e de sequeiro. Ciência rural, v.43, p.426-432, 2013.

LEITE, L.F.C.; MENDONÇA, E.S.; NEVES, J.C.L.; MACHADO, P.L.O.A. \& GALVÃO, J.C.C. Estoques totais de C orgânico e seus compartimentos em Argissolo sob floresta e sob milho cultivado com adubação mineral e orgânica. Revista Brasileira de Ciencias do Solo , 27:821-832, 2003.

LOSS, A.; MORAES, A.G. de L.; PEREIRA, M.G.; SILVA, E.M.R. da; ANJOS, L.H.C. dos. Carbono, matéria orgânica leve e frações oxidáveis do carbono orgânico sob diferentes sistemas de produção orgânica. Comunicata Scientiae, v.1, p.57-64, 2010a.

MATEI, G.; MATEI, S.; MOCANU, V.; SECELEANU, I.; COTET,, V.; DUMITRU, S. Study on microbial communities and soil organic matter in irrigated and non-irrigated vertisol from Boianu. Soil Forming Factors and Processes from the Temperate Zone, v.11, p.1-8, 2012.

MOREIRA, F.M.S. E SIQUEIRA, J.O. Microbiologia e bioquímica do solo. Editora UFLA, 625 p., 2006.

MAZZETO, A.M; CERRI, C.E.P; FEIGL, B.J; CERRI, C.C. Atividade da biomassa microbiana do solo alterada pelo uso da terra no sudoeste da Amazônia. Bragantia, 2016.

MELO, G.B; PEREIRA, M.G; PERIN, A; GUARESHI, R.F; SOARES, P.F.C. Estoques e frações da matéria orgânica do solo sob os sistemas plantio direto e convencional com repolho. Pesquisa Agropecuaria Brasileira, v. 51, n. 9, p 1511-1519, 2016.

NASCENTE AS, CRUSCIOL C.A.C. Cover crops and herbicide timing management on soybean yield under no-tillage system. Pesquisa Agropecuária Brasileira. 47: 187-92, 2012.

OLIVEIRA, W.R.D; RAMOS, M.L.G; CARVALHO, A.M; COSER, T.R; SILVA, A.M.M; LACERDA, M.M; SOUZA, K.W; MARCHAO, R.L; VILELA, L; PULRONIK, K. Dynamics of soil microbiological attributes under integrated production systems, continuous pasture, and native cerrado. Pesquisa Agropecuária Brasileira, Brasília, v.51, n.9, p.1501-1510, 2016.

PARTELli, F. L.; BUSATO, J. G VIEIRA, H. D.; VIANA, A. P.; CANELLAS, L. P. Qualidade da matéria orgânica e distribuição do fósforo no solo de lavouras orgânicas de café Conilon. Ciência Rural, v.39, p.2065-2072, 2009.

PEREZ, K.S.S; RAMOS, M.L.G; McMANUS, C. Carbono da biomassa microbiana em solo cultivado com soja sob diferentes sistemas de manejo nos cerrados. Pesquisa Agropecuária Brasileira, Brasilia, v.39, n.6, p. 566-573, 2004. 
PRIMO, D.C; MENEZES, R.S.C; SILVA, T.O. Substâncias húmicas da matéria orgânica do solo: Uma revisão das técnicas analíticas e estudos no nordeste brasileiro. Scientia Plena, vol. 7, n. 5, 2011.

ROSSI, C.Q; PEREIRA, M.G; GIACOMO, S.G; BETTA, M; POLIDORO, J.C. Frações húmicas da matéria orgânica do solo cultivado com soja sobre palhada de braquiária e sorgo. Bragantia, Campinas, v.70, n.3, p. 622-630, 2011.

ROSSI, C.Q.; PEREIRA, M.G.; GIÁCOMO, S.G.; BETTA, M.; POLIDORO, J.C. Frações lábeis da matéria orgânica em sistema de cultivo com palha de braquiária e sorgo. Revista Ciência Agronômica, Fortaleza, v.43, n.1, p.38-46, 2012a.

ROSA, D.M; NOBREGA, L.H.M; MAULI, M.M; LIMA, G.P; PACHECO, F.P. Substâncias húmicas do solo cultivado com plantas de cobertura em rotação com milho e soja. Revista Ciência Agronômica, Fortaleza, v.48, n.2, p.22-230, 2017.

SANTOS, I.L. dos; CAIXETA, C.F.; SOUSA, A.A.T.C. de; FIGUEIREDO, C.C. de; RAMOS, M.L.G.; CARVALHO, A.M. de. Cover plants and mineral nitrogen: effects on organic matter fractions in an oxisol under no-till in the cerrado. Revista Brasileira de Ciência do Solo, v.38, p.1874-1881, 2014.

SILVA, A.N; FIGUEIREDO, C.C; CARVALHO, A.M; SOARES, D.S; SANTOS, D.C.R; SILVA, V.G. Effects of cover crops on the physical protection of organic matter and soil aggregation. Australian Journal of crop science. V.10, n.12, p.1623-1629, 2016.

SILVA, A. G; CRUSCIOL, C.A.C; SORATTO, R.P; COSTA, C.H.M; FERRARI NETO, J. Produção de fitomassa e acúmulo de nutrientes por plantas de cobertura e cultivo da mamona em sucessão no sistema plantio direto. Ciência Rural, v. 40, n. 10, p. 20922098, 2010.

SILVA, I.R.; MENDONÇA, E.S. Matéria orgânica do solo. In: NOVAIS, R.F.; ALVAREZ V., V.H.; BARROS, N.F. de; FONTES, R.L.F.; CANTARUTTI, R.B.; NEVES, J.C.L. (Ed.). Fertilidade do solo. Viçosa: Sociedade Brasileira de Ciência do Solo, p.275-374, 2007.

SOUZA, G.P; FIGUEIREDO, C.C; SOUZA, D.M.G. Soil organic matters as affected by management systems, phosphate fertilization, and cover crops. Pesquisa Agropecuária Brasileira. V.51, n.9, p.1668-1676, 2016

SOUZA, W.J.O. \& MELO, W.J. Matéria orgânica de um Latossolo submetido a diferentes sistemas de produção de milho. Revista Brasileira de Ciencias do Solo, 27:1113-1122, 2003.

VARGAS, L.K.; SCHOLLES, D. Biomassa microbiana e produção de C-CO2 e N mineral de um Podzólico Vermelho-Escuro submetido a diferentes sistemas de manejo. Revista Brasileira de Ciência do Solo, Viçosa, v.24, p.35-42, 2000.

ZHONGKUI, L.; WANG, E.; SUN, O.J. Soil carbon change and its responses to agricultural practices in Australian agro-ecosystems: a review and synthesis. Geoderma, v.155, p.211-223, 2010. 
